\title{
ipen
}

INSTITUTO DE PESQUISAS ENERGÉTICAS E NUCLEARES

Autarquia associada à Universidade de São Paulo

\section{EFEITO DA RADIAÇÃO IONIZANTE NA FORMAÇÃO DE VOLÁTEIS EM CHÁS DA PLANTA Camellia sinensis (L)}

\section{GUSTAVO BERNARDES FANARO}

Dissertação apresentada como parte dos requisitos para obtenção do grau de Mestre em Ciências na área de Tecnologia Nuclear Aplicações.

Orientadora:

Dra. Anna Lucia C. H. Villavicencio

SÃO PAULO 


\section{ipen}

INSTITUTO DE PESQUISAS ENERGÉTICAS E NUCLEARES

Autarquia associada à Universidade de São Paulo

\section{EFEITO DA RADIAÇÃO IONIZANTE NA FORMAÇÃO DE VOLÁTEIS EM CHÁS DA PLANTA Camellia sinensis (L)}

\section{GUSTAVO BERNARDES FANARO}

Dissertação apresentada como parte dos requisitos para obtenção do grau de Mestre em Ciências na área de Tecnologia Nuclear Aplicações.

Orientadora:

Dra. Anna Lucia C. H. Villavicencio

SÃO PAULO 


\section{A osmeuspais, A lberto eL eda. $P$ or todo apoio quesompre recedi.}




\section{AGRADECIMENTOS}

À Dra. Anna Lucia C. H. Villavicencio pela confiança e orientação que começou desde a iniciação científica, me preparando para a conclusão deste projeto e para vida;

Ao IPEN, especialmente ao Centro de Tecnologia das Radiações, representado pelo Dr. Wilson Aparecido Parejo Calvo, gerente do CTR, e pela Dra. Margarida Hamada, chefe de divisão de pesquisa e desenvolvimento do CTR, pelo constante apoio e prédisposição em ajudar e buscar soluções;

Ao Dr. Eduardo Purgatto pela valiosa colaboração e ensinamentos, assim como por disponibilizar seu laboratório e equipamentos, senão seria impossível realizar esta pesquisa;

Aos engenheiros Elizabeth Somessari e Carlos Gaia da Silveira, pelo constante auxílio no processamento por irradiação das amostras no Gammacell;

Ao Marcos e à Claudia pela ajuda nos assuntos administrativos;

Aos colegas do laboratório, pela valorosa ajuda na realização deste trabalho e pelos vários momentos de descontração: Msc. Michel, Camilo, Priscila, Renato, Msc. Débora, Thaíse, Renata, Vera, Vladimir, Amanda e Helbert;

Aos demais profissionais e bolsistas do Centro de Tecnologia das Radiações, pelo convívio harmonioso e enriquecedor;

Ao CNPq, pelo auxílio financeiro;

Por todos aqueles, que no momento não me recordo seus nomes, mas contribuíram tanto nesse trabalho, quanto na minha formação. 


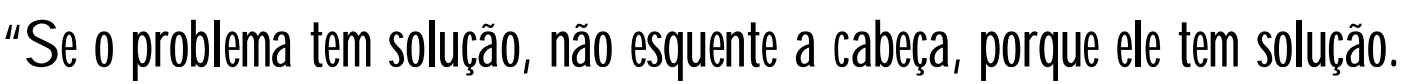
Seopddẹa rz̃otensduçãa rãoequetea chara prquederz̃otem solução". 
“A ciêniaéuna cisanarailhosa, dscequeCOVêrãoterhaqugarher avich compa".

\author{
Albet Einstén
}

nas "Saubảilèroerãodkistonund" 


\title{
EFEITO DA RADIAÇÃO IONIZANTE NA FORMAÇÃO DE VOLÁTEIS EM CHÁS DA PLANTA Camellia sinensis (L)
}

\section{GUSTAVO BERNARDES FANARO}

\begin{abstract}
RESUMO
O objetivo desse estudo foi avaliar os efeitos da radiação na formação de voláteis nos chás branco, verde, oolong e preto. As amostras foram irradiadas em temperatura ambiente na fonte de ${ }^{60}$ Co Gammacel 220 (A.E.C. Ltda) nas doses de 0, 5, 10, 15 e 20kGy. Os compostos orgânicos voláteis foram extraídos por hidrodestilação e os extratos foram separados e identificados por análise em cromatografia a gás acoplado ao espectrômetro de massas (CG/EM). Os resultados mostraram que a formação de voláteis foi diretamente proporcional ao aumento de dose de radiação. O chá branco foi o chá que mostrou sofrer menor influência da radiação ionizante, pois $37,86 \%$ dos compostos foram estáveis a todas as doses de radiação e formou 47,53\% de novos compostos após a irradiação. O chá verde foi o chá que sofreu a maior influência dos efeitos da radiação na formação de novos compostos, gerando um aumento de $66,12 \%$ de voláteis identificados em relação à amostra controle e apenas $21,77 \%$ dos voláteis encontrados naturalmente foram resistentes a todas as doses de radiação. O chá oolong apesar de sofrer um tratamento enzimático parcial, foi o segundo chá que sofreu a menor interferência da radiação no aumento da formação de novos voláteis. Nesse chá foi possível detectar 49,59\% de novos compostos após a irradiação e 30,08\% dos compostos encontrados naturalmente também foram encontrados depois da irradiação. O chá preto foi o segundo chá que sofreu a maior interferência da radiação na formação de novos voláteis $(60,94 \%)$, porém foi o chá onde se obteve a menor quantidade de compostos estáveis à radiação. Apenas 17,97\% do total de compostos identificados não foram degradados quando empregado à radiação ionizante.
\end{abstract}

Palavras chaves: Chá branco, Chá verde, Chá oolong, Chá preto, Irradiação, Compostos Orgânicos Voláteis. 


\title{
IONINZING RADIATION EFFECTS ON VOLATILES FORMATION IN Camellia sinensis (L) TEAS
}

\section{GUSTAVO BERNARDES FANARO}

\begin{abstract}
The aim of this study was to evaluate the effects of radiation on volatile formation in white, green, oolong and black teas. Samples were irradiated in room temperature at ${ }^{60} \mathrm{Co}$ source Gammacell 220 (A.E.C. Ltda) at doses of 0, 5, 10, 15 and 20kGy. The volatiles organic compound was extracted by hydrodestilation and the extract was separated and identified by gas chromatography-mass spectrometry (GC-MS) analysis. The results show that the volatiles formations are directly proportional to the increase of radiation dose. The white tea showed less influence of ionizing radiation, as $37.86 \%$ of the compounds were stable at all doses of radiation and formed $47.53 \%$ of new compounds after irradiation. The green tea was the tea that has the greatest influence of radiation effects, increasing $66.12 \%$ of volatiles identified in relation to the control sample and only $21.77 \%$ of volatiles found naturally were resistant to all doses of radiation. The oolong tea, despite suffering a partial enzymatic treatment, was the second tea that has least interference of radiation in increasing the formation of new volatile. From this tea, was able to detect $49.59 \%$ of new compounds after irradiation and $30.08 \%$ of the compounds found naturally were also found after irradiation. The black tea has the second greatest influence of radiation on formation of new volatile (60.94\%) and only $17.97 \%$ of all identified compounds were not degraded after radiation.
\end{abstract}

Keywords: White tea, Green tea, Oolong tea, Black tea, Irradiation, Volatiles Organic Compounds. 


\section{SUMÁRIO}

PÁGINA

1 INTRODUÇÃO

2 OBJETIVOS............................................................................................................

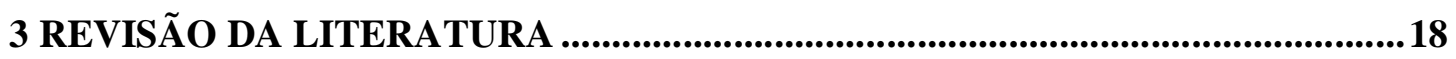

3.1 Chá

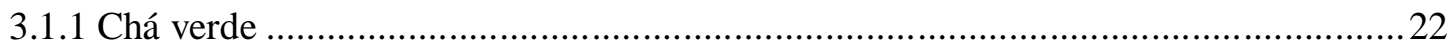

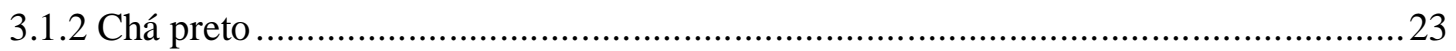

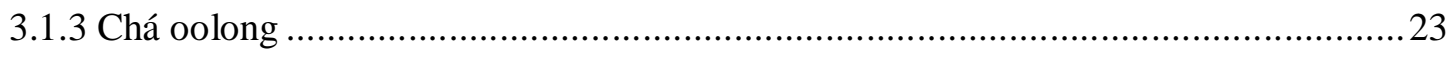

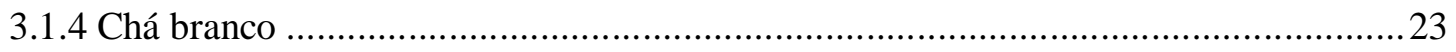

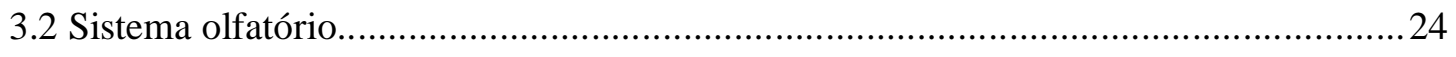

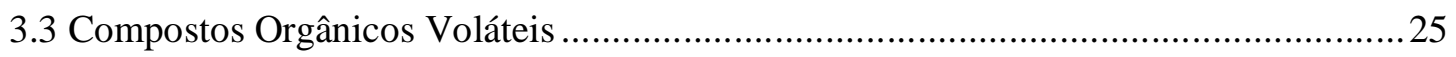

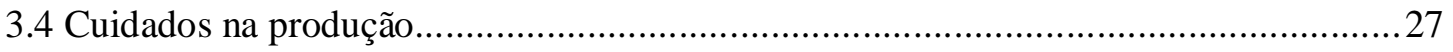

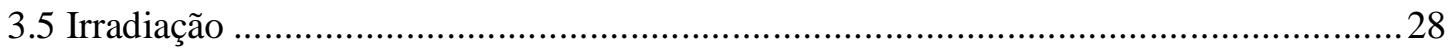

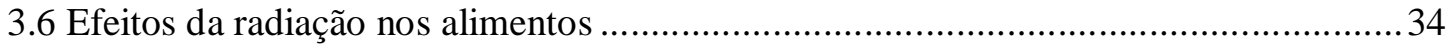

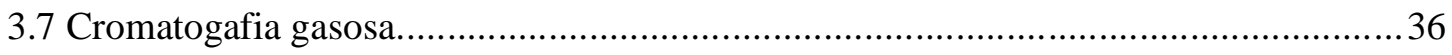

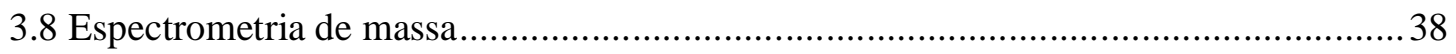

3.9 Cromatografia gasosa acomplado ao espectrômetro de massa ……………………….... 40

4 MATERIAIS E MÉTODOS ................................................................................42

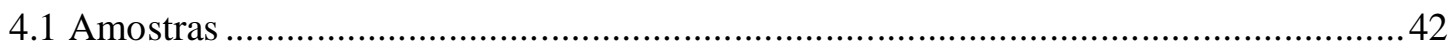

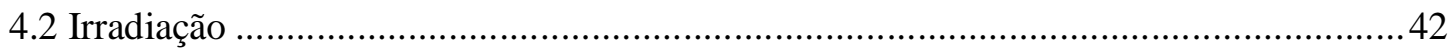

4.3 Extração dos compostos voláteis................................................................................ 42

4.4 Separação dos compostos orgânicos voláteis (COV) ………………………………....4

4.5 Identificação dos compostos voláteis ........................................................................ 43

4.6 Quantificação dos compostos voláteis...................................................................... 43

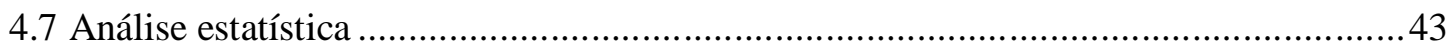

5 RESULTADOS E DISCUSSÃO .................................................................................45

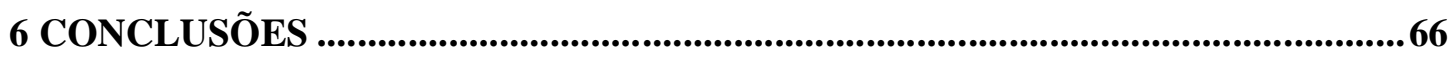

7 TRABALHOS FUTUROS........................................................................................................67 
8 ANEXO A

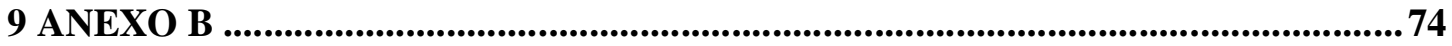

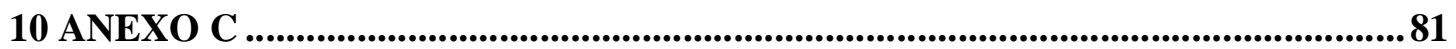

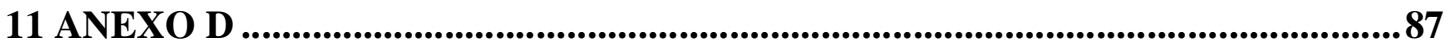

REFERÊNCIAS BIBLIOGRÁFICAS ..........................................................99 


\section{LISTA DE FIGURAS}

PÁGINA

FIGURA 1 - Aspectos gerais da árvore C. sinensis

FIGURA 2 - Esquema de obtenção dos diferentes tipos de chá da planta $C$. sinensis ........ 24

FIGURA 3 - Símbolo internacional para alimentos irradiados ......................................... 32

FIGURA 4 - Esquema geral de um cromatógrafo a gás.................................................... 38

FIGURA 5 - Esquema geral de um espectrômetro de massas ............................................ 39

FIGURA 6 - Esquema da ionização por elétrons....................................................... 40

FIGURA 7 - Esquema de um cromatógrafo a gás acoplado a um espectrômetro de

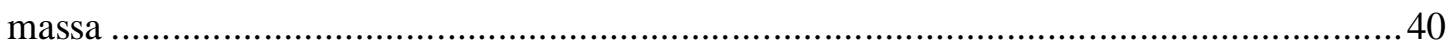

FIGURA 8 - Número de total de compostos voláteis identificados, após a irradiação, nos diferentes tipos de chá

FIGURA 9 - Porcentagem de compostos voláteis identificados no chá branco nas diferentes doses de radiação .46

FIGURA 10 - Número de COV que possuem odores agradáveis e desagradáveis encontrados naturalmente no chá branco. 48

FIGURA 11 - Número de COV que possuem odores agradáveis e desagradáveis encontrados no chá branco irradiado com diversas doses

FIGURA 12 - Distribuição da quantidade de dez COV, em $\mu \mathrm{g} / 100 \mathrm{~g}$ de chá branco, nas diferentes doses de radiação

FIGURA 13 - Análise de componentes principais do chá branco irradiado com diferentes doses .50

FIGURA 14 - Porcentagem de compostos voláteis identificados no chá verde nas diferentes doses de radiação .51

FIGURA 15 - Número de COV que possuem odores agradáveis e desagradáveis encontrados naturalmente no chá verde

FIGURA 16 - Número de COV que possuem odores agradáveis e desagradáveis encontrados no chá verde irradiado com diversas doses

FIGURA 17 - Distribuição da quantidade de cinco COV, em $\mu \mathrm{g} / 100 \mathrm{~g}$ de chá verde, nas diferentes doses de radiação 
FIGURA 18 - Análise de componentes principais do chá verde irradiado com diferentes

doses

FIGURA 19 - Porcentagem de compostos voláteis identificados no chá oolong nas diferentes doses de radiação

FIGURA 20 - Número de COV que possuem odores agradáveis e desagradáveis encontrados naturalmente no chá oolong

FIGURA 21 - Número de COV que possuem odores agradáveis e desagradáveis encontrados no chá oolong irradiado com diversas doses. .57

FIGURA 22 - Distribuição da quantidade de sete COV, em $\mu \mathrm{g} / 100 \mathrm{~g}$ de chá oolong, nas diferentes doses de radiação .58

FIGURA 23 - Análise de componentes principais do chá verde irradiado com diferentes doses 59

FIGURA 24 - Porcentagem de compostos voláteis identificados no chá preto nas diferentes doses de radiação.

FIGURA 25 - Número de COV que possuem odores agradáveis e desagradáveis encontrados naturalmente no chá preto

FIGURA 26 - Número de COV que possuem odores agradáveis e desagradáveis encontrados no chá preto irradiado com diversas doses.

FIGURA 27 - Distribuição da quantidade de nove COV, em $\mu \mathrm{g} / 100 \mathrm{~g}$ de chá preto, nas diferentes doses de radiação

FIGURA 28 - Análise de componentes principais do chá preto irradiado com diferentes doses 63

FIGURA 29 - Quantidade de cafeína, em $\mu \mathrm{g} / 100 \mathrm{~g}$ de chá, nos diferentes tipos de chá irradiados 


\section{INTRODUÇÃO}

O chá é uma das bebidas mais consumidas no mundo. Anteriormente, seu consumo concentrava-se em países da Ásia e Europa, panorama que vem mudando ao longo dos últimos anos. O crescente interesse pela bebida deve-se a inúmeros estudos que a mostram como fonte de antioxidantes e a relação inversa entre seu consumo e o risco de doenças degenerativas como câncer e doenças do coração (Matsubara e Rodriguez-Amaya, 2006a,b; Saito et al., 2006; Santana-Rios et al., 2001b).

Segundo uma lenda chinesa, o chá foi descoberto acidentalmente por um imperador há 4.000 anos, enquanto há relatos que os chineses consomem essa bebida desde 3.000 A.C. (Ferrara et al., 2001).

Chá é definido como produto constituído de uma ou mais partes de espécie(s) vegetal(is) inteira(s), fragmentada(s) ou moída(s), podendo ser ou não fermentado, tostada(s), constantes de Regulamento Técnico de Espécies Vegetais para o Preparo de Chás (Brasil, 2005).

Nos últimos anos, houve um grande aumento no consumo de chás de todos os tipos, principalmente de chás provenientes da planta Camellia sinensis (L) O. Kuntze, uma planta da família Theaceae, que dependendo do beneficiamento dado pela indústria, pode dar origem a diferentes tipos de chás. Os mais comuns são o chá branco, verde, oolong e preto (Prado et al., 2005; Santana-Rios et al., 2001a).

Esse aumento no consumo é devido ao fato de chás de $C$. sinensis possuírem altos teores de antioxidantes, o que significa que podem ter efeitos benéficos tanto na conservação de alimentos, quanto na preservação da saúde humana quando presentes regularmente na dieta (Becker et al., 2004), podendo ser considerado um alimento funcional.

Entre os antioxidantes presentes na $C$. sinensis os mais ativos e freqüentemente encontrados são os compostos fenólicos, como as catequinas (C), epigalocatequina (EGC), 
epigalocatequina galato (EGCG), epicatequina (EC), epicatequina galato (ECG); teaflavinas e flavonóides como a miricetina, quercetina e o kaempferol (Bianchi e Antunes, 1999).

Os antioxidantes promovem esses benefícios, pois atuam por meio de um ou mais dos seguintes mecanismos: indução de várias enzimas que são ativadas na via metabólica de drogas, como no metabolismo de inativação de substâncias carcinogênicas e mutagênicas, seqüestro de espécies reativas de oxigênio e óxido nítrico, no sistema de checagem das células quando estas estão em divisão e no processo de apoptose (Dreosti et al., 1997; Mukhtar e Ahmed, 1999; Tijburg et al., 1997; Yang et al., 2000).

Durante séculos, a humanidade procura formas de conservar melhor e por mais tempo os alimentos que consomem. A preservação e o armazenamento desses alimentos a baixa temperatura estão entre as técnicas de preservação mais antigas que se conhece. Já uma das técnicas mais recentes de preservação é o tratamento dos alimentos por radiação gama (Chmielewski e Haji-Saeid, 2004; Farkas, 2006; Masefield, 2004).

Os alimentos são irradiados com as mais diversas finalidades tais como: desinfecção de agentes causadores de doenças, prolongar o tempo de vida útil do produto, inibir o brotamento, inativação de organismos que degradam o alimento, retardo da maturação entre outros (Diehl, 2002; Villavicencio et al., 2007). A característica da radiação de alta energia é causar ionização no meio em que é absorvida, ou seja, é capaz de remover elétrons de seus orbitais, seja em átomos ou moléculas (ICGFI, 1995).

O processo de irradiação pode inibir a divisão de células vivas, como microrganismos, promovendo uma alteração em sua estrutura molecular (Brasil, 2001). As células vegetativas são, geralmente, mais sensíveis à radiação ionizante do que bolores e leveduras que, por sua vez, são mais resistentes do que os esporos bacterianos (Diehl, 1995; Monk et al., 1995).

A radiação ionizante quando é absorvida por um material biológico, pode ter ação direta ou indireta sobre o material que recebeu este processamento. O mecanismo primário no qual a radiação destrói os microrganismos é dado pela quebra das fitas duplas de DNA causando inativação dessa célula. Esse processo é dominante quando esporos secos de microorganismos são irradiados. Já o efeito indireto é ocasionado pela interação 
da radiação com a molécula de água, o que acaba por gerar os chamados radicais livres. Estes irão interagir com outros constituintes do material biológico tratado com radiação, de maneira similar aos que reagem nos alimentos. Esse efeito é importante em células vegetais, que possuem uma abundante quantidade de água (Hayes et al., 1995; Monk et al., 1995; Morehouse, 1998).

Esses radicais livres são produzidos em quantidades pequenas, mesmo quando são utilizadas doses altas. A interação da água com o oxigênio pode aumentar intensamente a produção desses radicais, principalmente o peróxido de hidrogênio $\left(\mathrm{H}_{2} \mathrm{O}_{2}\right)$ que é conhecido por ser um agente oxidante (Diehl, 2002).

Por muito tempo os alimentos irradiados foram estudados, até que se chegou à conclusão que os alimentos submetidos ao processamento por radiação, cuja dose utilizada não interferiu nas propriedades sensoriais e na composição do alimento, do ponto de vista toxicológico, são seguros para o consumo humano (Delincée e Pool-Zobel, 1998; WHO, 1994).

Diversos trabalhos têm empregado a irradiação em plantas medicinais e em fitoterápicos com o objetivo de controlar o crescimento microbiológico, inclusive na $C$. sinensis. Alguns deles avaliaram as características fito-químicas, outros a colorimetria e alguns trabalhos verificaram a atividade antioxidante dessas espécies vegetais após a irradiação, porém nenhum trabalho em relação à formação de voláteis foi realizado em $C$. sinensis irradiadas.

Para o consumidor, a aceitabilidade de um determinado produto é diretamente proporcional à quantidade de "flavor" (aroma e sabor) que esse produto contém. Apesar dos compostos voláteis representarem uma pequena quantidade na composição de ervas, eles possuem alto impacto no "flavor" do produto final (Rawat et al., 2007). No caso de chás, como as de $C$. sinensis, o "flavor" determina a qualidade do produto e, portanto, seu preço de mercado (Machado et al., 2007), evidenciando assim, a importância de oferecer um produto seguro, do ponto de vista microbiológico, que promova o bem-estar e que atenda as expectativas dos consumidores. 


\section{OBJETIVOS}

- Analisar a formação de compostos voláteis da planta Camellia sinensis na forma de:

$>$ Chá verde

$>$ Chá preto

$>$ Chá oolong

$>$ Chá branco

submetidos ao tratamento por radiação ionizante com diferentes doses.

- Descrever os odores encontrados naturalmente e dos novos compostos formados.

- Quantificar todos os voláteis identificados. 


\section{REVISÃO DA LITERATURA}

Desde a antiguidade, as plantas têm sido utilizadas como medicamentos, na prevenção, no tratamento e na cura de distúrbios, disfunções ou doenças em homens e animais. Os povos primitivos iniciaram a identificação de vegetais que melhor se adequavam ao uso medicinal, da época de colheita, das técnicas de extração e de modos de conservação (Bugno et al., 2005).

A revolução industrial e as descobertas de substâncias ativas em plantas medicinais provocaram a substituição dos medicamentos vegetais por produtos contendo princípios ativos deles extraídos, ou seus derivados sintéticos, por meio de modificações estruturais e síntese de novas moléculas. Os produtos naturais passaram a apresentar um significado místico e esta abordagem era oposta ao novo modo de vida das sociedades industrializadas, que consideravam a utilização de produtos naturais como uma opção de pessoas incultas e de baixa renda e não afetaria a estes produtos qualquer valor farmacológico (Rates, 2001).

Porém, com o passar do tempo, as plantas continuaram sendo importantes no desenvolvimento de novas drogas e ainda hoje, cerca de $30 \%$ dos fármacos prescritos são derivados de plantas e dos 252 fármacos considerados básicos ou essenciais pela Organização Mundial da Saúde (OMS), 11\% são exclusivamente de origem vegetal (Calixto, 2005).

Nos últimos anos, devido à ampla divulgação pela imprensa em geral da relação entre alimentação e saúde, a preocupação da sociedade ocidental com os alimentos tem aumentado de forma exponencial (Anjo, 2004) e, portanto, nas últimas décadas, tem-se verificado uma tendência mundial de aumento na demanda por plantas e preparações de origem vegetal como recurso terapêutico, influenciado por fatores econômicos, sociais e culturais (Abu-Irmaileh e Afifi, 2003; Bent e Ko, 2004). 
Alimentos funcionais são definidos como qualquer substância ou componente de um alimento que proporciona benefícios para a saúde, inclusive a prevenção e o tratamento de doenças. Esses produtos podem variar de nutrientes isolados, produtos de biotecnologia, suplementos dietéticos, alimentos geneticamente construídos até alimentos processados e derivados de plantas (Pollonio, 2000).

Para Borges (2001), eles devem exercer um efeito metabólico ou fisiológico que contribua para a saúde física e para a redução do risco de desenvolvimento de doenças crônicas. Nesse sentido, devem fazer parte da alimentação usual e proporcionar efeitos positivos, obtidos com quantidades não tóxicas e que não se destinem a tratar ou curar doenças, estando seu papel ligado à redução do risco de contraí-las.

Fitoquímicos são substâncias produzidas naturalmente pelas plantas, para protegê-las contra vírus, bactérias e fungos. Elas parecem ajudar na preservação de alguns tipos de doenças e incluem centenas de substâncias como carotenóides, flavonóides, isoflavonas, compostos fenólicos, licopeno, saponinas, terpenos, sulfetos alílicos, indol entre outras (Simões et al., 2003).

Os fitoquímicos podem ser facilmente encontrados nos alimentos que fazem parte da nossa alimentação habitual: frutas, vegetais, grãos e sementes. Por meio de plantas medicinais secas ou frescas e seus extratos naturais, a fitoterapia trata várias doenças. Plantas medicinais são aquelas que têm aplicação consagrada pelo uso médico ou pelo povo (Panizza, 1997).

A importância do emprego da matéria-prima vegetal, na obtenção de um fitoterápico, representa um fator importante na produção de um produto com qualidade. As matérias-primas ativas de origem vegetal (planta fresca, seca, inteira ou em partes), devido à sua complexidade de composição, requerem cuidados especiais, tanto no armazenamento quanto durante a sua transformação. Na produção de produtos fitoterápicos, grande atenção deve ser dada ao planejamento da preservação da qualidade físico-química e microbiológica, quer na matéria-prima, quer dos produtos intermediários e finais (Sonaglio et al., 2003).

No Brasil, a Resolução de Diretoria Colegiada (RDC) $n^{\circ} 267$ ressalta que as espécies vegetais utilizadas como alimentos não podem ser consideradas como 
medicamento ou serem utilizadas com finalidades medicamentosas e/ou terapêuticas (Brasil, 2005). Entretanto, Lorenzi e Matos (2002) classificaram 23 das 47 espécies citadas pela RDC como plantas medicinais pelo fato de serem utilizadas na medicina popular e também pelo fato das indústrias farmacêuticas utilizarem os fitoquímicos presentes nesses vegetais para a síntese de fármacos.

\subsection{Chá}

O chá é uma das bebidas mais populares. As infusões derivadas da planta Camellia sinensis L. Kuntze são a segunda bebida mais consumida em todo o mundo, perdendo apenas para a água (Owuor et al., 2008). Camellia sinensis pode ser um arbusto ou árvore de até 16 metros de altura (Ferrara et al., 2001) e pode ser cultivado em diversas regiões que possuem altas umidades, temperaturas amenas e solos ácidos desde o nível do mar até altas montanhas (FIG. 1) (Balentine et al., 1997).

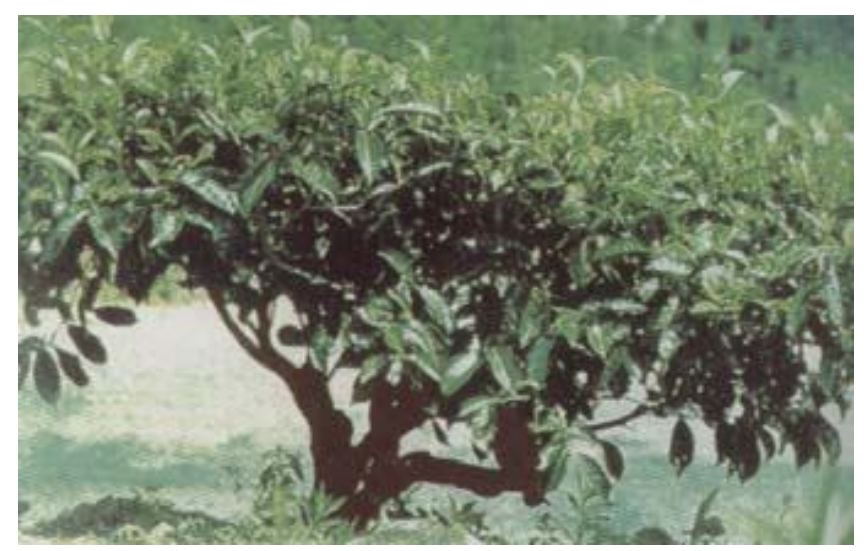

FIGURA 1 - Aspectos gerais da árvore C. sinensis.

A produção anual de folhas secas para o preparo de chá é estimada em 1,8 milhões de toneladas; isso equivale cerca de 40 litros de chá para cada habitante no mundo (Cheng et al., 2008). Embora seja uma planta muito utilizada atualmente, a Farmacopéia Brasileira (2000), Farmacopéia Britânica (2000) e a Farmacopéia Européia (2001) não contêm monografia sobre esta planta.

Segundo uma lenda chinesa, o chá foi descoberto acidentalmente por um imperador há 4.000 anos, enquanto de acordo com outras fontes, os chineses têm bebido 
chá desde 3.000 A.C. e mais de 4 milhões de acres são utilizados para seu cultivo. Essa bebida é consumida em todos os países do mundo e em alguns deles têm status cerimonial (Ferrara et al., 2001). Porém, pesquisas arqueológicas reportadas por Jelinek em 1978 sugerem que a infusão de folhas de diferentes plantas selvagens e de árvores de chá é praticada a mais de 500.000 anos (Dufresne e Farnworth, 2001).

As folhas de chá são usadas tanto socialmente, quanto para o uso medicinal. A medicina tradicional chinesa recomenda, desde 3.000 A.C., o chá verde para dores de cabeça, dores corporais, digestão, melhoria do sistema imune, desintoxicação, energético e prolongar a vida (Ferrara et al., 2001).

Segundo Weisburguer (1997), a história do chá como uma bebida data do ano de 2.700 A.C. na China. No Japão o consumo de chá foi introduzido por volta do século VI. Por um longo período, o chá só era consumido pelas camadas mais altas da sociedade, tornando-se popular somente 700 anos depois. O consumo então se difundiu por toda a Ásia e das colônias para as metrópoles (por exemplo, da Indonésia para a Holanda, da Índia para o Reino Unido), onde em meados do século XVII os ingleses divulgaram e popularizaram o chá por todo o mundo.

A denominação "chá" no mundo refere-se a infusões obtidas da planta $C$. sinensis, sendo que para outros tipos de planta usa-se apenas a denominação "infusão" (Penna et al., 2005). Entretanto, o Regulamento Técnico de Espécies Vegetais para o Preparo de Chás considera como chá 47 espécies vegetais (Brasil, 2005).

Os benefícios associados ao consumo de chá têm sido atribuídos a altas concentrações de antioxidantes, como os flavonóides e sua capacidade de captar radicais livres. Chá é geralmente consumido na forma de chá verde, chá preto, chá oolong e chá branco (Rusak et al., 2008).

Estudos epidemiológicos associam o consumo de $C$. sinensis com baixo risco de desenvolvimento de diversos tipos de câncer (Sato e Myata, 2000; Toit et al., 2001). Seus polifenóis têm demonstrado ter efetivo agente quimiopreventivo (Cabrera et al., 2003; Gosslau e Chen, 2004). Outras propriedades/benefícios são o aumento da atividade insulínica (Anderson e Polansky, 2002), capacidades antimicrobial, imunoestimulatória e antiinflamatórias (Saito et al., 2006), possui efeitos de proteção contra doenças 
cardiovasculares (Sano, et al., 2004) e cerebrais (Suzuki et al., 2004), inibição do crescimento de cáries (Sakanaka et al., 1989), inibição de alergias (Yeo et al., 1995), redução da pressão arterial sistêmica (An, 1998) e prevenção de gota (An et al., 1996).

Outros estudos demonstraram que a inclusão de 10 xícaras ou mais de chá verde por dia melhoram testes sanguíneos, indicando proteção contra danos no fígado. Todos os tipos de $C$. sinensis têm propriedades estimulantes, portanto gestantes ou pessoas que sofrem de ansiedade, insônia ou batimentos cardíacos irregulares devem limitar o consumo diário de 1 ou 2 xícaras, sendo que a última deve ser consumida pelo menos 3 horas antes de dormir (Ferrara et al., 2001).

Os efeitos de inibição da oxidação lipídica por meio de seus polifenóis são maiores do que os antioxidantes sintéticos, como o BHT (sigla em inglês para "butylated hydroxytoluene'), BHA (sigla em inglês para "butylated hydroxyanisole"), TBHQ (sigla em inglês para "tertiary butyl hydroquinone") e antioxidantes naturais como a vitamina E (Wanasundara e Shahidi, 1998).

Estudos também apontam que a EGCG, um tipo de catequina encontrado nesse tipo de chá, pode ter efeitos anti-HIV quando associado na periferia de receptores CD4 (Kawai et al, 2003), estimula a termogêneses, promovendo assim a perda de peso e influenciando na composição corporal (Dulloo et al., 1999).

\subsubsection{Chá verde}

O chá verde é mais consumido no Japão, China e Coréia e para sua obtenção as folhas extraídas são secas no ar, depois são fumegadas (vapor), enroladas e voltam a serem secas (Santana-Rios et al., 2001a). Sua cor é verde devido à inativação da polifenol oxidase por meio do tratamento das folhas frescas por calor (Koo e Noh, 2007).

O chá verde foi introduzido no Japão pela China e rapidamente se tornou uma das bebidas mais populares. Hoje, o seu "flavor" é utilizado na fabricação, desde sorvetes até vários tipos de bebidas industrializadas (Yamaguchi e Shibamoto, 1981). 


\subsubsection{Chá preto}

O chá preto representa $90 \%$ do consumo total mundial, sendo a Índia a maior produtora e exportadora desse tipo de chá (Bhattacharyya et al., 2007). Seu processamento segue algumas etapas utilizadas para chá verde, mas com a diferença de que em umas das etapas, as folhas são esmagadas ou quebradas, sofrendo oxidação, antes de serem secas (Santana-Rios et al., 2001a).

Nesse processamento, as catequinas presentes nas folhas sofrem oxidação, o que é muito importante para o desenvolvimento de cor e sabor da bebida. A oxidação é enzimática por ação da polifenoloxidase presente nos vacúolos das células. Para a enzima ser liberada destes vacúolos, as folhas precisam ser trituradas e deixadas expostas ao oxigênio do ar. Anteriormente, acreditava-se que o processo era fermentativo e, por este motivo, é ainda conhecido como "fermentação" para a produção do chá preto (Matsubara e Rodriguez-Amaya, 2006a,b). O tempo de fermentação é fundamental para a qualidade final do chá. É nesse processo que as folhas mudam da cor verde para a cor preta ou marrom e o aroma de gramínea é transformado em floral (Bhattacharyya et al., 2007).

\subsubsection{Chá oolong}

O chá oolong é mais consumido no Japão e China e sua obtenção é da mesma forma que o chá preto, a diferença entre eles é que o oolong sofre oxidação parcial (An et al., 1996).

\subsubsection{Chá branco}

O chá branco é obtido por meio de folhas recém formadas e brotos da planta e não sofre nenhum processamento além da secagem pelo sol. Poucos trabalhos foram realizados com o chá branco, mas estudos têm mostrado que esse tipo de chá pode ter mais atividade antimutagênica que o chá verde, devido a maiores concentrações de alguns antioxidantes (Santana-Rios et al., 2001a,b).

Na FIG. 2 são mostrados os diferentes processos, resultando em diferentes tipos de chá, que a planta $C$. sinensis pode sofrer. 


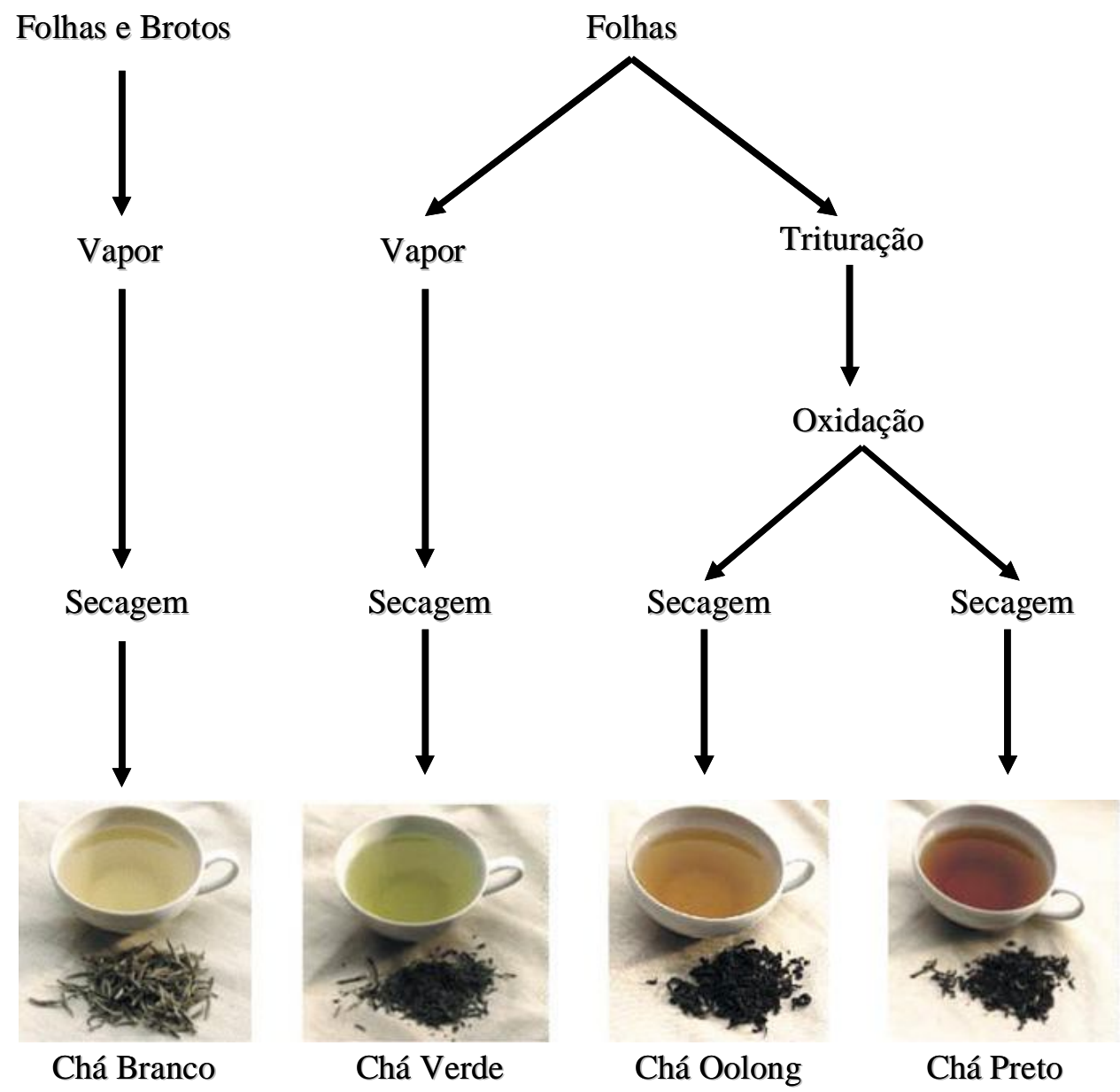

FIGURA 2 - Esquema de obtenção dos diferentes tipos de chá da planta C. sinensis.

\subsection{Sistema olfatório}

Nos humanos, a sensação de "flavor" é devido aos três principais sistemas quimiorreceptores: gustação, que é a capacidade de sentir o sabor por meio de receptores na língua; olfato, que é a capacidade de sentir cheiros por meio do nariz e o nervo trigêmeo, que é responsável pela irritação. O sabor é utilizado para detectar compostos não-voláteis enquanto o cheiro é responsável por detectar compostos voláteis. Receptores do trigêmeo estão localizados nas membranas mucosas e na pele e respondem a muitos compostos voláteis sendo especialmente importantes para detectar substâncias irritantes encontrados, como por exemplo, nas pimentas. Para perceber o "flavor", todas as três formas de percepção são utilizadas, entretanto o sistema olfatório é o que contribui mais (Dutta et al., 2003a). 
A sensação de cheiro é um processo químico e neural onde as moléculas odorantes estimulam as células do receptor olfativo que estão localizadas no alto do nariz. Os cheiros são divididos em dois tipos, simples e complexos, onde a natureza do estímulo e não a qualidade de sensação é que distingui esses grupos. Um odor simples é aquele que consiste de um tipo de molécula odorífica, enquanto um odor complexo é a mistura de muitos e diferentes tipos de moléculas odoríficas. Todos os cheiros que ocorrem naturalmente são misturas complexas. Odorantes são tipicamente pequenas moléculas orgânicas hidrofóbicas contendo um ou dois grupos funcionais. O tamanho, forma e as propriedades das moléculas polares determinam suas propriedades odoríficas (Dutta et al., 2003b).

Grandes padrões de resposta são mostrados pelo sistema olfatório dos mamíferos, que é composto de um grande número de receptores inespecíficos, com cerca de 300 receptores olfativos diferentes já identificados, em um total de aproximadamente de 50 milhões. Estas células enviam os seus sinais para nodos secundários e, em seguida, para células localizadas no bulbo olfatório. Existe nesta fase uma convergência entre 1.000 e 20.000 células receptoras primárias, que é ligada com células secundárias, seguido por uma divergência limitada (Pearce et al., 1993).

Isto sugere que as células secundárias estão envolvidas na integração das informações. A natureza das células primárias não é especificidade enquanto as células secundárias respondem a distintas categorias de odores. As células secundárias interagem uma com as outras e também com células maiores formando um sistema complexo nãolinear com excitação e inibição locais, ambas ajudando a produzir um alto grau de sensibilidade (ppb ou mais) e especificidade (Dutta et al., 2003b).

\subsection{Compostos Orgânicos Voláteis}

A aceitabilidade de um produto pelo consumidor é diretamente proporcional à quantidade de "flavor". Compostos não-voláteis são geralmente responsáveis pelo sabor enquanto os compostos voláteis dão o aroma. Em chás, compostos orgânicos voláteis (COV) estão presentes em pequenas quantidades, chegando a representar $0,01 \%$ total do peso seco da erva, porém possui alto impacto no "flavor" do produto final (Rawat et al., 
2007). Já foram identificados mais de 500 tipos de compostos voláteis que podem compor um "flavor" (Rawat e Gulat, 2008).

Entre os principais componentes químicos presentes no chá que influenciam o “flavor" estão os polifenóis, cafeína, açúcares, ácidos orgânicos, compostos voláteis e aminoácidos. Os compostos fenólicos, como as teaflavinas, são muito importantes, pois determinam a qualidade do chá, sendo responsáveis pela cor e "flavor". Os compostos voláteis podem variar de composição química devido à geografia, época de plantio e colheita e também dos processos de beneficiamento (Gulati et al., 1999). Borse et al. (2002) trabalhando com chá preto de nove regiões da Índia relataram que cada amostra apresentou características na composição orgânica volátil próprias e não houve duas amostras que tivessem combinado. Essa característica pode ser utilizada para rastrear a origem dos chás.

No caso de infusões, como as de $C$. sinensis, o sabor determina a qualidade do produto e seu preço de mercado, evidenciando a importância do conhecimento das rotas bioquímicas de geração dos compostos voláteis, que são em grande parte responsáveis pelo aroma, durante o processamento (Machado et al., 2007).

Os COV de chás são classificados em dois grupos, onde no Grupo 1, as lipases presentes nas folhas liberam ácidos graxos insaturados das membranas celulares que, por sua vez, sofrem outras reações de degradação originando compostos voláteis indesejáveis para este produto, como trans-2-hexenal. No Grupo 2, a degradação de carotenóides leva à formação de compostos responsáveis pelo aroma doce e agradável. A conversão de $\beta$ caroteno em $\beta$-ionona e outros compostos com ionona substituinte e/ou seus produtos de oxidação, bem como a conversão de outros carotenóides em linalol, aldeídos terpênicos e cetonas já foram relatadas e são dependentes da concentração e do tipo de carotenóide presente nas folhas, bem como da presença de antioxidantes, notadamente os polifenóis. Os aminoácidos originam aldeídos que podem ser oxidados a ácidos carboxílicos ou reduzidos a álcoois. A fenilalanina sofre desaminação para originar o fenilacetaldeído, composto com aroma floral (Ravichandran, 2002; Ravichandran e Parthiban, 1998; 2000). 


\subsection{Cuidados na produção}

A maior industrialização e comercialização de fitoterápicos tornaram seu uso um problema de Saúde Pública. O aumento da demanda, associado à falta de fiscalização efetiva que garanta desde a exploração racional dos recursos naturais empregados como matéria-prima, até a liberação do produto acabado, contribuem para a disponibilidade e acesso a produtos muitas vezes sem condições adequadas ao uso, sem garantia da qualidade, segurança e eficiência, fundamentais para a recuperação ou preservação da saúde do consumidor (De Smet, 2004; Giveon et al., 2004).

Fatores como poluição na água de irrigação, atmosfera, solo, condições da coleta, manipulação, secagem e estocagem são importantes a serem considerados no controle de produtos naturais, por permitirem altos níveis de contaminação microbiana, por vezes patogênica (Mandeel, 2005). A presença de fungos potencialmente toxigênicos podem ser encontrados nesses produtos, indicando um grande potencial para a presença de micotoxinas que podem causar efeitos agudos e crônicos nos diferentes órgãos e sistemas do corpo humano (Aquino et al., 2007).

Existem mais de 300 toxinas conhecidas, entretanto, somente algumas têm sido bem estudadas. Para as micotoxinas humanas, fusariotoxinas são consideradas de grande importância devido a sua periculosidade e as aflatoxinas e ocratoxinas são apontadas como carcinogênicas (Nunes, 2003).

Em alguns tipos de fitoterápicos, a porcentagem de contaminação em amostras embaladas foram maiores daquelas não embaladas e isso se deve, entre outros fatores, a umidade dentro da embalagem e métodos inadequados de manipulação e estocagem (Abou-Arab et al., 1999).

Efuntoye (1999) avaliou a relação entre tempo de estocagem das plantas, por um período de até três meses e níveis toxigênicos, demonstrando que, quanto maior o tempo de armazenamento, maior era a produção de toxinas. Após 90 dias, os níveis toxigênicos apresentaram elevação máxima.

Bugno et al., (2005) avaliaram 91 amostras de plantas com propriedades fitoterápicas, compostas por 65 espécies vegetais distintas e considerando as especificações farmacopéicas para a enumeração de populações microbianas presentes e para pesquisa de 
microrganismos específicos, verificou-se que 92,3\% das drogas vegetais analisadas estavam em desacordo com um ou mais parâmetros microbiológicos.

Em seu trabalho, Nunes (2003) demonstrou altos níveis de aflatoxinas em 50 amostras de cinco tipos de fitoterápicos de uso comum na cidade de São Paulo. Ele constatou que $80 \%$ das amostras analisadas apresentaram elevados índices de contaminação, tornando o produto impróprio para o consumo, sendo que $56 \%$ dos isolados de Aspergillus flavus e os dois isolados de Aspergillus parasiticus produziram aflatoxinas.

\subsection{Irradiação}

O início da história da irradiação de alimentos surgiu com a própria história da radiação. Com o descobrimento dos raios-X por Roentgen em 1895 e a identificação da radioatividade por Becquerel em 1896, um grande de pesquisas surgiram sobre os efeitos biológicos da radiação em organismos vivos. Rapidamente inventores descobriram aplicações práticas para a radiação. A principal vantagem na aplicação da radiação ionizante em alimentos observada era a total ausência do emprego de compostos químicos (Morrissey e Herring, 2002).

Com o desenvolvimento tecnológico durante a segunda guerra mundial, foram produzidos equipamentos que poderiam ser adaptados e aumentar a aplicação do processamento por radiação. Estudos realizados pelos Estados Unidos estimularam a realização de experimentos por outros países. Um dos primeiros usos comerciais da irradiação de alimentos na Europa ocorreu na Alemanha em 1957, quando produtores de condimentos começaram a melhorar qualidade higiênica de seus produtos (Diehl, 2002).

No Brasil, a irradiação de alimentos começou a se intensificar no final da década de 60. Em 1974, o Instituto de Pesquisas Energéticas e Nucleares instalou no Centro de Tecnologia das Radiações um acelerador de elétrons de 1,5MeV para aplicações industriais. E em 1975 criou-se um convênio com a Universidade de São Paulo, para implantação de cursos de pós-graduação no instituto (IPEN, 2004).

As décadas de 70 e 80 foram mundialmente dedicadas às pesquisas toxicológicas para comprovar a inocuidade dos alimentos irradiados, uma vez que esse era 
o aspecto mais questionado. Os projetos foram desenvolvidos em 24 países sob a coordenação de um Comitê formado pela International Atomic Energy Agency (IAEA/Viena), Food Agriculture Organization (FAO/Roma) e Organization for Economic Cooperation (OEC/Paris) e teve como órgão consultivo a Organização Mundial da Saúde (OMS). Após intensivos estudos, que envolveram, além de testes químicos, experimentos com animais alimentados com diversos produtos irradiados, o Comitê concluiu, em novembro de 1980, "que a exposição de qualquer produto alimentício a doses de até 10kGy não apresentava perigo toxicológico; portanto, testes toxicológicos com alimentos assim tratados não eram mais necessários" (WHO, 1999).

O termo radiação se refere aos processos físicos de emissão e propagação de energia (CNEN, 2009a), enquanto o termo irradiação é utilizado para a aplicação desta energia a um determinado material, atingindo objetivos pré-estabelecidos (CNEN, 2009b). A principal aplicação da radiação de alta energia é que ela causa ionização no meio que é absorvida, ou seja, é capaz de remover elétrons de suas órbitas em átomos ou moléculas. Por essa razão é denominada radiação ionizante (Molins, 2001).

$\mathrm{Na}$ interação da radiação eletromagnética com a matéria estão envolvidos vários mecanismos (Galante, 2003):

- A principal interação dos fótons ocorre por meio do Efeito Compton: espalhamento inelástico do fóton incidente, que perde parte de sua energia, com os elétrons atômicos. Os fótons são espelhados e o elétron secundário é ejetado do átomo. Tanto o fóton quanto o elétron secundário emergem em vários ângulos, cada um com energia menor do que a do fóton incidente. Este processo é predominante em fótons de energia entre 0,05 e $10 \mathrm{MeV}$ em um meio de número atômico baixo, como a água.

- Fótons de energia baixa, perto da energia de ligação do elétron orbital, sofrem Absorção Fotoelétrica: toda energia do fóton incidente é transferida para o elétron e resulta na emissão de fotoelétrons por causa da ejeção de elétrons orbitais. A energia cinética do fotoelétron ejetado é igual à diferença entre a energia do fóton incidente e a energia de ligação dos elétrons. Acompanhando a emissão do fotoelétron está à emissão de raios $\mathrm{X}$ característico, um efeito conhecido como fluorescência atômica. 
- Quando a energia do fóton é maior que a massa de repouso dos elétrons e pósitrons $(>1,02 \mathrm{MeV})$ pode ocorrer a Produção de Pares. Esta porção de energia do fóton é convertida em massa na forma de um elétron e um pósitron e a energia restante aparece como a energia cinética das duas partículas. A probabilidade da produção de pares aumenta com a energia do fóton incidente e com o quadrado do número atômico do material irradiado. Depois de diminuir a velocidade o pósitron recombina com um elétron, resultando na aniquilação das partículas, isto é, ocorre a emissão simultânea de dois fótons cada um com energia de $0,51 \mathrm{MeV}$.

A quantidade de radiação ionizante absorvida é chamada de dose de radiação absorvida e a unidade utilizada é o Gray (Gy) (onde 1Gy é igual a 100rads e 1rad equivale a $100 \mathrm{erg} / \mathrm{g}$ ), sendo que $1 \mathrm{~Gy}$ é igual à energia de 1 Joule absorvido por $1 \mathrm{~kg}$ de material (Olson, 1998).

De acordo com o Codex General Standard for Irradiated Foods (2003), para irradiação de alimentos só são permitidos os raios gama, provenientes de radionuclídeos de ${ }^{60} \mathrm{Co}$, com energia podendo chegar até $1,33 \mathrm{MeV}$ e ${ }^{137} \mathrm{Cs}$, com energia de $0,662 \mathrm{MeV}$; raios $\mathrm{X}$, com energia máxima de $5 \mathrm{MeV}$ e feixes de elétrons, que são gerados por máquinas que podem atingir energia máxima de até $10 \mathrm{MeV}$. Esses tipos de radiação são permitidos, porque além de produzirem os efeitos desejados nos alimentos, não induzem a radioatividade nestes ou em materiais que os acompanham, como por exemplo, as embalagens (Farkas, 2006).

Estas fontes de radiação não induzem radioatividade mensurável no alimento porque a energia limiar para a reação $(\gamma, n)$ está bem acima de $10 \mathrm{MeV}$ para todos os isótopos presentes no alimento (Findlay et al, 1993; ICGFI, 1995; Wakeford et al, 1991; Woods e Pikaev, 1994). O processamento de alimentos por radiação requer uma exposição controlada e cuidadosa frente à radiação ionizante de energia conhecida. A exposição deve ser adequada para produzir o resultado desejado (Farkas, 2001).

A escolha da fonte para a irradiação vai depender do material a ser irradiado e do objetivo a ser atingido. $\mathrm{O}$ uso da radiação proveniente de ${ }^{60} \mathrm{Co}$ possui grande penetrabilidade e são utilizadas na irradiação de produtos de grande espessura. Os aceleradores de elétrons possuem pequena penetração (apenas alguns milímetros) e são usados para a irradiação superficial de alimentos ou para produtos a granel, de fina 
espessura (Fanaro et al., 2007a;b). Irradiadores com fontes de ${ }^{60}$ Co são os mais utilizados, atualmente, para o processamento de alimentos (IAEA, 2001).

O tratamento com radiações ionizantes pode ser usado de forma independente ou combinado às técnicas já existentes, tais como secagem, fermentação, tratamento químico, tratamento pelo calor, conservação a baixas temperaturas ou em atmosferas modificadas (Rossi e Jesus, 1994). Uma grande vantagem do processo de irradiação é que ele permite a diminuição do uso de produtos químicos, usados como conservantes e antibióticos, em alimentos (IAEA, 2001).

A legislação brasileira aprova o uso da radiação ionizante por meio da $\mathrm{RDC} \mathrm{n}^{\circ}$ 21, desde que seu uso seja para a finalidade sanitária, fitossanitárias e/ou tecnológicas e a dose mínima absorvida seja suficiente para alcançar a finalidade pretendida e a dose máxima seja inferior a dose que comprometa as propriedades funcionais ou quaisquer atributos do alimento. Uma das principais observações, e que deve ser sempre ressaltada, é que o processo de radiação, bem como qualquer outro tratamento aplicado nos alimentos não deve substituir as boas práticas de fabricação e manuseio (Brasil, 2001).

A resolução ainda descreve que a embalagem deve ter condições higiênicas aceitáveis, ser apropriada para o procedimento de irradiação, estar de acordo com a legislação vigente e aprovada pela autoridade sanitária competente. Na rotulagem dos alimentos irradiados, além dos dizeres exigidos para os alimentos em geral e específico do alimento, deve constar no painel principal: "ALIMENTO TRATADO POR PROCESSO DE IRRADIAÇÃO", com as letras de tamanho não inferior a um terço (1/3) do da letra de maior tamanho nos dizeres de rotulagem. Quando um produto irradiado é utilizado como ingrediente em outro alimento, deve declarar essa circunstância na lista de ingredientes, entre parênteses, após o nome do mesmo.

Existe ainda, um símbolo internacional, a radura, utilizado para identificar os alimentos que sofreram tratamento por radiação ionizante (FIG. 3) 


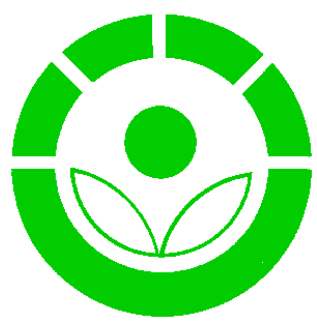

FIGURA 3 - Símbolo internacional para alimentos irradiados.

A radiação pode causar uma variedade de efeitos físicos e bioquímicos nos microrganismos. Uma vez absorvida por um material biológico, a radiação ionizante pode ter ação direta ou indireta sobre o material que recebeu este processamento (Hansen e Shaffer, 2001).

Quando a radiação age de forma direta no material biológico, ocorre a excitação ou ionização de moléculas de ácido nucléico e a partir daí serão conduzidas mudanças biológicas que podem levar a morte celular (Alcarde et al., 2003).

Considerando que a sensibilidade à radiação de macromoléculas é aproximadamente proporcional a sua massa molar, Pollard (1966) estimou que uma dose de 100 Gy danificaria $2,8 \%$ do DNA de uma célula bacteriana, enquanto que a mesma dose danificaria $0,14 \%$ das enzimas e apenas $0,005 \%$ dos aminoácidos.

O dano correspondente a $2,8 \%$ do DNA pode ser letal para uma ampla fração de organismos vivos, principalmente para organismos complexos. Os efeitos da quebra do DNA em alimentos são mostrados por diversos autores (Araújo et al., 2004; Fanaro et al., 2007a,b; Villavicencio et al., 2000). Em contraste, o dano de 0,14\% causado às moléculas das enzimas seria difícil de ser detectado, mesmo com métodos analíticos sofisticados e uma mudança de $0,005 \%$ nos aminoácidos em sistemas biológicos não pode ser detectada. Essas considerações explicam o porquê uma dada dose pode ter um efeito letal nos microrganismos em uma amostra de alimento irradiado sem causar muita alteração na composição química do alimento (Aquino, 2003).

O efeito indireto é ocasionado pela interação da radiação com a molécula de água (radiólise), gerando os chamados radicais livres. Estes irão interagir com outros 
constituintes do material biológico tratado com radiação, podendo trazer sérias conseqüências para o mesmo (Tritsch, 2000).

Os produtos da radiólise da água são (WHO, 1994):

$\mathrm{OH} \cdot$ - Radical hidroxila

$\mathrm{e}_{\mathrm{aq}}^{-}-$Elétron aquoso ou hidratado

$\mathrm{H} \cdot$ - Átomo de hidrogênio

$\mathrm{H}_{2}$ - Hidrogênio

$\mathrm{H}_{2} \mathrm{O}_{2}$ - Peróxido de hidrogênio

$\mathrm{H}^{+}$aq - Próton hidratado

Enquanto $\mathrm{OH}^{\cdot}$, e ${ }_{\text {aq }}^{-}$e $\mathrm{H}^{\cdot}$ são espécies reativas transitórias, $\mathrm{H}_{2}$ e $\mathrm{H}_{2} \mathrm{O}_{2}$ são os únicos produtos da radiólise da água estáveis. Por causa das reações que sofrem, eles são largamente consumidos. Essas reações estão demonstradas a seguir:

$$
\begin{aligned}
& \mathrm{H}_{2} \mathrm{O}_{2}+\mathrm{e}_{\text {aq }}^{-} \rightarrow \mathrm{OH}^{\cdot}+\mathrm{OH}^{-} \\
& \mathrm{H}_{2}+\mathrm{OH}^{\cdot} \rightarrow \mathrm{H}_{2} \mathrm{O}+\mathrm{H}^{\cdot}
\end{aligned}
$$

Eles são conseqüentemente produzidos em baixas quantidades, mesmo quando as doses de radiação são altas. A saturação da água com o oxigênio pode aumentar intensamente a produção de $\mathrm{H}_{2} \mathrm{O}_{2}$. A formação de peróxido de hidrogênio, conhecido por ser um agente oxidante, tem grande significado na irradiação de alimentos. $O$ radical hidroxila é um poderoso agente oxidante e o elétron aquoso é um forte agente redutor, enquanto o átomo de hidrogênio é um agente redutor menos efetivo (Diehl, 1995).

Sabe-se que boa parte dos danos causados a uma célula pela radiação ionizante ocorre pela ação indireta da radiação. Isto se deve ao fato de que a maioria das células vivas apresenta em média $80 \%$ de água em sua composição. Mesmo produtos aparentemente secos contêm água, como farinha de trigo (13\%), vegetais desidratados (10\%), nozes (5\%) entre outros (WHO, 1994). 
A dosimetria é uma ferramenta importante e obrigatória quando se usa irradiação de alimentos (Brasil, 2001), pois ela trata da determinação da dose absorvida ou a taxa de dose resultante da interação da radiação ionizante com a matéria. A determinação da dose exata e reprodutível em um processo industrial permite uma verificação da eficiência do mesmo e pode ser usada para o controle de qualidade ou para a otimização da rotina de instalações comerciais (Galante, 2003).

A América (Estados Unidos, Canadá e Brasil) é o segundo continente que mais irradia alimentos no mundo (166.400 toneladas), perdendo apenas para o continente asiático (183.309 toneladas), entretanto é o que mais utiliza a radiação ionizante em especiarias, frutas, grãos e hortaliças. O Brasil é o quarto maior irradiador de alimentos (23.000 toneladas), atrás da China (146.000 toneladas), Estados Unidos (92.000 toneladas) e Ucrânia (70.000 toneladas). A estimativa é que 404.804 toneladas de alimentos são irradiados no mundo (Kumea et al., 2009).

\subsection{Efeitos da radiação nos alimentos}

O efeito da radiação gama sobre a qualidade higiênica e o processo de extração de inúmeros componentes de diversos tipos de plantas medicinais tem sido estudado e relataram que irradiação é um método eficaz para a descontaminação microbiológica e o conteúdo essencial das substâncias ativas e da atividade farmacológica das ervas medicinais não alteram significativamente com irradiação (Yu et al., 2004).

Entretanto, análises cromatográficas de alguns extratos dessas plantas indicaram que mudanças na produtividade total e constituintes dos óleos voláteis após irradiação variou de zero a ligeira, dependendo da dose irradiação e na variedade de ervas. Portanto, a dose a ser aplicada para o controle microbiológico deve ser limitada por alterações indesejáveis nos componentes dos óleos voláteis, na qualidade e características sensoriais (Seo et al., 2007).

Lianzhong et al. (1998) trabalhando com pimenta em pó, demonstraram que a radiação ionizante com dose de 9,94kGy é mais eficiente no controle microbiológico e com uma menor perda de compostos que compõe o "flavor" do que quando submetido ao tratamento térmico de $120^{\circ} \mathrm{C}$ por $30 \mathrm{~min}$. 
Yu e Jo (2000) trabalhando com Angelica gigas Nakai (conhecido na Coréia como Dang Gui e utilizado no tratamento de doenças ginecológicas) irradiada com dose de 10kGy verificou por meio de cromatografia líquida de alta eficiência (CLAE) que não houve diferença entre as amostras irradiadas e não irradiadas.

Para reduzir a contaminação fúngica em plantas medicinais, uma dose média de $5 \mathrm{kGy}$ foi suficiente para reduzir a contagem para níveis aceitáveis, como observado em um estudo realizado por Aziz et al. (1997). Soriani et al. (2005) relataram que a radiação gama pode ser considerada eficaz para melhorar a qualidade microbiológica de ginkgo e guaraná irradiados com doses de até $17,8 \mathrm{kGy}$ e o conteúdo dos principais princípios ativos não foi modificada.

An et al. (2004) relatam que a atividade biológica e anti-microbiana de polifenóis isolados de folhas de chá verde irradiadas não mudaram quando submetidas a 40kGy. Thomas et al. (2008) irradiando chá preto, relatam que a dose de $7 \mathrm{kGy}$ pode ser efetiva no controle microbiológico e aumenta a vida útil do produto, sem a perda da qualidade dos constituintes presentes na bebida.

Gyawali et al. (2006) relataram que doses até 10kGy aumentam os compostos orgânicos voláteis em cebola, mas observando que quando aplicado à dose de 20kGy e os COV diminuíam 5,12\% em comparação com 10kGy. Koseki et al. (2002) relataram que ervas fitoterápicas tiveram a mesma ação terapêutica das plantas não irradiadas depois de expostas a doses de 10, 20 e $30 \mathrm{kGy}$.

Kim et al., (2000) demonstraram que radiação gama com doses até 10kGy é um método efetivo de aumentar a obtenção de diversos extratos assim como reduz a contaminação microbiologia de plantas medicinais da Coréia.

Aquino et al. (2007) relaram que a dose de $10 \mathrm{kGy}$ foi efetiva na descontaminação de fungos em folhas de plantas medicinais embaladas (incluindo o chá verde) e que essa condição foi mantida após trinta dias do tratamento com a radiação. Esse processamento aumenta a qualidade microbiológica e a segurança das plantas medicinais, assim como no controle de fungos toxigênicos como Aspergillus, Penicillium e Fusarium ssp. e que a irradiação pode ser um método efetivo na prevenção de deterioração por fungos nas plantas medicinais durante sua estocagem 
Em seu trabalho, Jo et al. (2003) relatam que os extratos de folhas de $C$. sinensis tiveram sua cor alterada com a dose de $20 \mathrm{kGy}$, porém a atividade antioxidante, por meio do radical DPPH (1,1-difenil-2-picrilhidrazil), manteve-se a mesma.

\subsection{Cromatografia gasosa}

A cromatografia é um método físico-químico de separação dos componentes de uma mistura, realizada por meio da distribuição desses componentes em duas fases, que estão em contato íntimo. Uma das fases permanece estacionária, enquanto a outra se move por meio dela. Durante a passagem da fase móvel sobre a fase estacionária, os componentes da mistura são distribuídos pelas duas fases de tal forma que cada um deles é seletivamente retido pela fase estacionária, o que resulta em migrações diferenciais desses componentes (Collins, 2006).

Técnicas relatadas para cromatografia têm sido usadas por séculos para separar materiais das plantas. Entretanto, foi um botânico e químico russo Michael Semenovich Tsvett que em 1906 usou pela primeira vez o termo "cromatografia" em dois trabalhos que descrevem suas experiências na separação dos componentes de extrato de folhas, nas quais usou colunas de vidro recheadas com vários sólidos, finalmente divididos e arrastou os diferentes compostos com éter de petróleo. O nome deriva do grego chrom (cor) e graphe (escrever), embora ele próprio explicitasse que o processo não dependia da cor, exceto para facilitar a identificação dos componentes separados (Braithwaite e Smith, 1996).

Apesar dessa experiência, considerou-se que a época moderna da cromatografia começou na década de 1930, quando Kuhn e Lederer "redescobriram" e aperfeiçoaram a técnica em coluna, repetindo as experiências de Tswett, separando e identificando as xantofilas da gema de ovo, usando uma coluna recheada com carbonato de cálcio pulverizado como fase estacionária e éter de petróleo como fase móvel (Collins, 2006).

Gases ou substâncias volatilizáveis podem ser separados utilizando-se cromatografia gasosa. A separação baseia-se na diferente distribuição das substâncias da amostra entre uma fase estacionária (sólida ou líquida) e uma fase móvel (gasosa) (David, 1974). 
A amostra, por meio de um sistema de injeção é introduzida em uma coluna contendo a fase estacionária. O uso de temperaturas convenientes possibilita a vaporização dessas substâncias que, de acordo com suas propriedades e as da fase estacionária, são retidas por tempos determinados e chegam à saída da coluna em tempos diferentes. $\mathrm{O}$ uso de um detector adequado na saída da coluna torna possível a detecção e quantificação dessas substâncias (Willet, 1993).

A cromatografia gasosa é uma técnica com um poder de resolução excelente, tornando possível a análise de dezenas de substâncias de uma mesma amostra. O uso bastante acentuado da cromatografia gasosa se deve também aos baixos limites de detecção que podem ser conseguidos. Dependendo do tipo de substância analisada e do detector empregado, consegue-se detectar cerca de $10^{-12} \mathrm{~g}$ ou até menos. Essa característica faz com que não haja necessariamente grandes quantidades da amostra, o que em certos casos, é um fator crítico e limita a utilização de outras técnicas (Collins, 2006).

Como desvantagem, essa técnica só pode ser utilizada na análise de substâncias voláteis e estáveis termicamente, caso contrário, há necessidade de se formar um derivado com essas características, o que nem sempre é viável (Grob, 2004).

A técnica de desenvolvimento usada em cromatografia gasosa é a eluição. Uma corrente de gás passa continuamente pela coluna e quando a amostra vaporizada é introduzida rapidamente nessa corrente de gás, ela é arrastada por meio da coluna. As substâncias presentes na amostra, depois de separadas, chegam ao detector, que gera um sinal para um sistema de registro e tratamento de dados (FIG. 4) (Collins, 2006). 


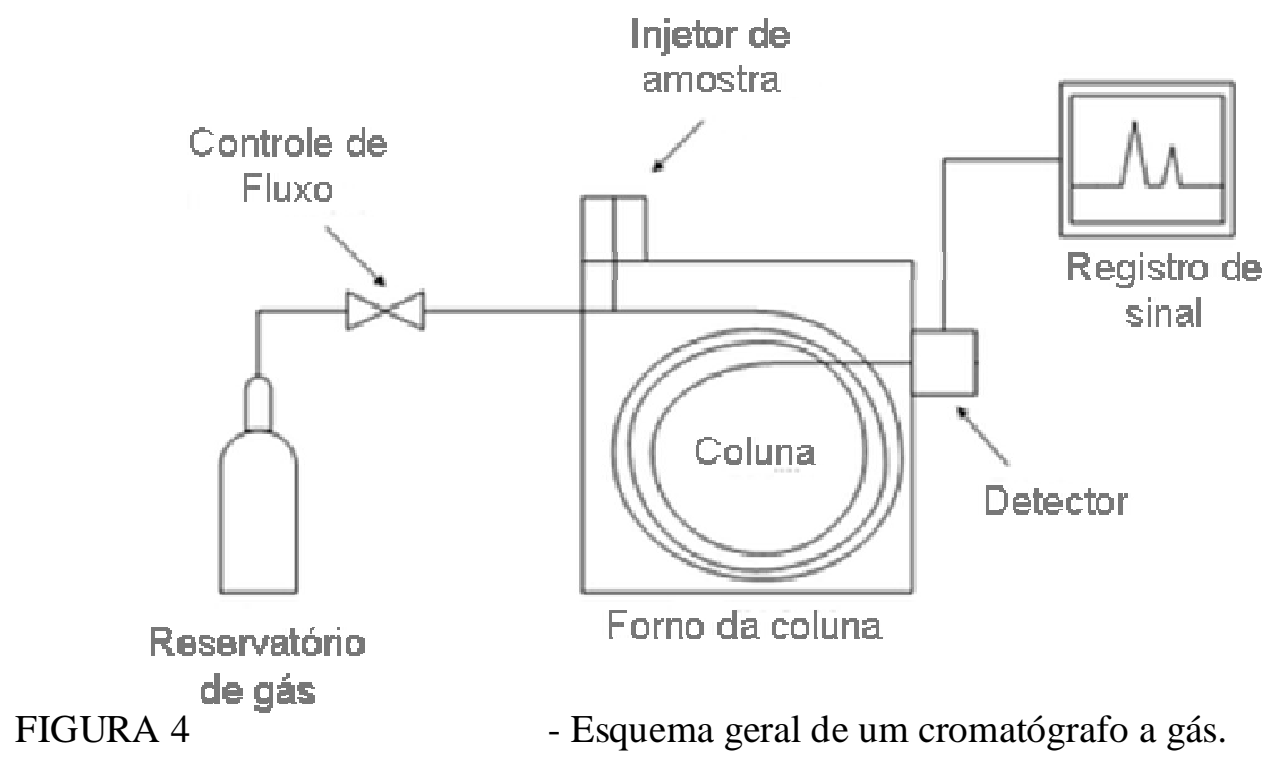

\subsection{Espectrometria de massa}

As indústrias de petróleo foram as primeiras a adotarem o uso da espectrometria de massas para análises quantitativas. Em 1943, nove componentes que estavam misturados foram identificados em 1 hora, comparado a procedimentos alternativos que duravam cerca de 240 horas (White, 1986).

Francis W. Aston construiu, em 1919 um "espectrógrafo de massa” capaz de separar íons com uma diferença de apenas $1 \%$ em suas massas e de registrá-los em uma placa fotográfica. Uma das primeiras descobertas feitas por Aston foi que o elemento neônio consistia em dois isótopos $\left({ }^{20} \mathrm{Ne} \mathrm{e}{ }^{22} \mathrm{Ne}\right)$. Após esta descoberta, ele descobriu 212 dos 281 isótopos que têm ocorrência natural (Davis e Frearson, 1987).

A espectrometria de massas é, atualmente, a melhor técnica de detecção para cromatografia, pois o espectrômetro é sensível a pequenas quantidades de analito, fornecendo informações qualitativas e quantitativas sobre compostos que são eluídos a partir de uma coluna e pode distinguir substâncias diferentes com o mesmo tempo de retenção. Pela da espectrometria de massas é possível determinar a seqüência de aminoácidos em proteínas e até seqüências de ácidos nucléicos do DNA (Gross, 2004).

A espectrometria de massa é uma técnica usada para o estudo das massas de átomos, moléculas ou fragmentos de moléculas. Para se obter um espectro de massas, as 
moléculas no estado gasoso ou espécies dessorvidas a partir de fases condensadas são ionizadas (normalmente em íons positivos). Os íons obtidos são acelerados por um campo elétrico, onde são separados de acordo com a sua razão entre sua massa e sua carga elétrica (m/z) e expelidos na direção do tubo analisador, onde sofrem a ação de um campo magnético perpendicular à direção de propagação. O tubo é mantido sob alto vácuo (aproximadamente $10^{-5} \mathrm{~Pa}$ ), de modo a evitar que os íons sejam defletidos por colisão com moléculas residuais do gás. O campo magnético deflete os íons na direção do detector, que se encontra na extremidade do tubo. Os íons mais pesados não sofrem deflexão expressiva, enquanto os íons mais leves são bastante defletidos (FIG. 5) (Constantin e Schnell, 1990).

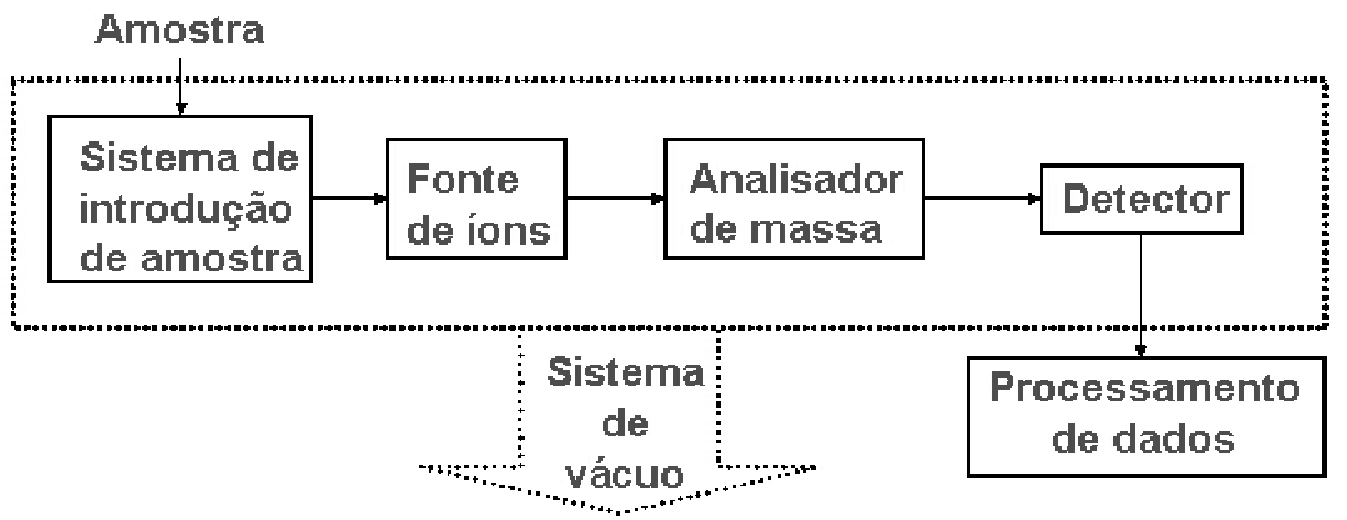

FIGURA 5 - Esquema geral de um espectrômetro de massas.

As moléculas que entram na fonte de íons são convertidas em íons pela ionização por elétrons. Os elétrons emitidos por um filamento aquecido (semelhante ao de uma lâmpada incandescente) são acelerados por meio de um potencial de $70 \mathrm{eV}$ antes de interagirem com as moléculas que entram na fonte de íons (FIG. 6) (Gross, 2004). 


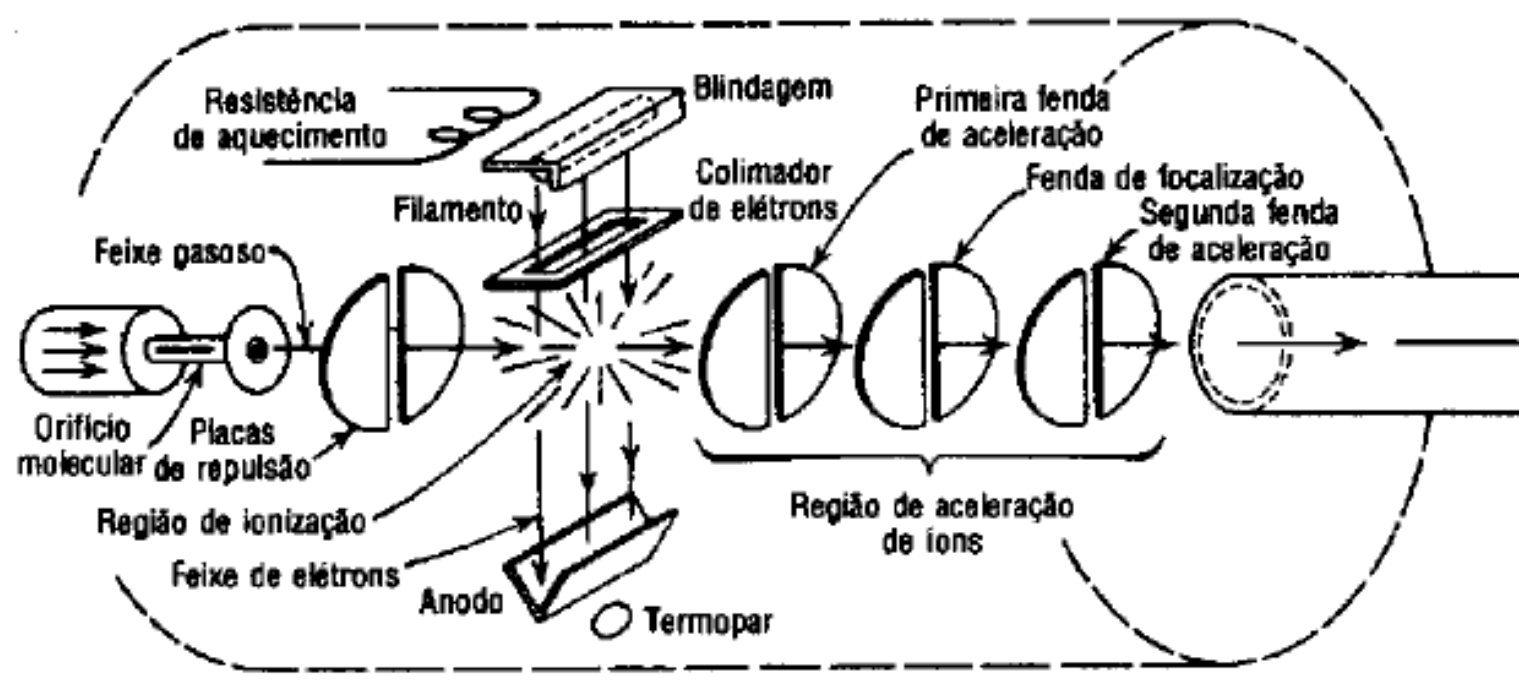

Figura 6 - Esquema da ionização por elétrons.

\subsection{Cromatografia gasosa acoplado ao espectrômetro de massa}

A cromatografia gasosa/espectrometria de massas - GC/MS (sigla inglês para Gás Chromatography/Mass Espectrometry) é a combinação de duas técnicas de análise: GC é uma técnica de separação e MS é uma técnica de identificação. A primeira permite separar os componentes de uma mistura complexa que então um espectro de massas pode ser obtido para análise de qualidade, enquanto o segundo quantifica essas substâncias (FIG. 7) (Masucci e Caldwell, 2004).

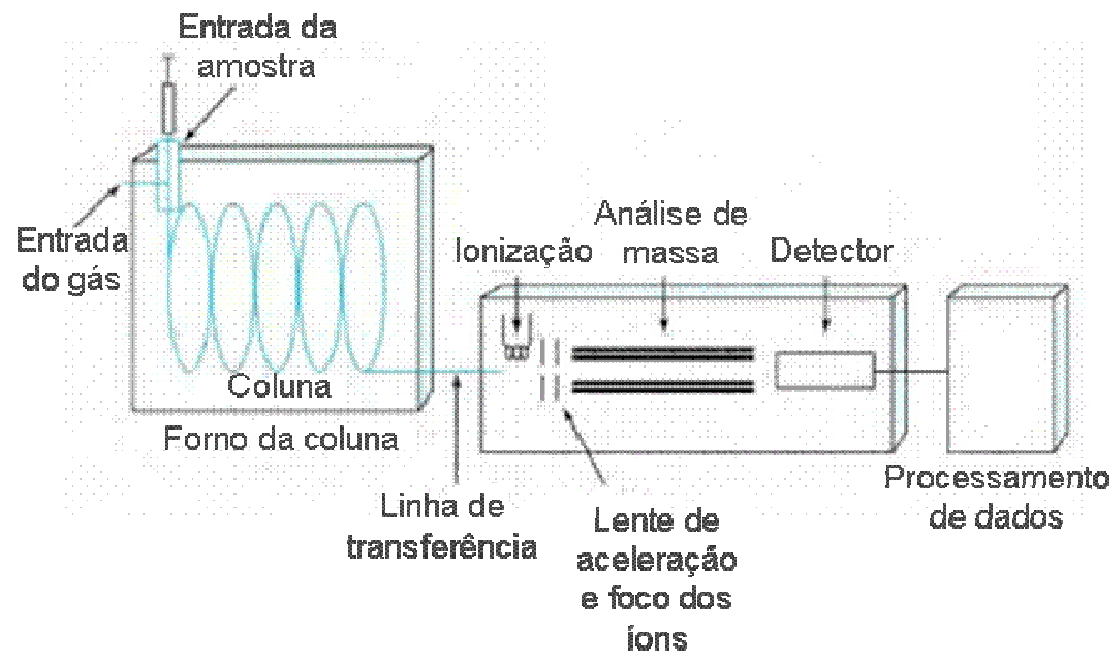

FIGURA 7 - Esquema de um cromatógrafo a gás acoplado a um espectrômetro de massa. 
A combinação dessas duas técnicas permitiu que diversas moléculas pudessem ser identificadas e assim diversos estudos puderam ser aprofundados. Yamaguchi e Shibamoto (1981) identificaram pela primeira vez o $\beta$-Ciclocitral e 2,6,6-Trimetilciclohexanona no chá verde. Esse último foi considerado pelos autores como um dos 10 compostos mais abundantes no chá verde.

Ning et al. (2008) separaram e identificaram os voláteis da planta Artemisia argyi, que é bastante utilizada como uma planta medicinal na China. Suwanagul e Richardson (1998) identificaram pela primeira vez 47 compostos em oito variedades de peras.

A combinação GC/MS supera deficiências ou limitações se fosse usado cada técnica separadamente. Por exemplo, utilizando somente o MS para analisar amostras impuras, pode ocorrer à sobreposição de dois ou mais espectros de massas. O uso do GC isoladamente pode deixar dúvidas sobre o resultado devido à ambigüidade que se pode obter identificando vários componentes apenas utilizando o tempo de retenção (Watson, 1997). 


\section{MATERIAIS E MÉTODOS}

\subsection{Amostras}

As amostras de chá verde e branco foram doadas pelo HERBARIUM LABORATÓRIO BOTÂNICO LTDA; as amostras de chá preto foram doadas pela MATE LEÃO JR.; e as amostras de chá oolong foram adquiridas no comércio varejista da cidade de São Paulo. As amostras foram sempre processadas em triplicata.

\subsection{Irradiação}

As amostras foram irradiadas no Centro de Tecnologia das Radiações IPEN/CNEN, em fonte de ${ }^{60} \mathrm{Co}$ utilizando-se a Gammacell 220 (A.E.C. Ltda) em temperatura ambiente nas doses de 0,5,10,15 e 20kGy. A taxa de dose foi de 2,41 kGy/h para o chá preto e 2,39 kGy/h para o chá verde, branco e oolong. O dosímetro Harwell Amber 3042 foi utilizado para medir a dose de radiação.

\subsection{Extração dos compostos voláteis}

Foi utilizada a técnica de hidrodestilação. Em um balão foram adicionados $700 \mathrm{ml}$ de água destilada e $100 \mathrm{~g}$ de cada tipo de chá. Como padrão interno, foi adicionado $10 \mu \mathrm{l}$ de timol diluído em etanol $(1 \mu \mathrm{g} / 1 \mu \mathrm{l})$. A extração se deu em $1 \mathrm{~h}$, à pressão ambiente, a $100^{\circ} \mathrm{C}$. A fase orgânica foi separada com $10 \mathrm{ml}$ de diclorometano por $1 \mathrm{~h}$, seca por fluxo de nitrogênio puro, re-suspendido com $1 \mathrm{ml}$ de diclorometano e armazenado no freezer $\left(-4^{\circ} \mathrm{C}\right)$ (adaptado de Machado et al., 2007; Ravichandran e Parthiban, 1998). 


\subsection{Separação dos compostos orgânicos voláteis (COV)}

A separação e identificação dos COV se deu em um cromatógrafo a gás HP 6980 acoplado a um espectômetro de massas HP 5973. A coluna utilizada foi a HP-5MS $(30 \mathrm{~m} / 0.25 \mathrm{~mm} / 0.25 \mu \mathrm{m})$ e o gás hélio foi utilizado como gás de arraste.

A temperatura do injetor foi de $200^{\circ} \mathrm{C}$ no modo "splitless". A rampa de temperatura do $\mathrm{GC}$ foi programada para temperatura inicial a $50^{\circ} \mathrm{C}$ por $30 \mathrm{~s}$, aumentando gradativamente a temperatura $\left(5^{\circ} \mathrm{C} / \mathrm{min}\right)$ até atingir $250^{\circ} \mathrm{C}$ e a temperatura final de $250^{\circ} \mathrm{C}$ por 30s. O volume de injeção das amostras foi de $1 \mu 1$ e o fluxo da coluna foi ajustado para $1 \mathrm{ml} / \mathrm{min}$. A temperatura na fonte foi de $230^{\circ} \mathrm{C}$ e na de $200^{\circ} \mathrm{C}$ na interface. A energia do MS foi de 70eV. O volume de injeção das amostras foi de $1 \mu 1$.

\subsection{Identificação dos compostos voláteis}

A identificação dos compostos voláteis foi efetuada pela da comparação dos seus espectros de massa com o banco de dados do sistema da biblioteca NIST 98. Os compostos não identificados, ou seja, possuíram o valor de match menor que 75 , não foram incluídos nesse trabalho.

\subsection{Quantificação dos compostos voláteis}

A quantificação dos compostos voláteis foi realizada por meio da relação do valor entre as médias das áreas obtidas de cada composto com a média da área do padrão interno.

\subsection{Análise estatística}

Para a análise estatística, utilizou-se a análise de componentes principais (ACP) com o nível de significância de 95\%, por meio do software Win-Das (Kemsley, 1998). 
A ACP é uma técnica que tem como objetivo principal da análise de componentes principais é a obtenção de um pequeno número de combinações lineares (componentes principais) de um conjunto de variáveis, que retenham o máximo possível da informação contida nas variáveis originais (Moita Neto e Moita, 1998). 


\section{REULTADOS E DISCUSSÃO}

De todas as amostras analisadas, o chá branco foi o chá com a menor quantidade de voláteis detectados, totalizando 103 compostos identificados após a irradiação (FIG. 8), entretanto foi o chá que mostrou sofrer menor influência da radiação ionizante, pois $37,86 \%(\mathrm{n}=39)$ do total dos compostos identificados foram estáveis a todas as doses de radiação e a irradiação formou 47,53\% (n=49) de novos compostos (FIG. 9).

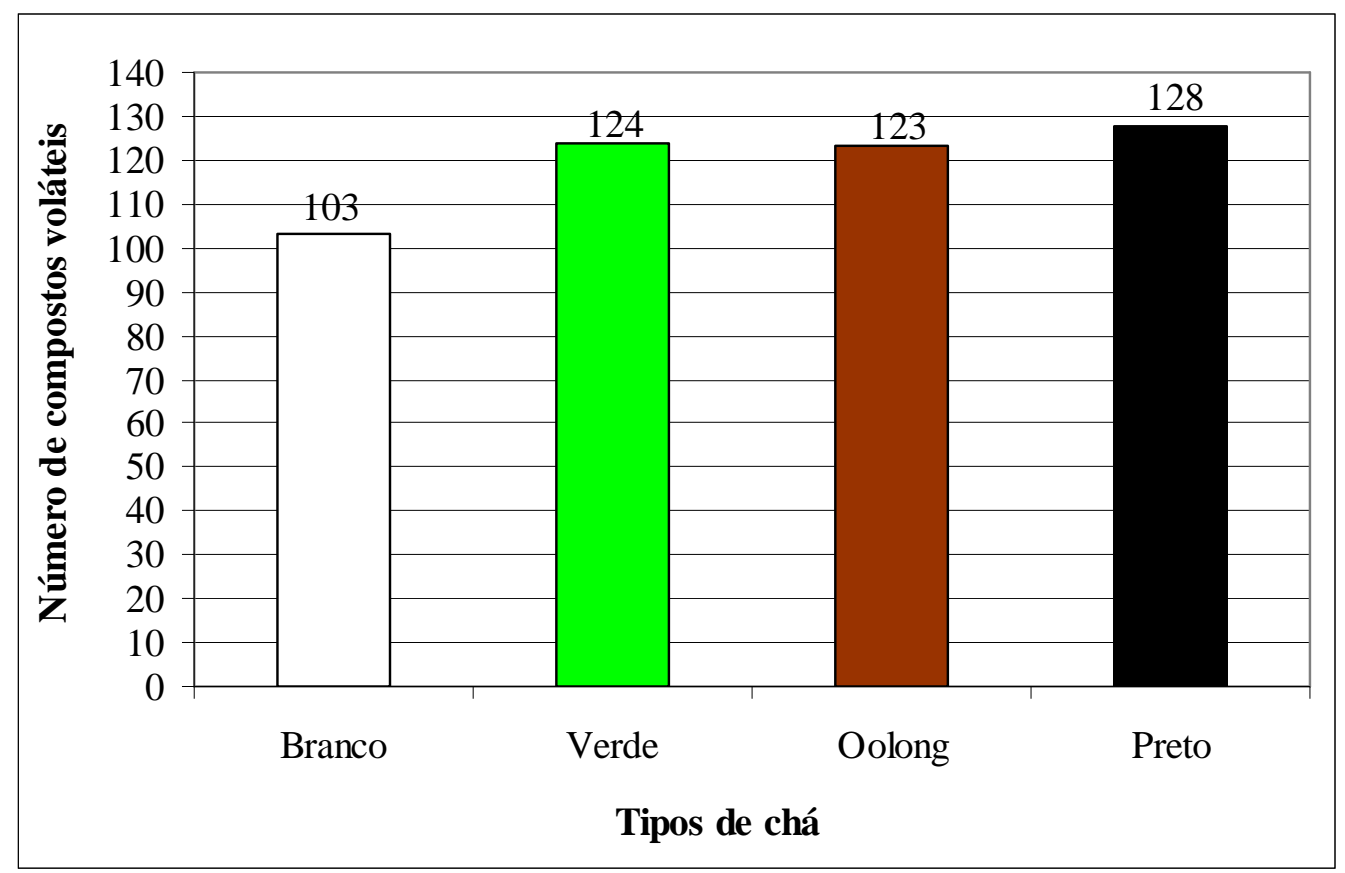

FIGURA 8 - Número de total de compostos voláteis identificados, após a irradiação, nos diferentes tipos de chá. 


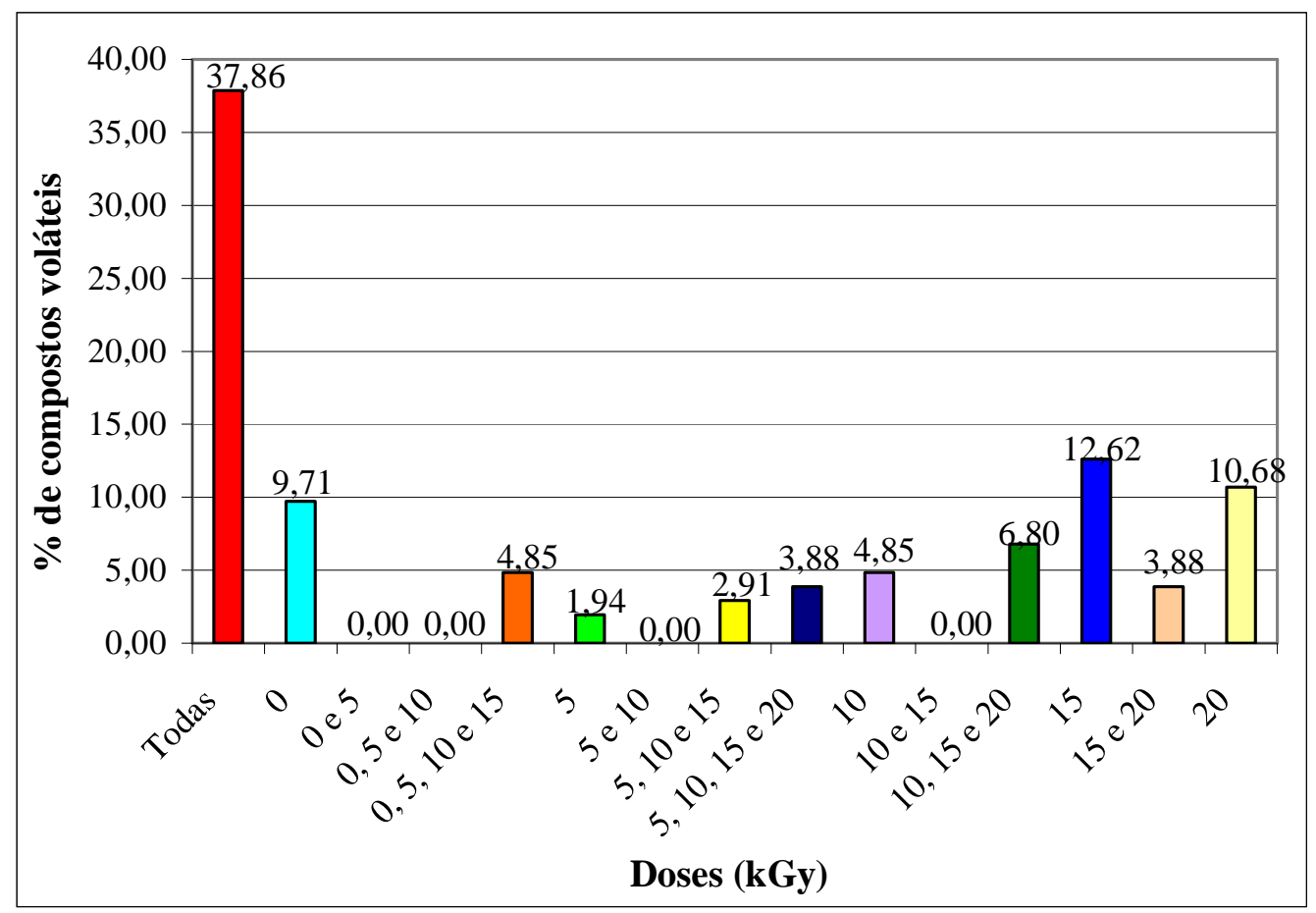

FIGURA 9 - Porcentagem de compostos voláteis identificados no chá branco nas diferentes doses de radiação.

Do total de compostos detectados, 9,71\% $(n=10)$ dos voláteis só foram encontrados nas amostras que não foram irradiadas, sendo degradas quando aplicadas a dose de $5 \mathrm{kGy}$; nenhum composto foi identificado somente nas doses controle e $5 \mathrm{kGy}$ e nas doses de 0,5 e $10 \mathrm{kGy} ; 4,85 \%(\mathrm{n}=5)$ dos voláteis foram identificados nas doses $0,5,10$ e $15 \mathrm{kGy}$, portanto foram degradados quando aplicado a dose de $20 \mathrm{kGy}$.

A dose de $5 \mathrm{kGy}$ foi responsável por formar nove novos compostos voláteis, entretanto $1,94 \%(\mathrm{n}=2)$ do total dos compostos identificados só foram idenetificados na dose de 5kGy, pois esses voláteis foram degradados quando a dose de 10kGy foi aplicada; nenhum composto foi identificado somente na dose de 5 e $10 \mathrm{kGy} ; 2,91 \%(\mathrm{n}=3)$ dos compostos voláteis foram identificados nas doses de 5, 10 e $15 \mathrm{kGy}$, ou seja, esses compostos foram degradados quando foi aplicado a dose de $20 \mathrm{kGy}$ e $3,8 \%(\mathrm{n}=4)$ dos compostos foram identificados nas doses 5, 10, 15 e 20kGy, ou seja, quatro compostos voláteis formados pela dose de $5 \mathrm{kGy}$ foram estáveis a todas as doses. 
A dose de 10kGy formou 12 novos compostos, porém 4,85\% ( $\mathrm{n}=5)$ do total de compostos foram encontrados somente na dose de 10kGy, sendo degradados quando aplicado a dose de $15 \mathrm{kGy}$; não foi identificado nenhum composto somente nas doses de 10 e $15 \mathrm{kGy}$ e $6,80 \%(\mathrm{n}=7)$ dos compostos identificados nas doses 10,15 e 20kGy, ou seja, sete compostos formados na dose de 10kGy foram estáveis quando aplicados doses superiores.

A dose de $15 \mathrm{kGy}$ foi a dose de radiação que formou mais compostos voláteis, formando 17 novos compostos, porém 12,62\% $(\mathrm{n}=13)$ foram identificados somente na dose $15 \mathrm{kGy}$, sendo degradados com a dose de $20 \mathrm{kGy}$ e $3,88 \%(\mathrm{n}=4)$ foram identificados nas doses de 15 e $20 \mathrm{kGy}$, ou seja, quatro compostos que foram formados na dose de $15 \mathrm{kGy}$ foram estáveis quando aplicado a dos de 20kGy.

Desses compostos, 57,28\% (n=59) não são compostos odoríficos e 44 substâncias possuem odor. Apesar de a radiação formar a maioria dos voláteis detectados, grande parte dos compostos que possuem odor foram encontrados em todas as doses, inclusive nas amostras controle (FIG. 10 e ANEXO A).

Dos odores encontrados naturalmente, 7 voláteis possuem odores que podem ser desagradáveis, onde a maioria deles são gorduras e portanto possuem odores de fritura e sebo, como o (Z)-2-decenal e 2,4-decadienal. A maioria deles foi resistente as doses de radiação aplicadas, pois somente o ácido oléico foi degradado quando aplicado $5 \mathrm{kGy}$ e o eicosano e heptadecano foram degradados com 20kGy (FIG. 10 e ANEXO A). A descrição se o odor é agradável ou desagradável vem da literatura (anexos). 


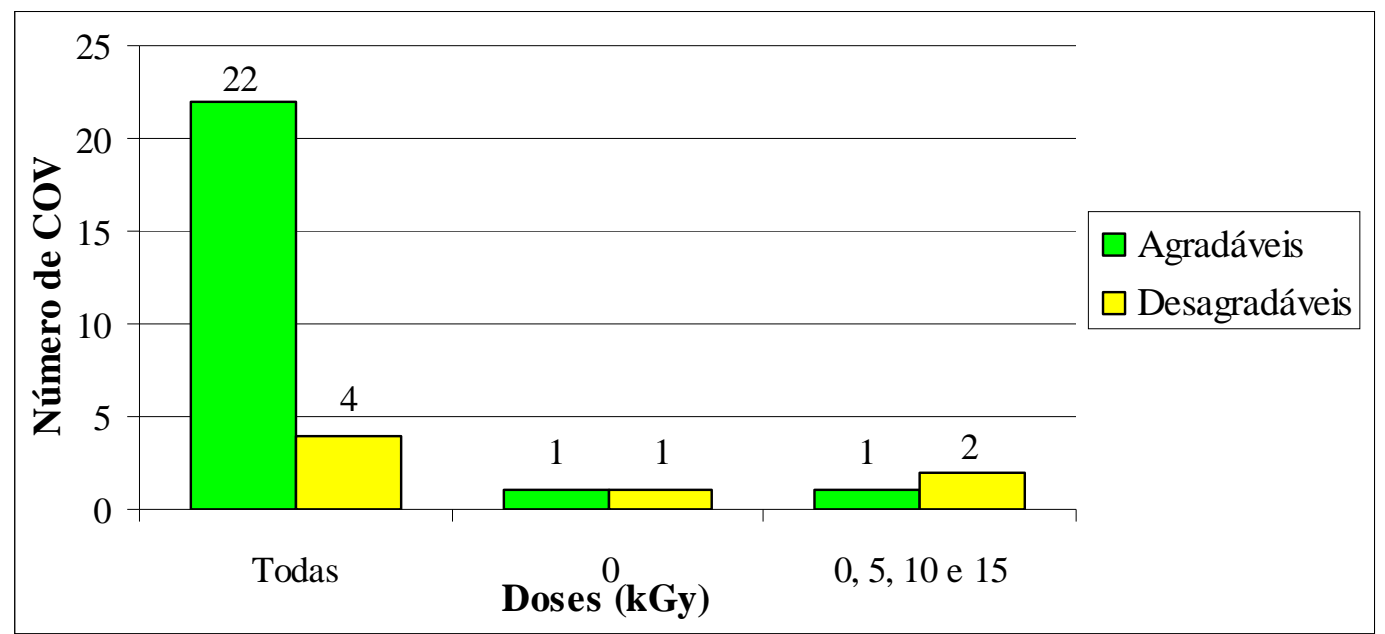

FIGURA 10 - Número de COV que possuem odores agradáveis e desagradáveis encontrados naturalmente no chá branco.

Os compostos com odores agradáveis encontrados no chá branco possuem vários tipos de odores como anis, hortelã, doce, madeira, frutas, mel e flores e a maioria também foram detectados em todas as doses. Apenas o 2-undecenal não foi possível detectar nas amostras irradiadas e o ácido octanóico não foi detectado na dose de 20kGy (ANEXO A).

Dos COV formados pela radiação, apenas 3 compostos possuem odores desagradáveis como ranço e cera e foram formados nas doses de 15 (ácido etil ester palmítico) e 20kGy (2-hexenal e docosano). Das substâncias com odores agradáveis, a maioria foram formadas pelas doses de $5 \mathrm{kGy}$ e $15 \mathrm{kGy}$ e encontram-se substâncias que possuem odores de cogumelo, frutas, cravo, amêndoa, mel, caramelo e canela (FIG. 11 e ANEXO A). 


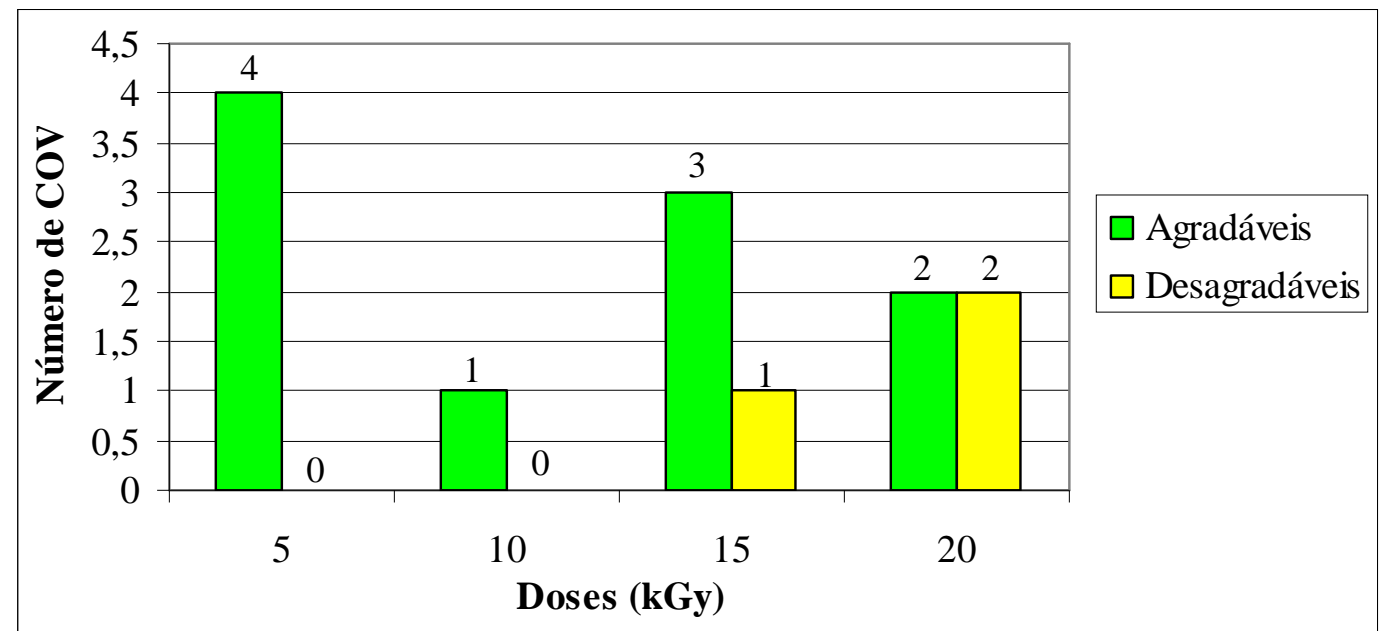

FIGURA 11 - Número de COV que possuem odores agradáveis e desagradáveis encontrados no chá branco irradiado com diversas doses.

De um modo geral, a quantidade de cada composto volátil aumentou conforme a dose de radiação aumentou. Na FIG. 12 é mostrado o comportamento de 10 compostos encontrados no chá branco. Entretanto, na dose de 15kGy há uma diminuição na quantidade da maioria dos compostos escolhidos e na dose de 20kGy a quantidade aumenta para valores próximos de $10 \mathrm{kGy}$, como a $\beta$-ionona, e em alguns compostos a quantidade é maior, como na dihidro-actinidiolida.

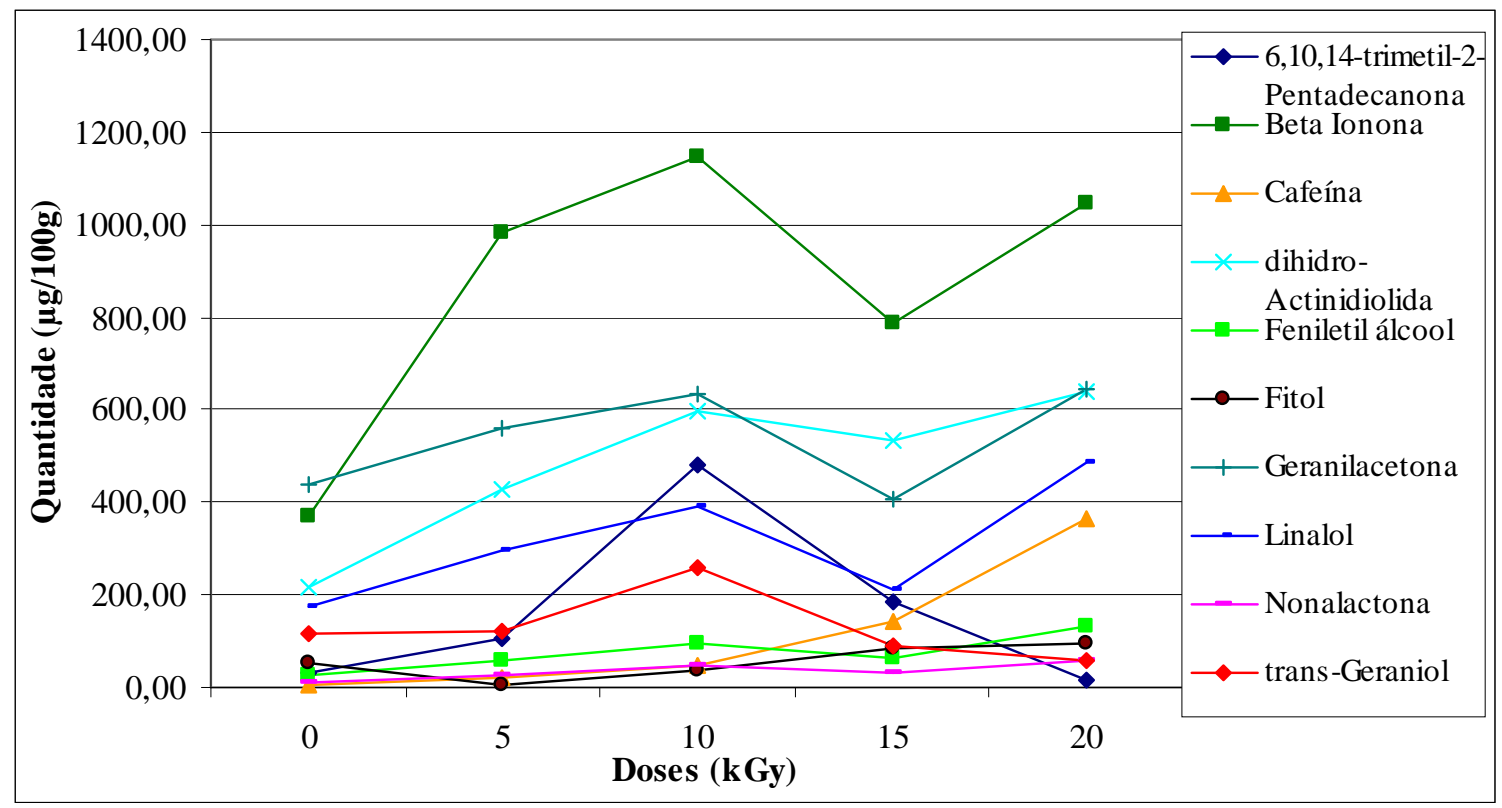

FIGURA 12 - Distribuição da quantidade de dez COV, em $\mu \mathrm{g} / 100 \mathrm{~g}$ de chá branco, nas diferentes doses de radiação. 
A escolha dos compostos se baseou na diferença da quantidade entre as amostras não irradiadas com as irradiadas, pois não foi encontrado nenhum trabalho na literatura para esse tipo de chá.

Apesar das diferenças encontradas entre a amostra controle e as irradiadas, a análise de componentes principais mostrou que, embora a amostra controle e a irradiada com 20kGy estarem levemente deslocadas em relação as outras doses, não houve diferença entre elas. Isto significa que não houve diferença entre o chá branco não irradiado e os chás irradiados com 5, 10, 15 e 20kGy (FIG. 13).

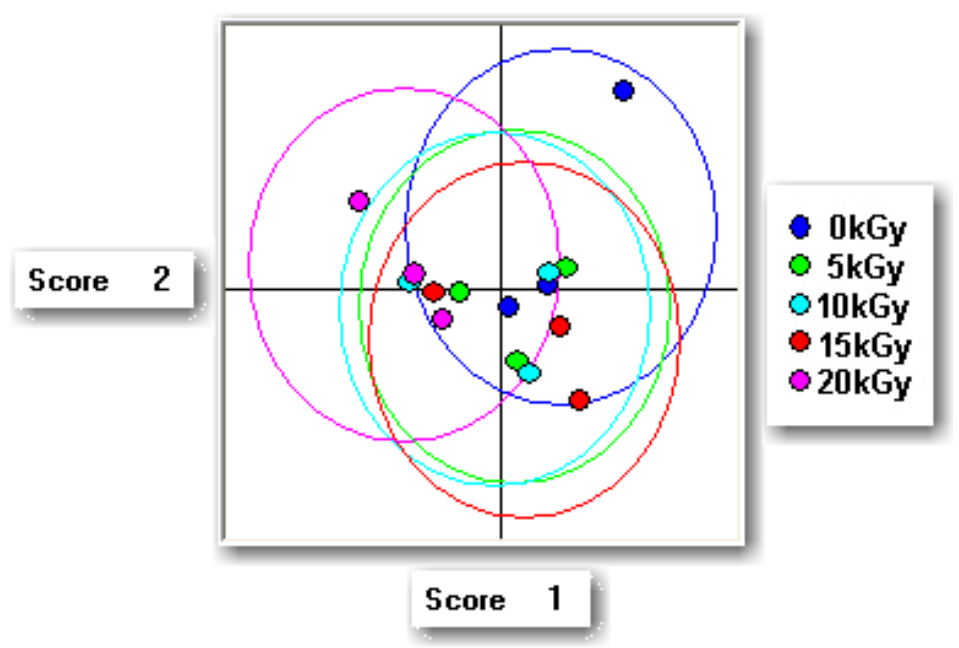

FIGURA 13 - Análise de componentes principais do chá branco irradiado com diferentes doses.

O chá verde foi o chá que sofreu a maior influência dos efeitos da radiação na formação de novos compostos, gerando um aumento de 66,12\% (n=82) de voláteis identificados em relação à amostra controle e apenas 21,77\% (n=27) dos voláteis encontrados naturalmente foram resistentes a todas as doses de radiação (FIG. 14, ANEXO B). 


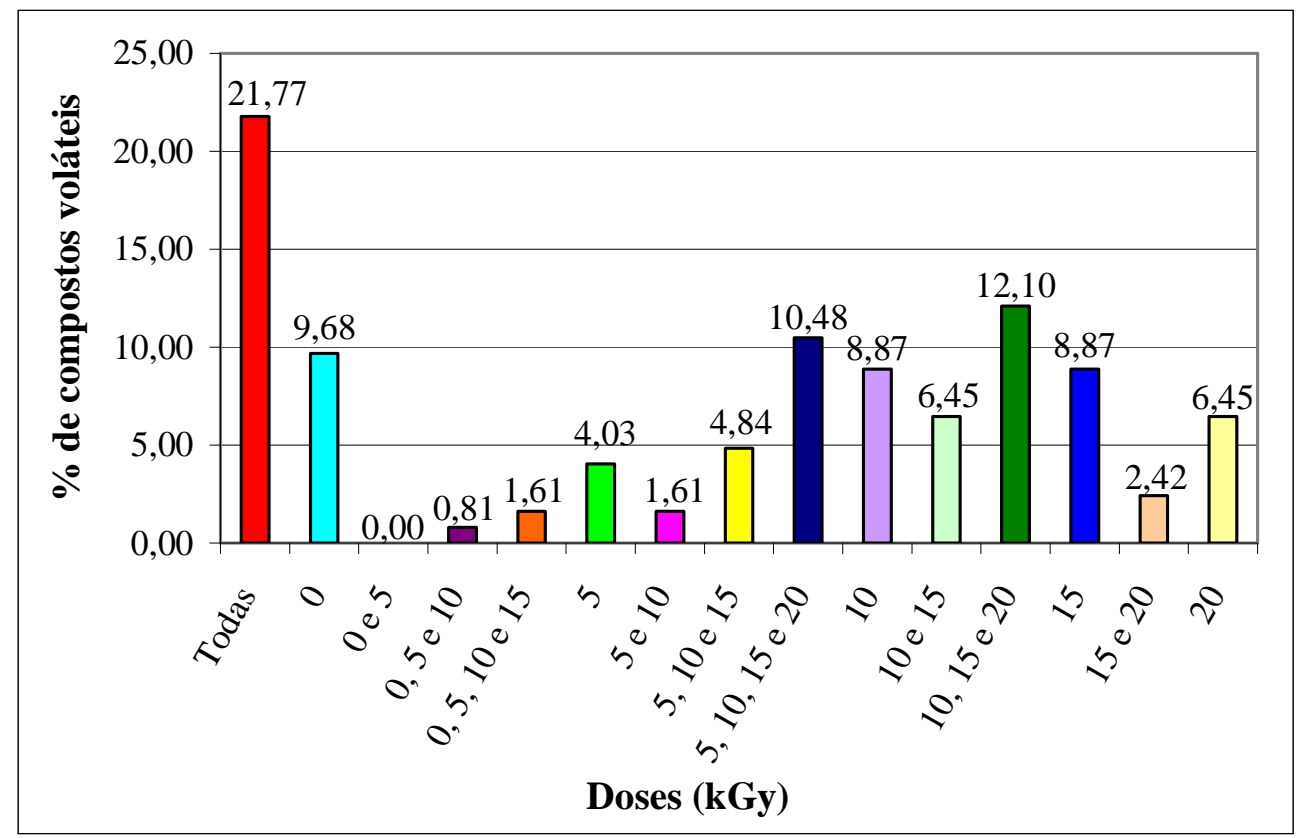

FIGURA 14 - Porcentagem de compostos voláteis identificados no chá verde nas diferentes doses de radiação.

Do total de voláteis encontrados, a dose de 10kGy formou 27,42\% $(n=34)$ de novos compostos, sendo a dose que mais formou voláteis em comparação com as outras doses, sendo que a maioria desses compostos foram estáveis também quando aplicado as doses maiores. O mesmo aconteceu na dose de $5 \mathrm{kGy}$, onde a maioria dos voláteis formados nessa dose também foram estáveis quando submetidas a dose de 20kGy.

Desses COV, 59,68\% (n=74) não possuem qualquer tipo de odor e 50 voláteis possuem algum odor característico. Assim como no chá branco, a maioria dos compostos odoríficos foi resistente as doses de radiação. Apenas quatro compostos voláteis (aldeído mirístico, cis-geraniol, octadecanal, óxido cis-linalol) foram degradados quando submetidos à radiação e um composto volátil (óxido beta-cariofileno) degradou na dose de 20kGy (FIG. 15, ANEXO B). 


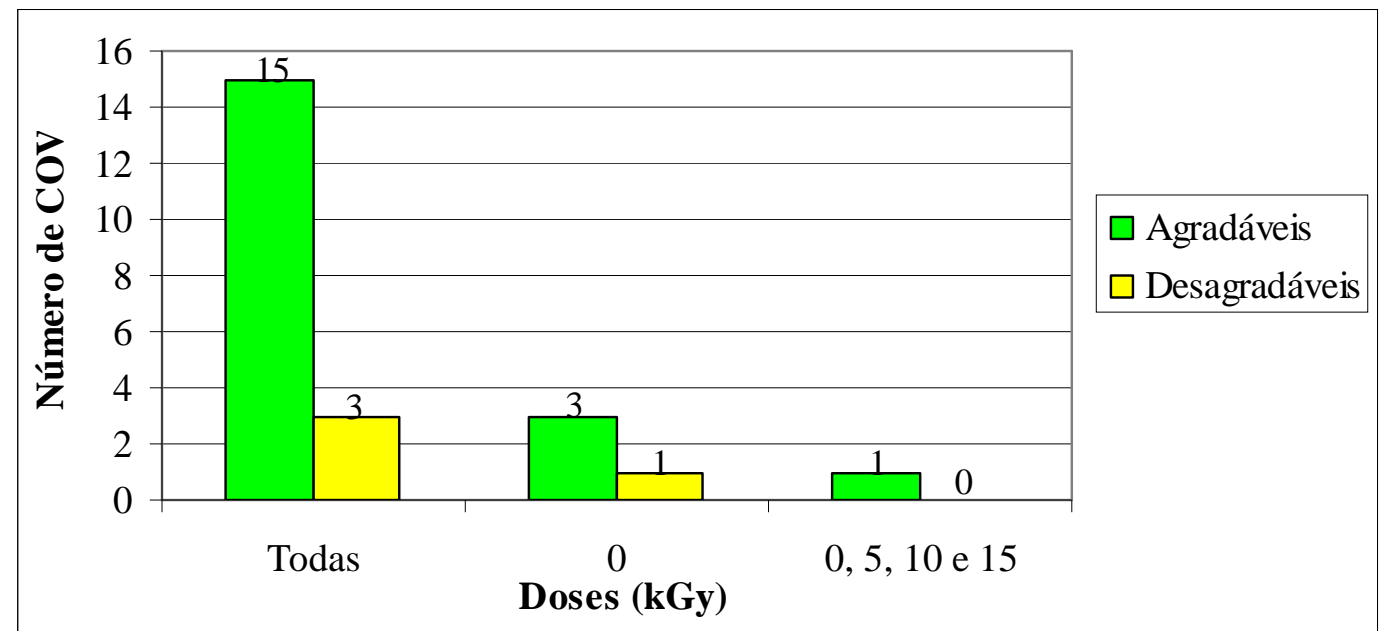

FIGURA 15 - Número de COV que possuem odores agradáveis e desagradáveis encontrados naturalmente no chá verde.

Entre os odores agradáveis estão os odores de frutas, cogumelo, doce, grama, flores, anis, hortelã e madeira. Entre os odores desagradáveis estão os cheiros de sebo, óleo, gordura e alcano (ANEXO B).

Das amostras irradiadas, a grande parte dos compostos formados foram agradáveis e a dose de $10 \mathrm{kGy}$ foi a que formou a maioria desses compstos odoríficos. Já as doses de 15 e 20kGy formaram juntas cinco odores desagradáveis (ácido butanóico, Docosano, Heneicosano, trans-2-decenal e Tricosano) que estão relacionados a oxidação de gorduras e não formou nenhum odor agradável (FIG. 16 e ANEXO B).

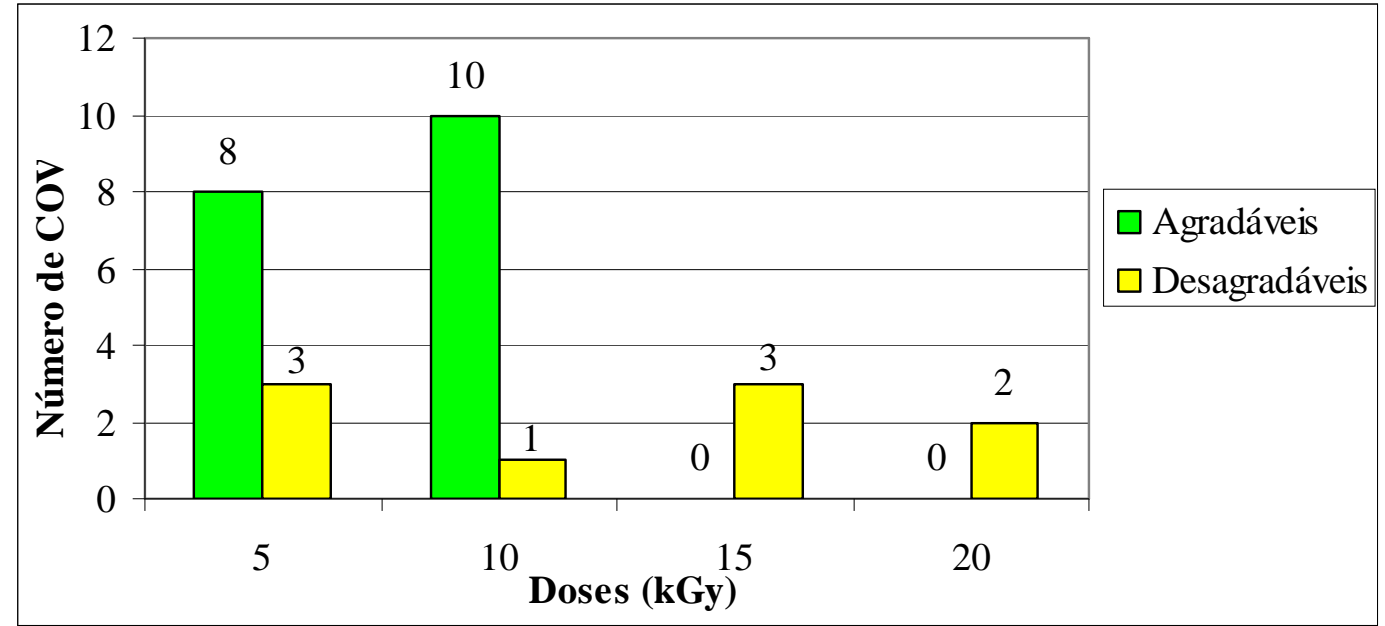

FIGURA 16 - Número de COV que possuem odores agradáveis e desagradáveis encontrados no chá verde irradiado com diversas doses. 
Entre os odores agradáveis estão os cheiros de frutas (ex. pêssego), flores (ex. lírio do vale), madeira, pepino, cravo, amêndoa, mel e caramelo e entre os odores desagradáveis estão os cheiros de ranço, fritura, gordura, suor, remédio e fumaça (ANEXO B).

Em seu trabalho, Yamaguchi e Shibamoto (1981) conseguiram descrever 79 compostos voláteis no chá verde, sendo que a maioria também foi encontrado nesse trabalho. Eles relatam ainda os 10 voláteis que são mais encontrados no chá verde e desses COV, 8 também foram encontrados. Hattori et al.(2005) identificaram os 11 compostos voláteis que mais contribuem para o odor do chá verde (cis-1,5-octadien-3-ona; cis-3hexenol; linalol; 2-etil-3,5-dimetilpirazina; decanal; 2-acetil-3,5-dimetilpirazina; 3-metilionona-2,4,diona; geraniol; $\beta$-ionana; 2-acetilpirrole e indole) entretanto apenas 3 desses COV foram encontrados (geraniol, linalol e $\beta$-ionona).

Muitos fatores podem influenciar na detecção de compostos voláteis, entre eles estão o tipo de coluna usado, os métodos de extração, a programação do cromatógrafo, o tipo e quantidades de biblioteca, entre outros (Collins, 2006; Willet, 1993). Por essa razão, é que não foi possível detectar os mesmos COV de outros trabalhos.

Na FIG. 17 é mostrado o comportamento dos COV que este trabalho teve em comum com os dois trabalhos citados anteriormente.

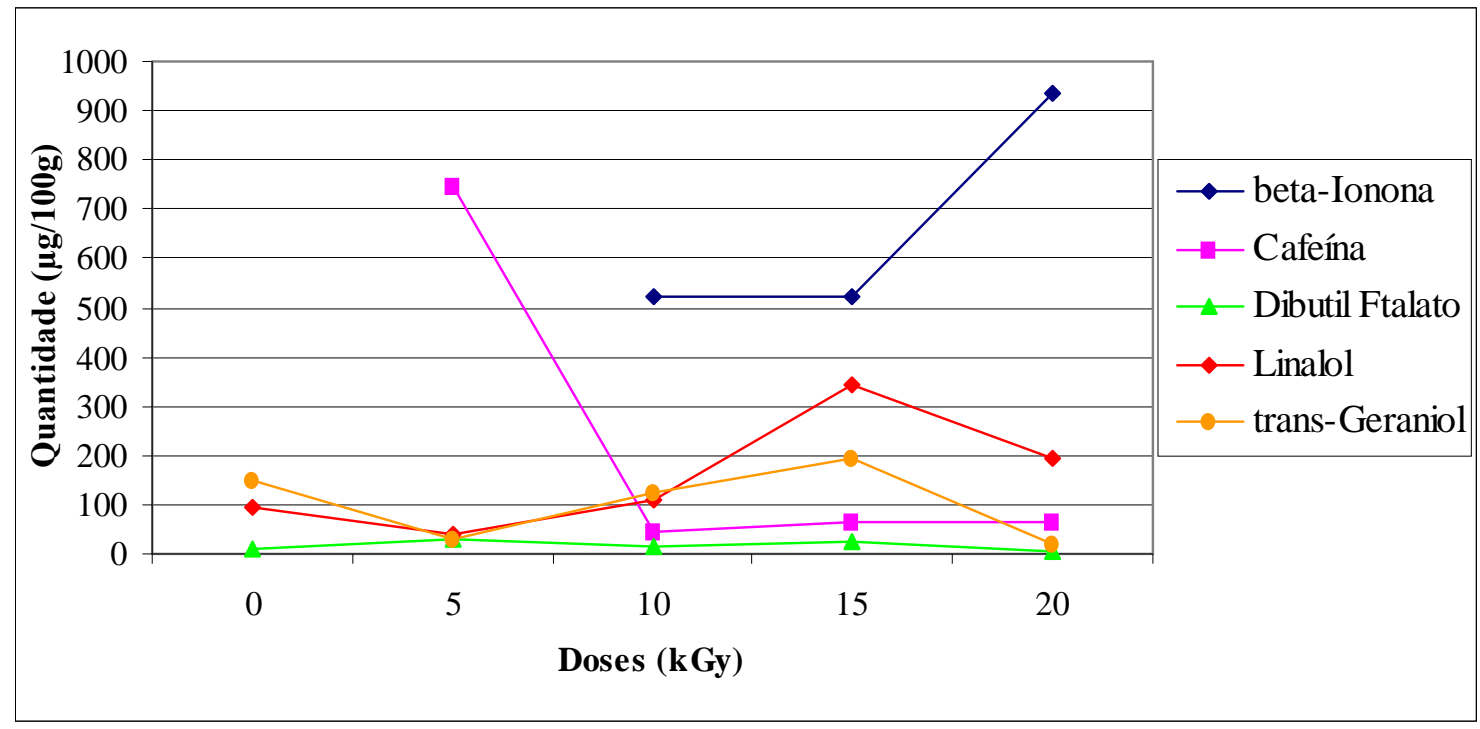

FIGURA 17 - Distribuição da quantidade de cinco COV, em $\mu \mathrm{g} / 100 \mathrm{~g}$ de chá verde, nas diferentes doses de radiação. 
Para o chá verde, a análise de componentes principais demonstrou um leve desvio da amostra controle para as outras doses e um desvio menor das doses de 10 e 20kGy em relação as doses 5 e $15 \mathrm{kGy}$. Porém esse desvio não pode ser considerado que existe uma diferença entre as doses (FIG. 18). Portanto, para o chá verde, não houve diferença entre as amostras irradiadas com diversas doses para as amostras não irradiadas.

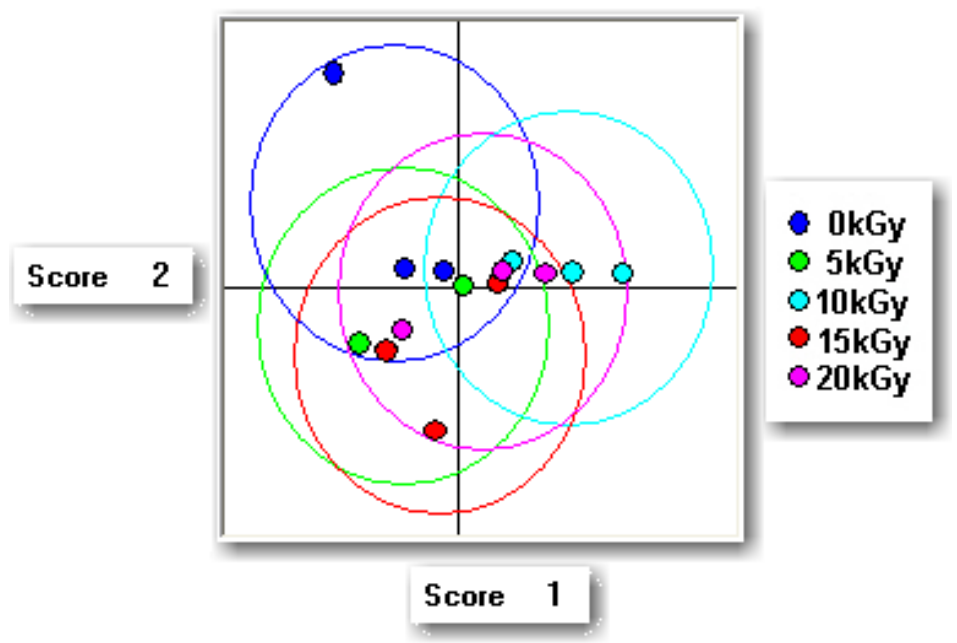

FIGURA 18 - Análise de componentes principais do chá verde irradiado com diferentes doses.

O chá oolong apesar de sofrer um tratamento enzimático parcial, foi o segundo chá que sofreu a menor interferência da radiação no aumento da formação de novos voláteis. Nesse chá foi possível detectar 49,59\% ( $n=61)$ de novos compostos após a irradiação e 30,08\% (n=37) dos compostos encontrados naturalmente também foram encontrados depois da irradiação (FIG. 19, ANEXO C).

Com exceção dos voláteis encontrados em todas as doses, os compostos encontrados nas amostras controle representam 20,33\% $(n=25)$ do total de compostos voláteis e a maioria dessas substâncias foram degradadas quando submetidas à irradiação. O mesmo fenômeno pôde ser observado com as doses 5, 10 e $15 \mathrm{kGy}$, onde a maioria dos compostos formados por essas doses foram degradados quando empregado doses maiores de radiação. 
Nos voláteis formados nas amostras irradiadas, a dose de 10kGy formou $15,45 \%(\mathrm{n}=19)$ do total de compostos identificados, uma quantidade parecida com as doses de $5 \mathrm{kGy}$ e $15 \mathrm{kGy}(13 \%, \mathrm{n}=16 ; 13,82 \%, \mathrm{n}=17$ respectivamente $)$.

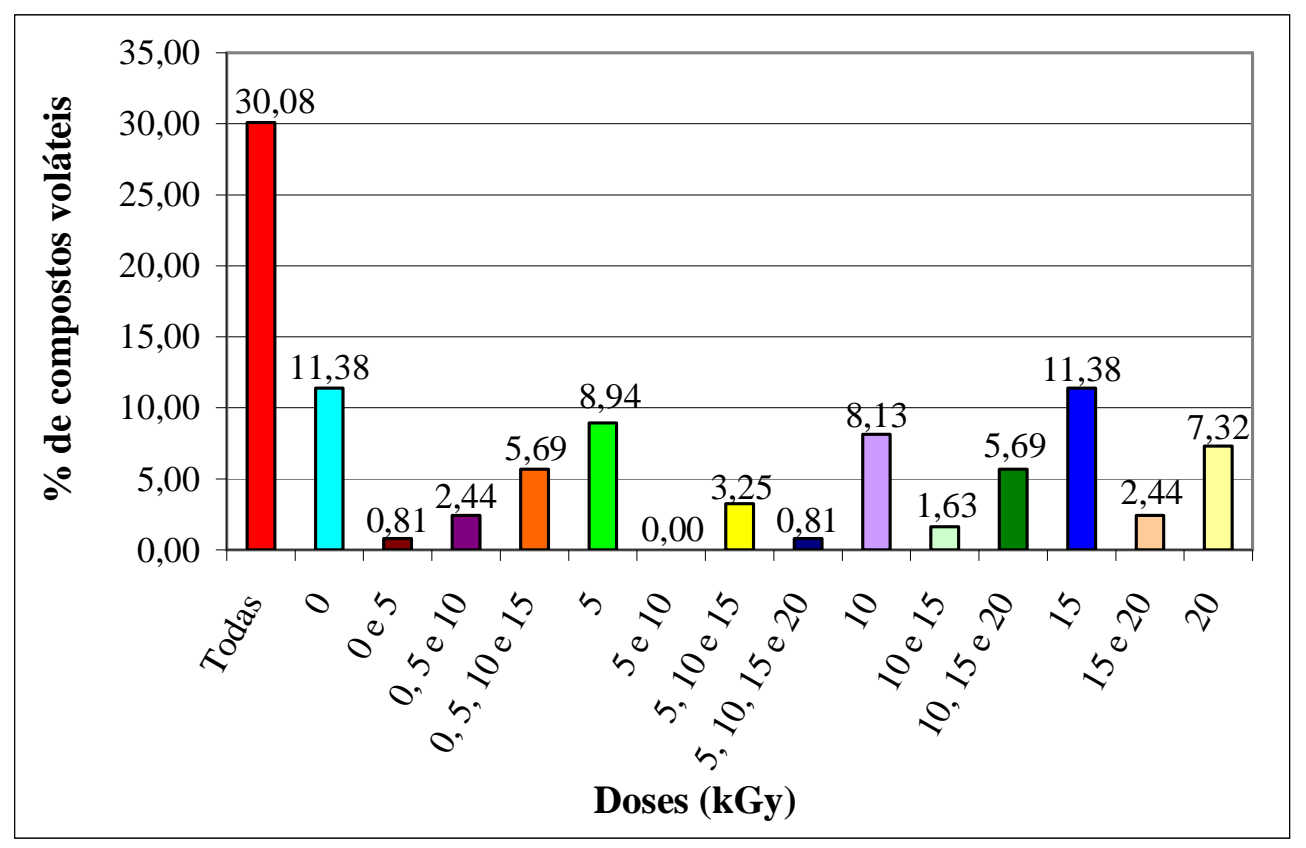

FIGURA 19 - Porcentagem de compostos voláteis identificados no chá oolong nas diferentes doses de radiação.

Desses compostos, 65,04\% (n=80) não são compostos odoríficos e 43 substâncias possuem odor. Apesar de a radiação formar a maioria dos voláteis detectados, grande parte dos compostos que possuem odor foram encontrados em todas as doses, inclusive nas amostras controle (FIG. 20 e ANEXO C).

Dos odores encontrados naturalmente, 7 voláteis possuem odores que podem ser desagradáveis, como gordura, fritura, queimado e naftalina, pois grande parte vem de gorduras presente nesse chá. Três desses compostos voláteis foram resistentes a todas as doses aplicadas (3-metil-indole, 6,10,14-trimetil-2-pentadecanona e indole), dois foram degradados com a radiação (ácido oléico, undecano) e um COV foi degradado com 15 kGy (E,E-2,4-heptadienal) e outro com 20kGy (octadecano) (FIG. 20 e ANEXO C). 
Os compostos com odores agradáveis encontrados no chá oolong possuem vários tipos de odores como amêndoa, caramelo, flores, doce, grama, hortelã, frutas, algas, cravo e mel e a maioria também foram detectadas em todas as doses. Os COV $\beta$ dodecalactona, geranial e melilotal não foram possíveis de detectar nas amostras irradiadas e o 1,1,6-trimetil-1,2-dihidro-naftaleno, $\beta$-ciclocitral e eugenol não foram detectados na dose de 20kGy (ANEXO A).

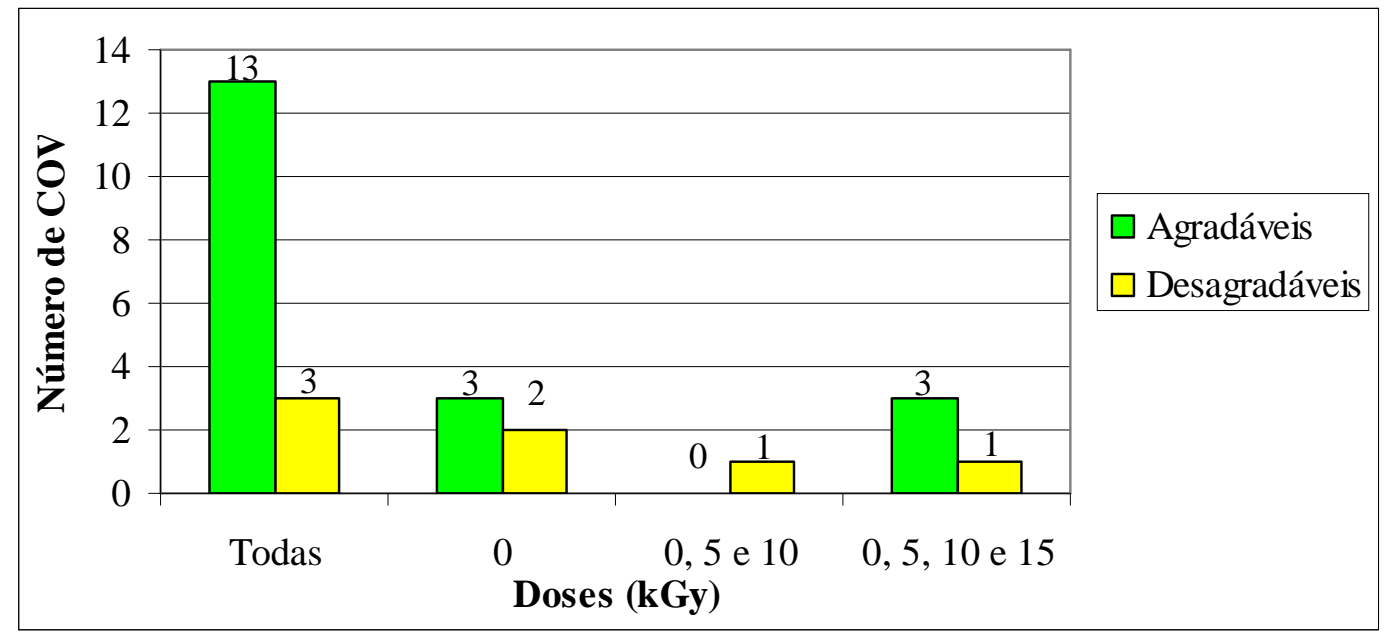

FIGURA 20 - Número de COV que possuem odores agradáveis e desagradáveis encontrados naturalmente no chá oolong.

Nesse chá, cada dose de radiação formou a mesma quantidade tanto de odores agradáveis quanto de odores desagradáveis, com exceção da dose de $15 \mathrm{kGy}$, que foi a dose que mais formou compostos voláteis com odor (FIG. 21). Das substâncias com odores agradáveis encontram-se odores de noz, pão, pimenta, amêndoa, caramelo, flores e hortelã e de odores desagradáveis estão os cheiros de gordura, fritura, ranço, ácido, remédio, fumaça e sebo (ANEXO C). 


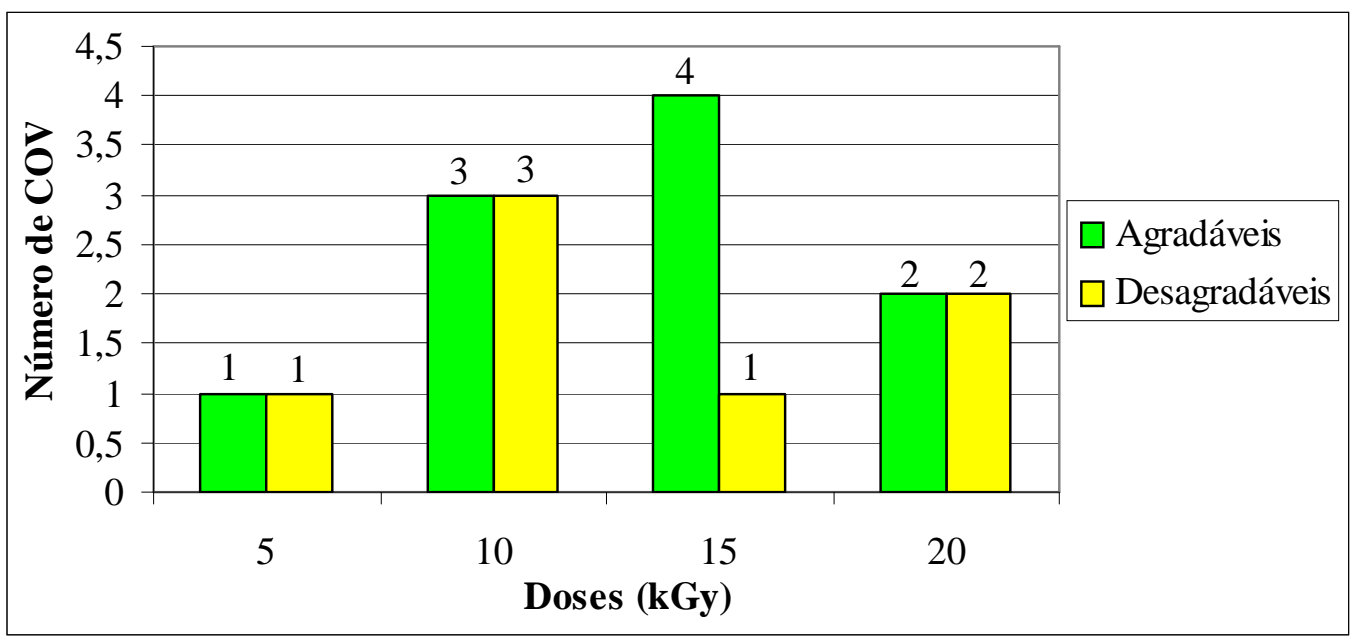

FIGURA 21 - Número de COV que possuem odores agradáveis e desagradáveis encontrados no chá oolong irradiado com diversas doses.

O chá oolong, por sofrer ação enzimática parcial, ele conserva características tanto do chá verde, quanto do chá preto, apesar de que esses dois tipos de chá também possuem alguns compostos voláteis semelhantes, já que derivam da mesma planta. Rawat et al. (2007) descreve os 10 compostos que estão em maior quantidade no chá preto (geraniol; $\beta$-ionona; nerolidol; 6,10,14-trimetil-2-pentadecanona; linalol; $\alpha$-damascona; $\alpha$ irona; fitol; ácido hexanóico e 2,6,6-trimetil-2-hidroxiciclohexanona).

Na FIG. 22 é mostrado o comportamento dos COV que o chá oolong tem em comum com o chá verde e com o chá preto nas diferentes doses de radiação. Para esses compostos, o comportamento perante a radiação variou de COV para COV. A quantidade de indole diminuiu com a aplicação de $5 \mathrm{kGy}$ e aumentou conforme houve o aumento das doses. Para o fitol, cafeína e 6,10,14-trimetil-2-pentadecanona a dose de 5kGy aumentou suas quantidades, entretanto a partir de $10 \mathrm{kGy}$ a quantidades desses compostos diminuíram, com exceção da cafeína que teve sua quantidade aumentada com a dose de 20kGy. Para os outros compostos a quantidade aumentou com o aumento da dose e a partir de $10 \mathrm{kGy}$, conforme o aumento de dose as quantidades diminuíram.

Apesar de não ter sido encontrado nenhum trabalho que quantificasse os COV do chá oolong, a literatura possui estudos sobre a identificação dos componentes voláteis 
que constitui esse tipo de chá. Os resultados encontrados nesse estudo estão de acordo com os trabalhos realizados por Takeo (1984) e Wang et al. (2008).

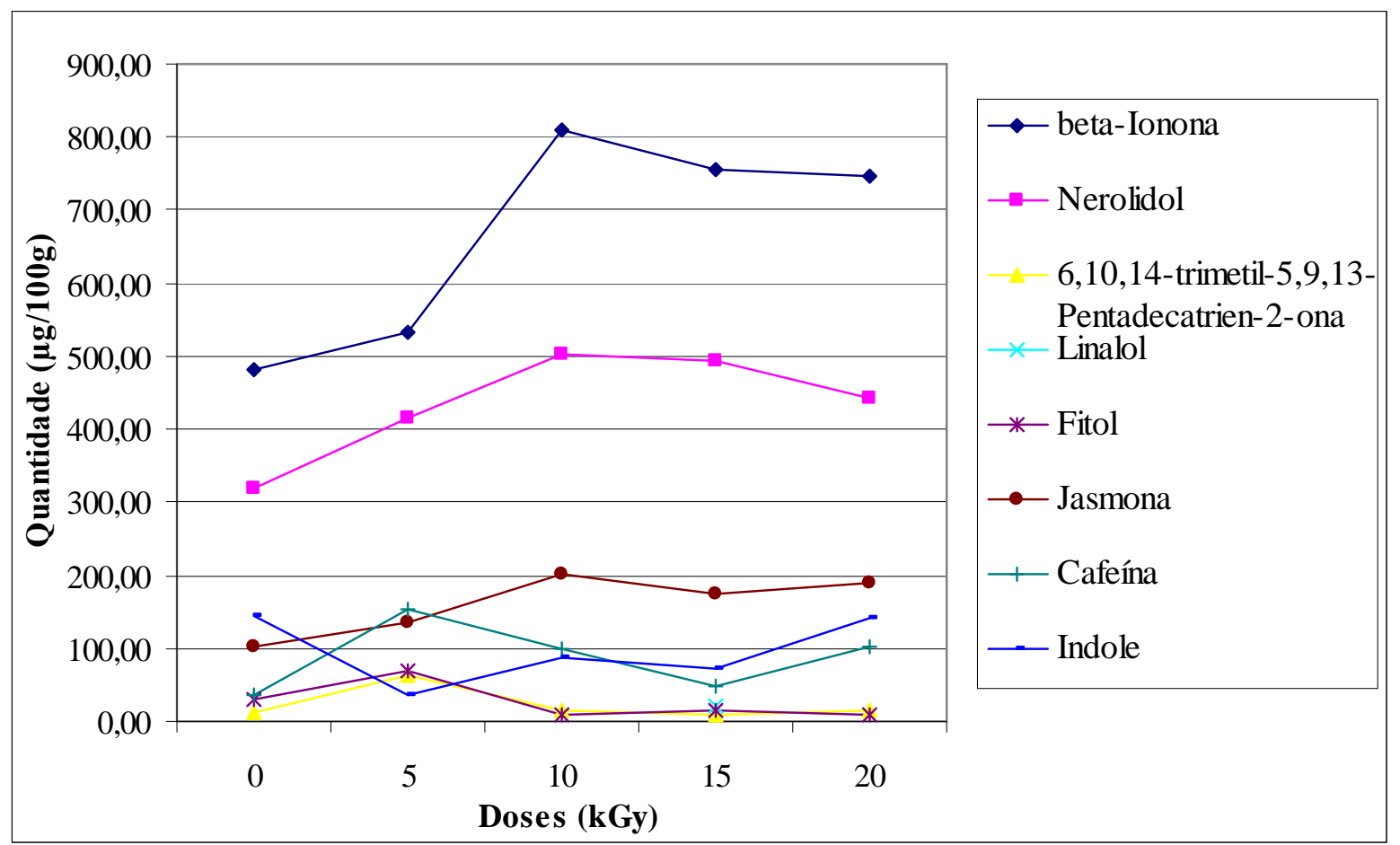

FIGURA 22 - Distribuição da quantidade de sete COV, em $\mu \mathrm{g} / 100 \mathrm{~g}$ de chá oolong, nas diferentes doses de radiação.

A análise de componentes principais revelou o segundo maior afastamento entre doses, principalmente entre as doses 5 e $15 \mathrm{kGy}$, podendo ser considerado uma diferença entre essas duas doses. As doses de 15 e $20 \mathrm{kGy}$ mostraram ter um perfil de componentes principais mais parecidas com a amostra controle, enquanto a dose de 10kGy mostra ter um perfil mais parecido com a dose de $5 \mathrm{kGy}$. A dose de $20 \mathrm{kGy}$ foi a dose que mais teve semelhanças com todas as doses (FIG. 23). 


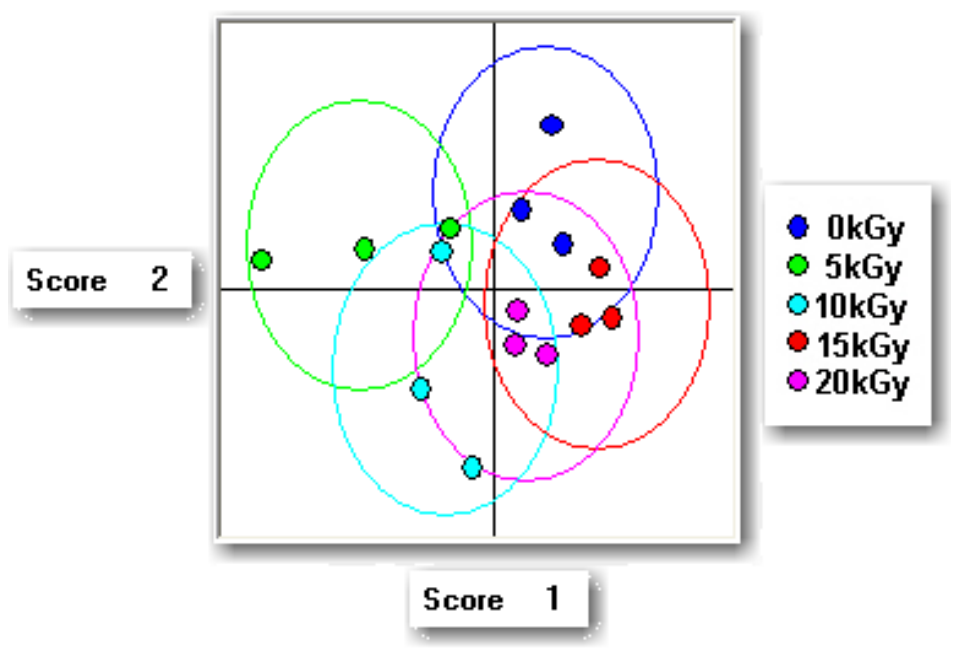

FIGURA 23 - Análise de componentes principais do chá verde irradiado com diferentes doses.

O chá preto foi o segundo chá que sofreu a maior interferência da radiação na formação de novos voláteis $(60,94 \%, n=78)$, porém foi o chá onde se obteve a menor quantidade de compostos estáveis à radiação. Apenas $17,97 \% \quad(n=23)$ do total de compostos identificados não foram degradados quando empregado à radiação ionizante (FIG. 24 e ANEXO D).

Do total de compostos formados, a dose de $5 \mathrm{kGy}$ foi responsável em formar a grande parte $(40,62 \%, \mathrm{n}=52)$ dos compostos identificados e a maioria desses compostos, $30,47 \%(\mathrm{n}=39)$ do total, foram degradados quando submetidos a dose de 10kGy e conforme há o aumento da dose, menor é a formação de novos compostos voláteis. O total de compostos formados nas doses de 15 e $20 \mathrm{kGy}$, chegou a $10 \%$ do total de compostos identificados. Isso pode ser explicado devido ao tratamento enzimático que a $C$. sinensis é submetida para que se obtenha o chá preto (FIG. 24 e ANEXO D). 


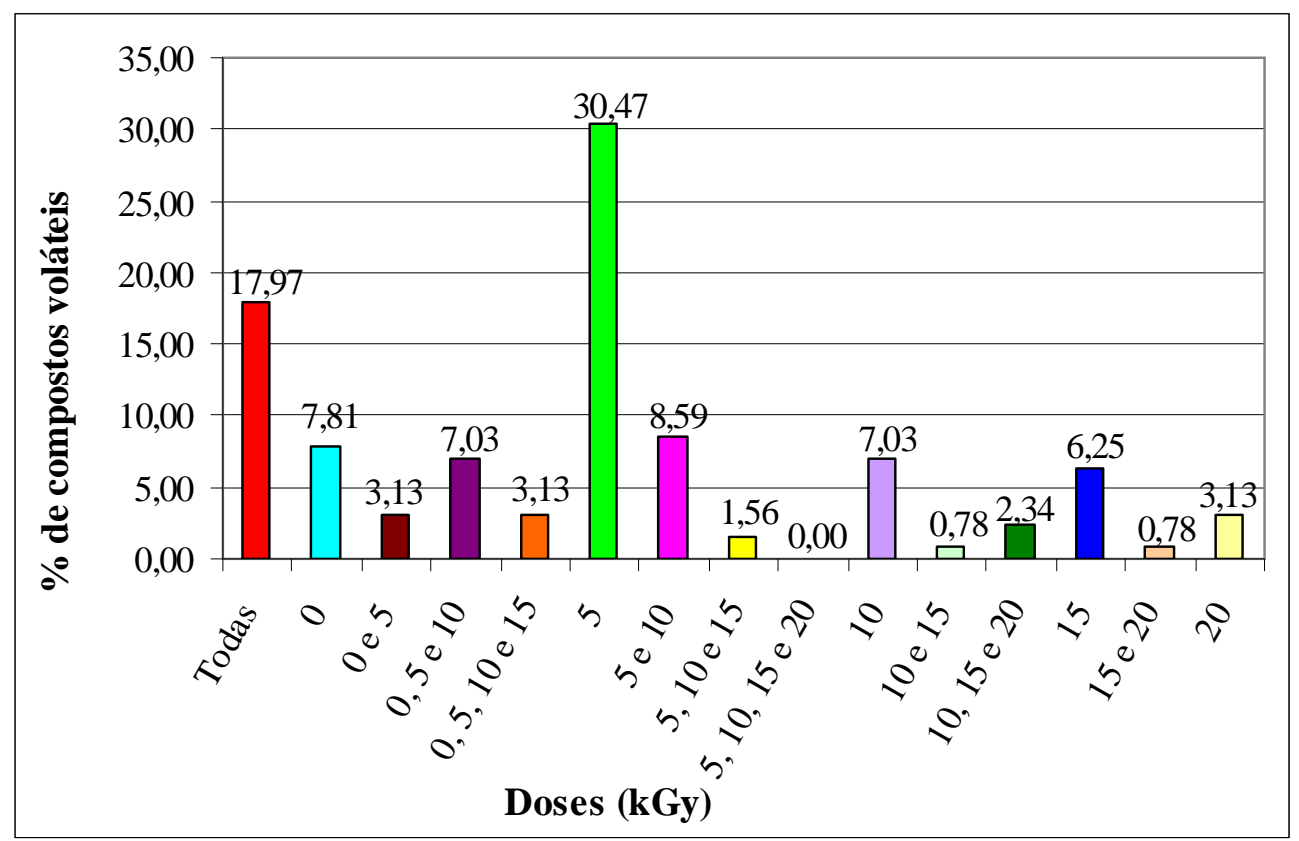

FIGURA 24 - Porcentagem de compostos voláteis identificados no chá preto nas diferentes doses de radiação.

Desses compostos, 62,5\% (n=80) não possuem qualquer tipo de odor e 48 substâncias são compostos odoríficos. Dos COV encontrados naturalmente, a maioria dos compostos foram resistentes a todas as doses de radiação e grande parte foram de odores agradáveis com cheiros de madeira, cravo, flor, hortelã, mel, alga e framboesa (FIG. 25 e ANEXO D).

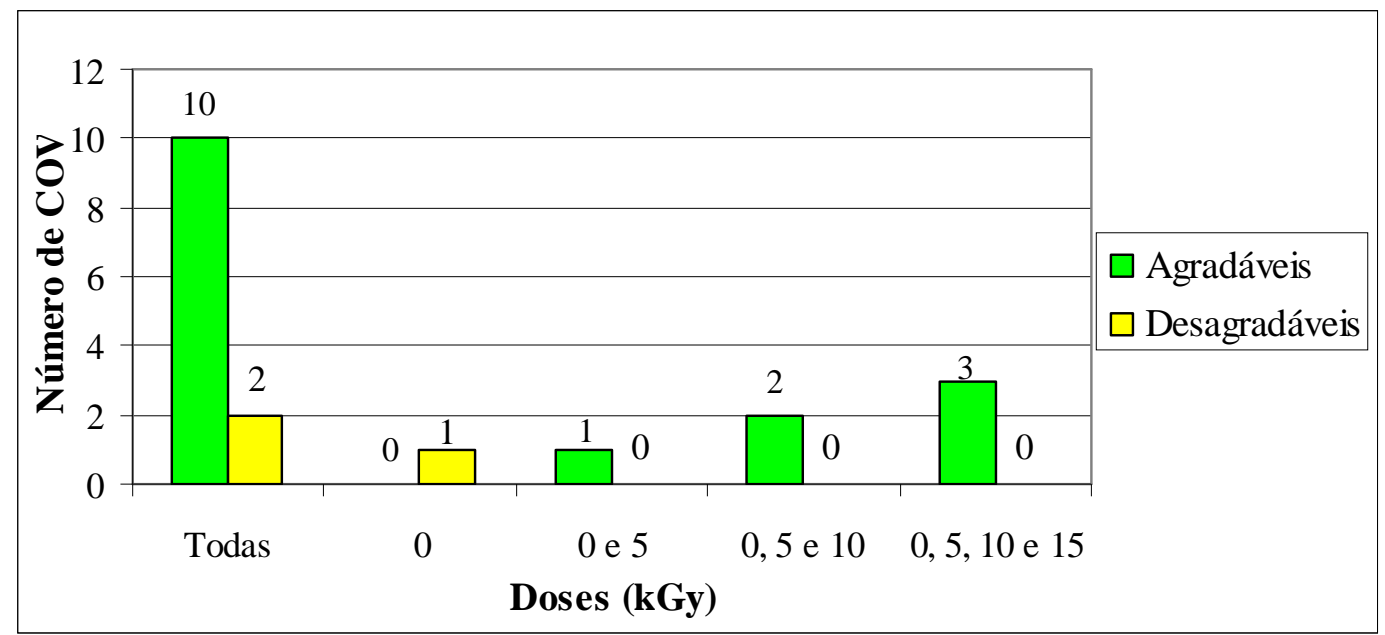

FIGURA 25 - Número de COV que possuem odores agradáveis e desagradáveis encontrados naturalmente no chá preto. 
Entre os odores que foram degradados com a radiação, apenas um ([+]aromadendreno) não foi resistente a doses acima de 10kGy, dois ( $\alpha$-tolualdeído e 6,10,14trimetil-5,9,13-pentadecatrien-2-ona) foram degradados com $15 \mathrm{kGy}$ e quatro (4vinilguaiacol, cis-geraniol e óxido cis-linalol) com a aplicação de 20kGy (ANEXO D).

Dos compostos voláteis com odores desagradáveis foram identificados apenas dois COV foram resistentes a todas as doses (ácido etil éster palmítico e eicosano) e somente um foi degradado com a mínima dose de radiação (2,4-decadienal). Entre os odores desagradáveis estão os cheiros de cera, gordura e alcano (FIG. 26 e ANEXO D).

A dose de 5kGy além de formar mais COV, também foi a dose que mais formou compostos que possuem odor e a maioria foram odores agradáveis (FIG. 26). Juntas, as outras doses formaram um pouco mais de um terço dos odores agradáveis detectados (coumarina, epoxilinalol, isoeugenol e valenceno que foram formados pela dose de $10 \mathrm{kGy}$ e o $\alpha$-gurjuneno pela dose de $15 \mathrm{kGy}$ ) (ANEXO D).

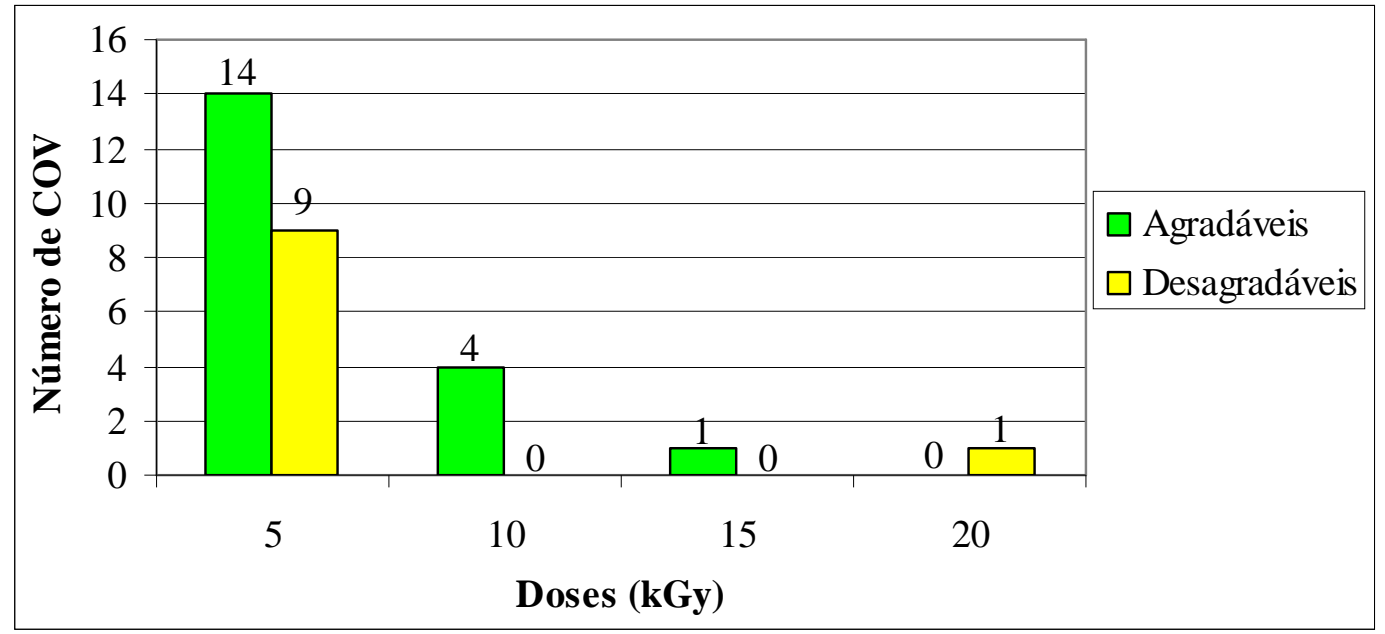

FIGURA 26 - Número de COV que possuem odores agradáveis e desagradáveis encontrados no chá preto irradiado com diversas doses.

Entre os compostos com odores desagradáveis, a dose de 20kGy formou apenas um COV ([E,E]-2,4-decadienal) e a dose de 5kGy formou os outros compostos detectados. Os voláteis identificados possuem odores de fritura, ranço, naftalina, fumaça e remédio (ANEXO D). 
Em seu trabalho, Borse et al. (2002) também descreve os 25 COV mais comuns em chá preto, porém os 10 compostos mais abundantes ( $\alpha$-terpineol, 2-hexenal, fenilacetaldeído, linalol, cis-geraniol, fitol, $\beta$-ionona, metilsalicilato, óxido de linalol e feneletilálcool) não são todos iguais àqueles descritos por Rawat et al., 2007, isso se deve principalmente ao tipo de amostra que vieram de regiões e tempos diferentes. Esse fato pode ser comprovado neste trabalho, pois não foi encontrado o composto volátil metilsalicilato e o 2-hexenal só foi detectado quando uma dose de radiação foi aplicada.

Na FIG. 27 é mostrado o comportamento dos 9 COV que este trabalho teve em comum com Borse et al.(2002) nas diferentes doses de radiação.

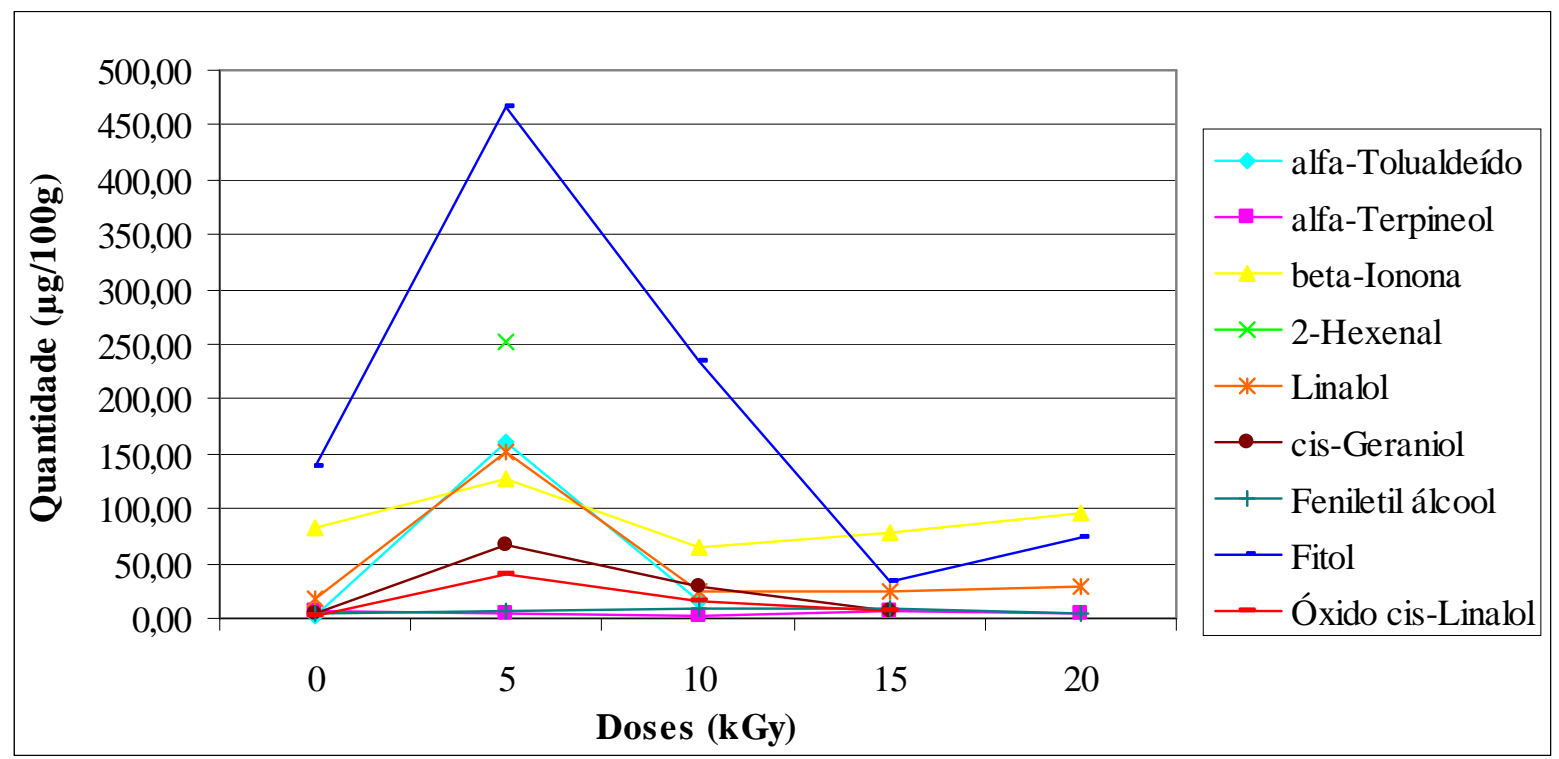

FIGURA 27 - Distribuição da quantidade de nove COV, em $\mu \mathrm{g} / 100 \mathrm{~g}$ de chá preto, nas diferentes doses de radiação.

Com exceção do 2-hexenal, todos os compostos tiveram sua quantidade aumentada na dose de $5 \mathrm{kGy}$ e diminuída na dose de $10 \mathrm{kGy}$. A partir de $15 \mathrm{kGy}$ o $\alpha$ tolualdeído já não foi detectado e um a $\beta$-ionona teve sua concentração levemente aumentada. Com 20kGy, o cis-geraniol e óxido cis-linalol não foram detectados e a concentração de fitol aumentou.

A análise de componentes mostrou o maior afastamento entre as doses, principalmente das doses de 5 e 10kGy em relação a dose controle, mostrando uma 
diferença significativa. Já as doses 15 e 20kGy mostraram ter um perfil de componentes principais muito parecidas com a amostra controle (FIG. 28).

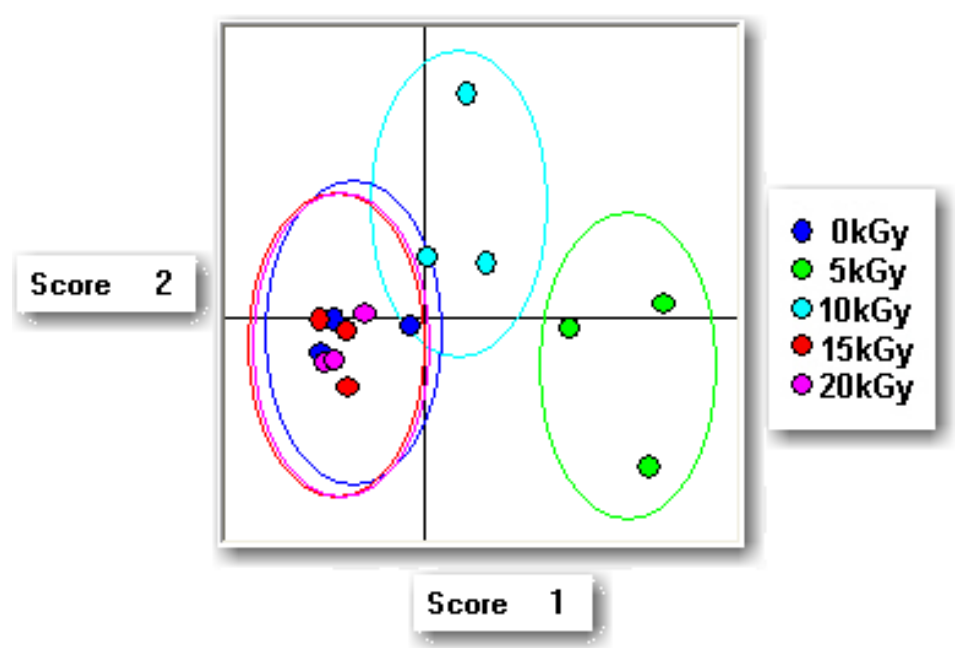

FIGURA 28 - Análise de componentes principais do chá preto irradiado com diferentes doses.

Apesar dos chás serem provenientes da mesma planta, cada tipo de chá possui sua característica própria, devido aos diferentes tratamentos que são submetidos. Por essa razão eles são produtos diferentes e devido a isso apresentaram comportamentos diferentes quando submetidos ao tratamento por radiação ionizante.

A análise de componentes principais mostrou que quanto maior a ação enzimática sofrido pela planta, por meio da polifenoloxidase, maior foi à interação da radiação com os compostos voláteis. Enquanto os chás brancos e verdes tiveram uma pequena diferença entre as amostras irradiadas com a amostra controle, o chá oolong e principalmente o chá preto apresentaram uma grande diferença entre as amostras irradiadas com 5 e 10kGy.

Muitos estudos relatam que os principais componentes que constituem o aroma de chás preto e oolong são: linalol, geraniol, óxido de linalol, feniletil álcool, $\alpha$-terpineol e fitol, ou seja, compostos alcoólicos. Esses COV estão presente nas folhas na forma de dissacarídeos glicosilados como $\beta$-primeverosídeo, $\beta$-acuminosídeo e $\beta$-vicianosídeo. 
Quando essas folhas são esmagadas e trituradas enzimas como a $\beta$-glucosidase e $\beta$ primeverosidase hidrolisam os açúcares glicosilados transformando nos compostos alcoólicos (Cho et al., 2007).

Esses compostos alcoólicos tiveram sua concentração aumentada, principalmente nas doses de 5 e 10kGy, não somente nos chás branco e verde, que não sofreram a ação de enzimas, mas também no chá oolong, que sofreu ação enzimática parcial e no preto, que já sofreu hidrólise, evidenciando que a radiação quebrou os açúcares glicosilados liberando os álcoois. Na maioria desses COV quando irradiados com doses de 15 e 20kGy, suas concentrações diminuíram, pois tanto os compostos glicosilados foram degradados, assim como parte dos alcoólicos.

Um composto que chama muita atenção é a cafeína, pois em todos os tipos de chás, a radiação interferiu diretamente na concentração de cafeína. No chá branco, a cafeína aumentou $6.389,26 \%$ entre a amostra controle e a irradiada com 20kGy, no chá verde esse composto só foi identificada a partir de $5 \mathrm{kGy}$ e conforme a dose aumentou sua concentração diminuiu, no chá preto, esse composto aumentou 3.353,88\% entre a amostra controle e 5kGy, porém diminuiu 2.521,28\% entre as doses de 5 e 20kGy, no chá oolong, a radiação variou aumentando e diminuindo a contração conforme a dose aumentava (FIG. 29).

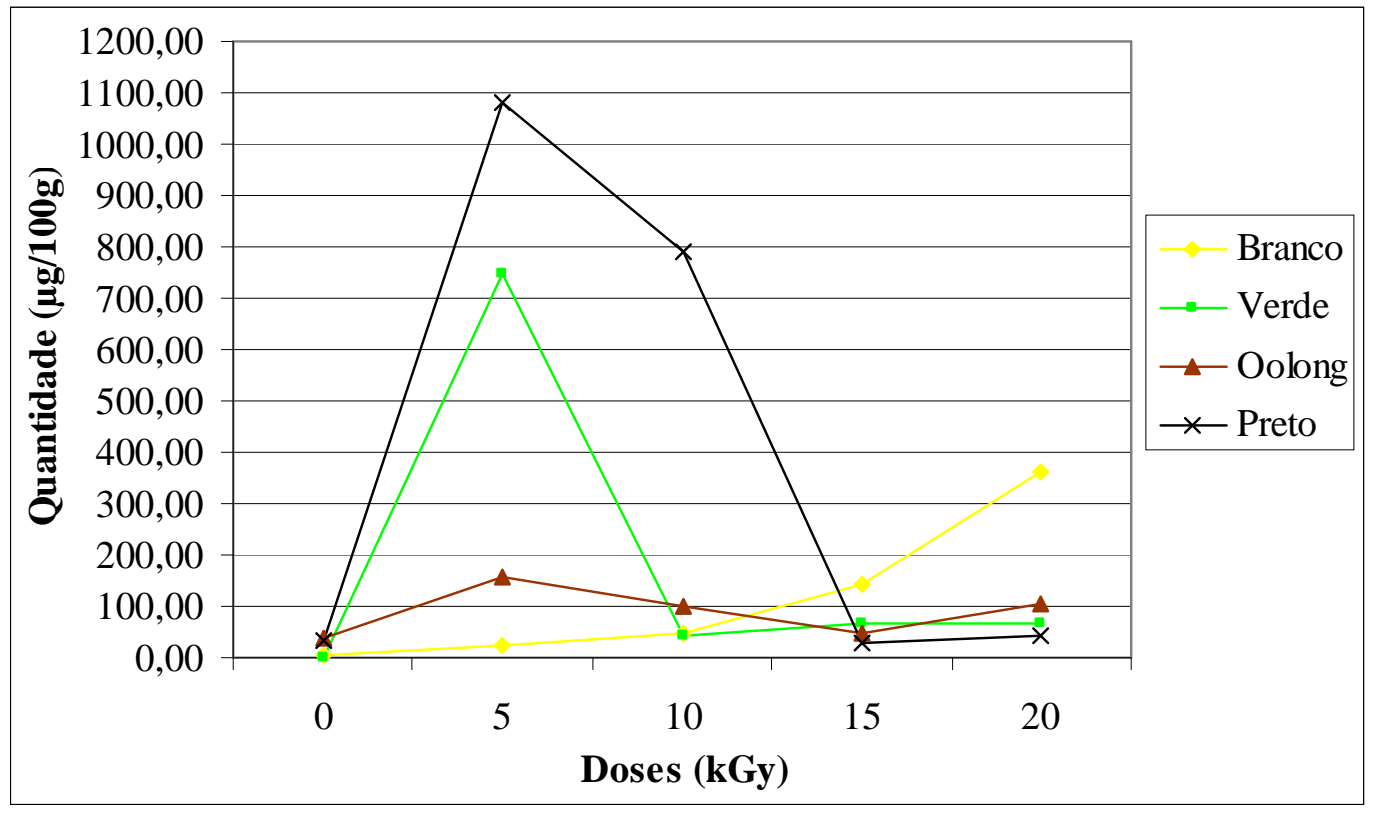

FIGURA 29 - Quantidade de cafeína, em $\mu \mathrm{g} / 100 \mathrm{~g}$ de chá, nos diferentes tipos de chá irradiados. 
Segundo De Maria e Moreira (2007), os efeitos da cafeína sobre o comportamento humano têm sido objeto de estudos há algumas décadas. Esses efeitos podem ser descritos como aumento da capacidade de alerta e redução da fadiga, com concomitante melhora no desempenho de atividades que requeiram maior vigilância (Castellanos e Rapoport, 2002; Smith, 2002).

James (2004) descreve que o efeito da ingestão de cafeína sobre o sistema cardiovascular ainda é motivo de grande controvérsia. Seu consumo regular parece elevar a pressão arterial de forma persistente e, desta forma, os chás da planta $C$. sinensis, principalmente irradiados não devem ser ingeridos por indivíduos com hipertensão, doença coronariana e arritmia cardíaca.

Em todos os chás, a radiação aumentou a formação principalmente de compostos com odores agradáveis, mas isso não significa que o consumidor irá aprovar o novo aroma formado, pois cada composto, tanto com característica agradável quando desagradável, têm seu papel na constituição do aroma. Um exemplo disso é o COV indole, que possui odor de naftalina, mas é descrito por muitos autores como constituinte natural do aroma dos chás da planta C. sinensis (Hattori et al., 2005; Owuor et al., 2008).

Para ter certeza, uma análise sensorial deverá ser feita para ver se a formação dos novos compostos voláteis irá interferir ou não na percepção do consumidor, entretanto, Furgeri et al. (2007) realizaram análise sensorial em erva mate (Ilexis paraguariensis) irradiado com doses de até 10kGy e demonstraram que não houve diferença entre as amostras irradiadas e não irradiadas. Salum et al. (2007) demonstraram que em sua análise sensorial que os participantes tiveram dificuldades em definir diferenças no odor entre a amostra controle e a amostra irradiada de canela e noz-moscada. 


\section{CONCLUSÃO}

- O chá verde foi o chá que mais sofreu interferência da radiação no número de componentes voláteis, seguido pelo chá preto, oolong e branco respectivamente.

- A radiação ionizante formou mais compostos voláteis do que degradou os compostos encontrados naturalmente.

- Muitos dos COV encontrados naturalmente no chá verde, preto, oolong e branco foram estáveis a todas as doses de radiação.

- Para o chá branco e chá verde a radiação até $20 \mathrm{kGy}$ não alterou o perfil de compostos voláteis.

- Para o chá oolong houve diferença entre o perfil cromatográfico entre as doses 5 e $15 \mathrm{kGy}$, mas não há diferença entre as doses de radiação com o chá não irradiado.

- No chá preto houve diferença entre as amostras irradiadas com 5 e 10kGy e as outras inclusive com a amostra controle. 


\section{TRABALHOS FUTUROS}

- Uma análise sensorial deve ser feita para estudar se os novos voláteis formados e se os compostos encontrados naturalmente que foram degradados com o emprego da radiação irão interferir na percepção do consumidor.

- Estudar o efeito da radiação ionizante, na atividade antioxidante.

- Identificar e quantificar os principais antioxidantes antes e após o processamento por radiação. 


\section{ANEXO A}

Quantidade dos compostos orgânicos voláteis, em $\mu \mathrm{g} / 100 \mathrm{~g}$ de chá branco, e seus respectivos odores, identificados nas diferentes doses de radiação.

\begin{tabular}{|c|c|c|c|c|c|c|c|c|}
\hline \multirow{3}{*}{ \#CAS } & \multirow{3}{*}{ Composto } & \multicolumn{5}{|c|}{ Quantidade $(\mu \mathrm{g})$} & \multirow{3}{*}{ Odor } & \multirow{3}{*}{ Referência } \\
\hline & & \multicolumn{5}{|c|}{ Doses (kGy) } & & \\
\hline & & $\mathbf{0}$ & 5 & 10 & 15 & 20 & & \\
\hline $18829-56-6$ & (E)-2-Nonenal & 7,95 & 20,97 & 29,22 & 17,17 & 30,18 & Pepino, Gramínea & Ullrich e Grosch, 1987 \\
\hline $35953-53-8$ & (E)-2-Tetradeceno & & & & 6,93 & & - & - \\
\hline $7069-41-2$ & (E)-2-Tridecenal & & & & & 18,66 & - & - \\
\hline $4313-03-5$ & (E,E)-2,4-Heptadienal & 5,07 & 42,09 & 64,13 & 32,77 & 363,02 & Fritura & Ullrich e Grosch 1988 \\
\hline $38284-27-4$ & (E,E)-3,5-Octadien-2-ona & & 30,55 & 113,37 & 119,75 & 279,28 & Fruta, Cogumelo & Ullrich e Grosch 1988 \\
\hline $2497-25-8$ & (Z)-2-Decenal & 22,62 & 49,97 & 60,79 & 30,52 & 64,87 & Sebo & $\begin{array}{c}\text { Schnermann e } \\
\text { Schieberle, } 1997\end{array}$ \\
\hline $876-02-8$ & 1-(4-Hidroxi-3-metilfenil)etanona & & 10,15 & 6,52 & 5,33 & & - & - \\
\hline 20194-67-6 & $\begin{array}{l}\text { 1,3,7,7-Tetrametil-9-oxo-2- } \\
\text { oxabiciclo[4.4.0]dec-5-eno }\end{array}$ & & & & & 8,21 & - & - \\
\hline $589-90-2$ & 1,4-dimetil Ciclohexano & & & 24,85 & & & - & - \\
\hline $17851-53-5$ & 1-Butil 2-isobutil Ftalato & 44,21 & 62,36 & 29,38 & 13,47 & & - & - \\
\hline $2167-14-8$ & 1-etil-1H-Pyrrole-2-carboxaldeído & & & & & 9,43 & - & - \\
\hline $13360-61-7$ & 1-Pentadeceno & & & & 7,62 & & - & - \\
\hline $195409 *$ & $\begin{array}{l}\text { 2,4,5,5,8a-Pentametil- } 6,7,8,8 \mathrm{a}- \\
\text { tetrahidro-5H-chromeno }\end{array}$ & 2,93 & & & & & - & - \\
\hline $2363-88-4$ & 2,4-Decadienal & 106,33 & 168,42 & 228,84 & 150,59 & 212,28 & Fritura, Gordura & Ullrich e Grosch, 1987 \\
\hline $96-76-4$ & 2,4-di-tert-butil Fenol & 4,74 & 8,97 & 20,50 & 17,68 & 10,04 & - & - \\
\hline $1125-21-9$ & $\begin{array}{l}\text { 2,6,6-Trimetil-2-ciclohexeno-1,4- } \\
\text { diona }\end{array}$ & & & 25,36 & 33,69 & 37,73 & - & - \\
\hline
\end{tabular}


Continuação do ANEXO A

\begin{tabular}{|c|c|c|c|c|c|c|c|c|}
\hline \multirow{3}{*}{ \#CAS } & \multirow{3}{*}{ Composto } & \multicolumn{5}{|c|}{ Quantidade $(\mu \mathrm{g})$} & \multirow{3}{*}{ Odor } & \multirow{3}{*}{ Referência } \\
\hline & & \multicolumn{5}{|c|}{ Doses (kGy) } & & \\
\hline & & $\mathbf{0}$ & 5 & 10 & 15 & 20 & & \\
\hline $5337-72-4$ & 2,6-dimetil Ciclohexanol & & & & 11,74 & & - & - \\
\hline $505-57-7$ & 2-Hexenal & & & & & 20,29 & Gordura, Ranço & Engel et al., 2002 \\
\hline $2463-77-6$ & 2-Undecenal & 18,25 & & & & & Doce & Gasser e Grosch, 1990 \\
\hline $196015^{*}$ & $\begin{array}{l}\text { 3,3-dimetil-2-(3-metil-1,3- } \\
\text { butadienil) Ciclohexane-1-metanol }\end{array}$ & & & & 7,25 & 6,31 & - & - \\
\hline $57396-75-5$ & 3,4-dimetil 2,4,6-Octatrieno & & & 8,13 & 4,88 & 5,80 & - & - \\
\hline $1708-27-6$ & 3-metil-2,3-dihidrofurano & 2,66 & & & & & - & - \\
\hline $922-61-2$ & 3-metil-2-Penteno & & 8,13 & 13,73 & 5,62 & 8,11 & - & - \\
\hline $98910-85-1$ & 3-oxo-beta-ionona & & & & 4,76 & & - & - \\
\hline $195148^{*}$ & $\begin{array}{l}\text { 4-(2,6,6-Trimetilciclohexa-1,3- } \\
\text { dienil)pent-3-en-2-ol }\end{array}$ & 4,47 & & & & & - & - \\
\hline $196665^{*}$ & $\begin{array}{l}\text { 4-(5,5-dimetil-1-oxaspiro[2.5]oct-4- } \\
\text { il)-3-Buten-2-ona }\end{array}$ & & & & & 7,66 & - & - \\
\hline $27185-77-9$ & 4-Oxo-beta-ionona & & & 11,17 & 9,68 & 5,58 & - & - \\
\hline $7786-61-0$ & 4-Vinilguaiacol & & & & & 9,43 & Cravo, Curry (Caril) & Blank et al., 1989 \\
\hline $56621-35-3$ & $\begin{array}{l}\text { 5,5-Dimetil-3-oxo-1-ciclohexeno-1- } \\
\text { carboxaldeído }\end{array}$ & & 12,91 & 14,76 & 15,27 & & - & - \\
\hline $502-69-2$ & 6,10,14-trimetil-2-Pentadecanona & 33,59 & 105,36 & 481,07 & 186,39 & 17,95 & Gortura & Mau et al., 2003 \\
\hline $762-29-8$ & $\begin{array}{l}\text { 6,10,14-trimetil-5,9,13- } \\
\text { Pentadecatrien-2-ona }\end{array}$ & 13,62 & 16,89 & 21,88 & 7,36 & 9,91 & Flor, Éter & Mau et al., 2003 \\
\hline $1604-28-0$ & 6-Metil-3,5-Heptadiene-2-ona & & 105,07 & 183,00 & 132,65 & 404,86 & - & - \\
\hline
\end{tabular}


Continuação do ANEXO A

\begin{tabular}{|c|c|c|c|c|c|c|c|c|}
\hline \multirow{3}{*}{ \#CAS } & \multirow{3}{*}{ Composto } & \multicolumn{5}{|c|}{ Quantidade $(\mu \mathrm{g})$} & \multirow{3}{*}{ Odor } & \multirow{3}{*}{ Referência } \\
\hline & & \multicolumn{5}{|c|}{ Doses $(\mathrm{kGy})$} & & \\
\hline & & $\mathbf{0}$ & 5 & 10 & 15 & 20 & & \\
\hline $37079-64-4$ & 7,8-Epoxi-alpha-ionona & 5,76 & & & & & - & - \\
\hline $62338-55-0$ & $\begin{array}{l}\text { 9-(1-metiletilideno)-1,5- } \\
\text { cicloundecadieno }\end{array}$ & & & 24,01 & & & - & - \\
\hline $98-86-2$ & Acetofenona & & & & & 13,43 & Flor, Amêndoa & Guichard et al., 1995 \\
\hline $103-23-1$ & $\begin{array}{l}\text { Ácido bis(2-etilhexil) éster } \\
\text { Hexanedióico }\end{array}$ & 72,41 & 67,62 & 25,35 & 59,63 & 72,18 & $\cos$ & 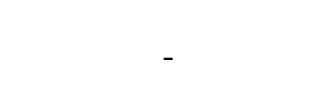 \\
\hline $142-62-1$ & Ácido Capróico & 24,70 & 128,00 & 153,15 & 90,12 & 105,85 & Doce & Adedeji et al., 1991 \\
\hline $123-79-5$ & Ácido dioctil ester Hexanedióico & & & 47,24 & & & - & - \\
\hline $57-11-4$ & Ácido Esteárico & 363,37 & & & & & - & - \\
\hline $628-97-7$ & Ácido etil ester Palmítico & & & & 1,72 & & Cera & Berger et al., 1989 \\
\hline $506-12-7$ & Ácido Margarínico & 8,07 & & & & & - & - \\
\hline $112-05-0$ & Ácido Nonanóico & 51,04 & 51,23 & 172,86 & 125,21 & 117,62 & Gramínea & Jirovetz et al., 2002 \\
\hline $124-07-2$ & Ácido Octanóico & 57,61 & 49,62 & 41,16 & 17,68 & & Doce, Queijo & Adedeji et al., 1991 \\
\hline $112-80-1$ & Ácido Oleico & 130,86 & & & & & Gordura & Berger et al., 1989 \\
\hline $57-10-3$ & Ácido Palmítico & 573,38 & & & & & - & - \\
\hline $112-39-0$ & Ácido Palmítico metilester & & & & 4,22 & & - & - \\
\hline $140-29-4$ & alfa-ciano-Toluene & & & 10,28 & 5,25 & 17,14 & - & - \\
\hline $98-55-5$ & alfa-Terpineol & 92,72 & 229,24 & 123,96 & 120,02 & 150,84 & Anis, Hortelã & Berger et al., 1989 \\
\hline $122-78-1$ & alfa-Tolualdeído & & 10,17 & 37,95 & 17,72 & 70,93 & Mel & $\begin{array}{c}\text { Schieberle e Grosch, } \\
1987\end{array}$ \\
\hline
\end{tabular}


Continuação do ANEXO A

\begin{tabular}{|c|c|c|c|c|c|c|c|c|}
\hline \multirow{3}{*}{ \#CAS } & \multirow{3}{*}{ Composto } & \multicolumn{5}{|c|}{ Quantidade $(\mu \mathrm{g})$} & \multirow{3}{*}{ Odor } & \multirow{3}{*}{ Referência } \\
\hline & & \multicolumn{5}{|c|}{ Doses (kGy) } & & \\
\hline & & $\mathbf{0}$ & 5 & 10 & 15 & 20 & & \\
\hline $100-51-6$ & alfa-Toluenol & 5,54 & 31,58 & 71,79 & 3,45 & 28,40 & Doce, Flor & Blank et al., 1989 \\
\hline $481-34-5$ & alfa-Cadinol & 6,88 & 9,55 & 30,00 & 23,49 & 27,18 & Erva, Madeira & Chung et al., 1993 \\
\hline $120-12-7$ & Antraceno & 3,13 & 3,26 & 3,59 & 3,74 & & - & - \\
\hline $100-52-7$ & Benzaldeído & & & 36,35 & 27,10 & 101,78 & Amêndoa, Caramelo & $\begin{array}{c}\text { Schieberle e Grosch, } \\
1987\end{array}$ \\
\hline $432-25-7$ & Beta Ciclocitral & 32,21 & 70,28 & 96,96 & 58,28 & 148,01 & Hortelã & Berger et al., 1989 \\
\hline $14901-07-6$ & Beta Ionona & 372,38 & 984,77 & 1146,59 & 787,04 & 1046,96 & Alga, Violeta, Framboesa & Berger et al., 1989 \\
\hline $119-36-8$ & Bétula & 10,90 & 31,96 & 54,08 & 36,55 & 109,98 & Hortelã-pimenta & Berger et al., 1989 \\
\hline $102572-89-4$ & Biciclo[13.1.0]hexadecan-2-ona & 4,24 & & & & & - & - \\
\hline $150320-52-8$ & $\begin{array}{l}\text { Biciclo[4.4.0]dec-1-eno, 2- } \\
\text { isopropil-5-metil-9-metileno }\end{array}$ & & & 9,10 & & & - & - \\
\hline 7299-89-0 & bis(2etilexil) Ftalato & & & & 2,58 & 2,33 & - & - \\
\hline $58-08-2$ & Cafeína & 5,68 & 22,02 & 47,70 & 142,26 & 362,91 & - & - \\
\hline $17334-55-3$ & Calareno & & & & & 4,29 & - & - \\
\hline $77-53-2$ & Cedrol & 9,17 & 10,07 & 16,13 & 22,68 & 11,62 & - & - \\
\hline $104-55-2$ & Cinamaldeído & & & & 16,00 & & Canela, Tinta & Jordan et al., 2003 \\
\hline $106-25-2$ & cis-Geraniol & 35,22 & 56,77 & 68,67 & 36,73 & 68,60 & Doce & Chung et al., 1993 \\
\hline $23726-93-4$ & Damascenona & 9,97 & 18,89 & 10,52 & 16,99 & 19,08 & Maçã, Rosa, Mel & Guth e Grosch, 1991 \\
\hline 84-74-2 & Dibutil Ftalato & & & & & 6,62 & - & - \\
\hline $17092-92-1$ & dihidro-Actinidiolida & 217,97 & 428,53 & 596,09 & 534,78 & 641,33 & - & - \\
\hline 629-97-0 & Docosano & & & & & 8,59 & Alcano & “flavor"net, 2009 \\
\hline
\end{tabular}


Continuação do ANEXO A

\begin{tabular}{|c|c|c|c|c|c|c|c|c|}
\hline \multirow{3}{*}{ \#CAS } & \multirow{3}{*}{ Composto } & \multicolumn{5}{|c|}{ Quantidade $(\mu \mathrm{g})$} & \multirow{3}{*}{ Odor } & \multirow{3}{*}{ Referência } \\
\hline & & \multicolumn{5}{|c|}{ Doses (kGy) } & & \\
\hline & & $\mathbf{0}$ & 5 & 10 & 15 & 20 & & \\
\hline $112-95-8$ & Eicosano & 5,08 & 7,85 & 10,26 & 11,37 & & Alcano & "flavor"net, 2009 \\
\hline $159366^{*}$ & Epóxido Isoaromadendreno & & & & & 11,04 & - & - \\
\hline $432-68-8$ & Equinenona & & & & 6,62 & & - & - \\
\hline $10031-82-0$ & Etoxibenzaldeído & 9,40 & 12,36 & 36,96 & 22,30 & 10,78 & - & - \\
\hline $97-53-0$ & Eugenol & 8,17 & 8,22 & 10,96 & 16,73 & 7,32 & Cravo, Mel & Blank et al., 1989 \\
\hline $502-67-0$ & Farnesal & & & 8,41 & 12,08 & 3,98 & - & - \\
\hline $85-01-8$ & Fenantreno & & & & 8,70 & 6,12 & - & - \\
\hline $60-12-8$ & Feniletil álcool & 23,93 & 59,62 & 96,09 & 63,62 & 131,70 & Mel, Pimenta, Rosa & Blank et al., 1989 \\
\hline $150-86-7$ & Fitol & 52,00 & 7,16 & 38,14 & 84,21 & 94,37 & Flor & Chung et al., 1993 \\
\hline $141-27-5$ & Geranial & 18,51 & 79,83 & 96,76 & 59,56 & 151,37 & Limão, Hortelã & Schieberle e Grosch, 1988 \\
\hline $3796-70-1$ & Geranilacetona & 436,32 & 558,90 & 636,09 & 406,58 & 646,21 & Magnólia, Gramínea & Mau et al., 2003 \\
\hline $593-49-7$ & Heptacosano & & & & 1,84 & & - & - \\
\hline $629-78-7$ & Heptadecano & 2,70 & 3,12 & 3,70 & 4,15 & & Alcano & "flavor"net, 2009 \\
\hline $84-69-5$ & Isobutil Ftalato & 63,35 & 67,82 & 129,22 & 107,38 & 131,21 & - & - \\
\hline $487-12-7$ & Isoelemicina & & 14,51 & & & & - & - \\
\hline $505-32-8$ & Isofitol & 3,09 & 3,21 & 2,76 & 2,43 & 2,33 & - & - \\
\hline $488-10-8$ & Jasmona & 7,32 & 9,77 & 22,25 & 21,13 & 18,86 & - & - \\
\hline $28580-43-0$ & Ledane & & & & 5,01 & & - & - \\
\hline $138-86-3$ & Limoneno & & & & 4,05 & & Limão, Laranja & Schieberle e Grosch, 1988 \\
\hline $78-70-6$ & Linalol & 174,97 & 294,14 & 389,28 & 210,22 & 485,15 & Flor, Lavanda & Schieberle e Grosch, 1988 \\
\hline $5129-60-2$ & metil 14-metil Pentadecanoato & 4,82 & 5,23 & 6,89 & 1,55 & 3,14 & - & - \\
\hline
\end{tabular}


Continuação do ANEXO A

\begin{tabular}{|c|c|c|c|c|c|c|c|c|}
\hline \multirow{3}{*}{ \#CAS } & \multirow{3}{*}{ Composto } & \multicolumn{5}{|c|}{ Quantidade $(\mu \mathrm{g})$} & \multirow{3}{*}{ Odor } & \multirow{3}{*}{ Referência } \\
\hline & & \multicolumn{5}{|c|}{ Doses (kGy) } & & \\
\hline & & $\mathbf{0}$ & 5 & 10 & 15 & 20 & & \\
\hline $1072-83-9$ & metil pirrol-2-il cetona & & 7,62 & & & & Noz, Nogueira, Pão & Yong et al., 1989 \\
\hline $7212-44-4$ & Nerolidol & 70,15 & 98,54 & 111,18 & 78,87 & 86,74 & Madeira, Flor & Chung et al., 1993 \\
\hline $104-61-0$ & Nonalactona & 8,74 & 25,69 & 48,70 & 32,57 & 59,51 & Coco, Pêsseco & Miranda-Lopez et al., 1992 \\
\hline $1139-30-6$ & Óxido beta-Cariofilleno & & 12,61 & 16,34 & 19,42 & & Erva, Doce, Pimenta & Chung et al., 1993 \\
\hline $70-70-2$ & Paroxipropiona & & & 18,12 & 15,42 & 13,59 & - & - \\
\hline $629-99-2$ & Pentacosano & & & & 1,95 & 2,98 & - & - \\
\hline $141-10-6$ & Pseudoionona & 56,37 & 59,71 & 75,73 & 66,30 & 79,67 & - & - \\
\hline $116-26-7$ & Safranal & 22,56 & 45,45 & 25,66 & 34,17 & 73,24 & Erva, Doce & Jorgensen et al., 2000 \\
\hline $6750-60-3$ & Spatulenol & & & & 8,58 & & Erva, Fruta & Jirovetz et al., 2002 \\
\hline $7683-64-9$ & Squaleno & 4,42 & 5,30 & 6,10 & 6,49 & 9,09 & - & - \\
\hline $5937-11-1$ & tau-Cadinol & 3,04 & 4,96 & 5,60 & 6,30 & 6,40 & - & - \\
\hline $21789-56-0$ & $\begin{array}{l}\text { trans-1,2,3,4,4a,5,8,8a-octahidro-4a- } \\
\text { metil Naftaleno }\end{array}$ & & & & 5,96 & & - & - \\
\hline $106-24-1$ & trans-Geraniol & 115,45 & 120,70 & 258,40 & 89,93 & 60,60 & Rosa, Gerânio & Berger et al., 1989 \\
\hline $131711^{*}$ & trans-Z-alfa-Bisaboleno epóxido & & & 10,37 & & & - & - \\
\hline
\end{tabular}

* Compostos que não possuem o número de identificação CAS (Chemical Abstracts Service) e, portanto foi utilizado o número de identificação da biblioteca NIST. 


\section{ANEXO B}

Quantidade dos compostos orgânicos voláteis, em $\mu \mathrm{g} / 100 \mathrm{~g}$ de chá verde, e seus respectivos odores, identificados nas diferentes doses de radiação.

\begin{tabular}{|c|c|c|c|c|c|c|c|c|}
\hline \multirow{3}{*}{ \#CAS } & \multirow{3}{*}{ Composto } & \multicolumn{5}{|c|}{ Quantidade $(\mu g)$} & \multirow{3}{*}{ Odor } & \multirow{3}{*}{ Referência } \\
\hline & & \multicolumn{5}{|c|}{ Doses (kGy) } & & \\
\hline & & $\mathbf{0}$ & 5 & 10 & 15 & 20 & & \\
\hline $489-39-4$ & (+)Aromadendreno & & & 3,94 & & & Madeira & Chung et al., 1993 \\
\hline $18829-56-6$ & (E)-2-Nonenal & & & 23,11 & 62,26 & 33,52 & Pepino, Gramínea & $\begin{array}{l}\text { Ullrich e Grosch, } \\
\qquad 1987\end{array}$ \\
\hline $14850-23-8$ & (E)-4-Octeno & & & 3,80 & & & - & - \\
\hline $38284-27-4$ & (E,E)-3,5-Octadien-2-ona & 44,08 & 22,74 & 124,19 & 417,45 & 172,21 & Fruta, Cogumelo & Ullrich e Grosch 1988 \\
\hline $4313-03-5$ & $(\mathrm{E}, \mathrm{E})-2,4-H e p t a d i e n a l$ & 9,76 & 46,55 & 97,08 & 437,97 & 215,78 & Fritura & Ullrich e Grosch 1988 \\
\hline $62951-96-6$ & (Z)-2,6,10-trimetil-1,5,9-Undecatrieno & & & & & 8,14 & - & - \\
\hline $2497-25-8$ & (Z)-2-Decenal & 21,67 & 19,99 & 10,24 & 74,62 & 51,02 & Sebo & $\begin{array}{c}\text { Schnermann e } \\
\text { Schieberle, } 1997\end{array}$ \\
\hline $54789-45-6$ & 1-(2,3,6-trimetil) Fenil-3-buten-2-ona & & & 2,85 & & & - & - \\
\hline $14309-32-1$ & 1,2-Dimetil ciclopropeno & & 28,42 & 8,55 & & & - & - \\
\hline $197084 *$ & $\begin{array}{l}\text { 1,3,3-trimetil-2-(1-metilbut-1-en-3-on-1-il)-1- } \\
\text { Ciclohexene }\end{array}$ & 4,76 & & & & & - & - \\
\hline $621-23-8$ & 1,3,5-trimetil Benzeno & & 8,39 & & & & - & - \\
\hline $17851-53-5$ & 1-Butil 2-isobutil Ftalato & 51,20 & 15,21 & 13,44 & 9,74 & 13,66 & - & - \\
\hline $52954-47-9$ & 1-metil-cis-1,2-epoxiciclooctano & & & & 27,77 & & - & - \\
\hline $2944-49-2$ & 1-metoxi-2,3-dimetil-Benzeno & & & & & 4,84 & - & - \\
\hline $104-45-0$ & 1-metoxi-4-propil Benzeno & & 18,54 & & & & - & - \\
\hline $62199-51-3$ & 1-pentil-2-propilciclopentano & & & & 10,08 & & - & - \\
\hline $2437-56-1$ & 1-Trideceno & & & 3,25 & 8,37 & & - & - \\
\hline $20490-42-0$ & 2,3,6-trimetil Naftoquinona & & & 1,17 & 9,29 & & - & - \\
\hline $74421-35-5$ & 2,3,6-trimetil-1,6-Heptadieno & & & & & 12,78 & - & - \\
\hline
\end{tabular}


Continuação do ANEXO B

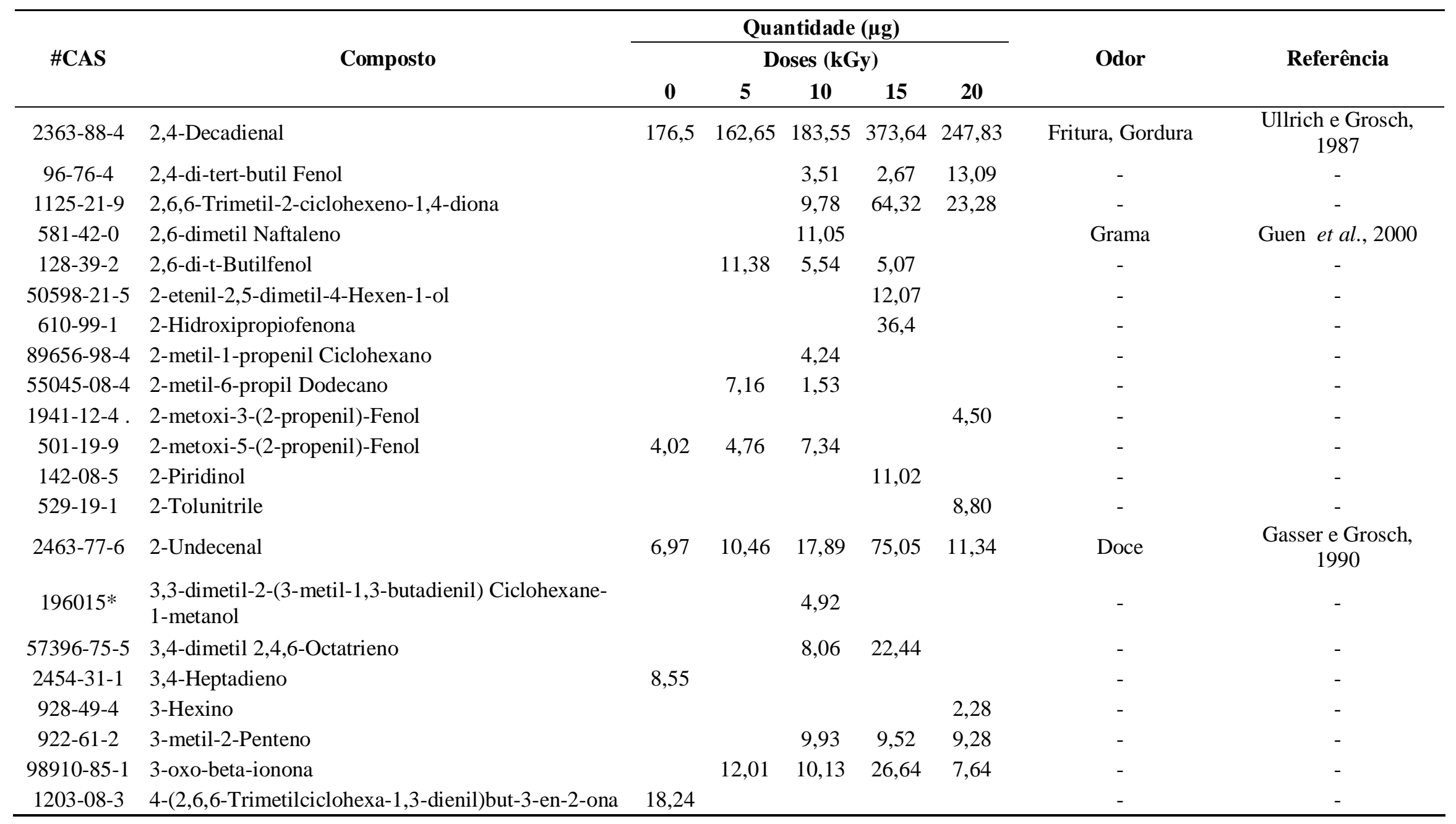


Continuação do ANEXO B

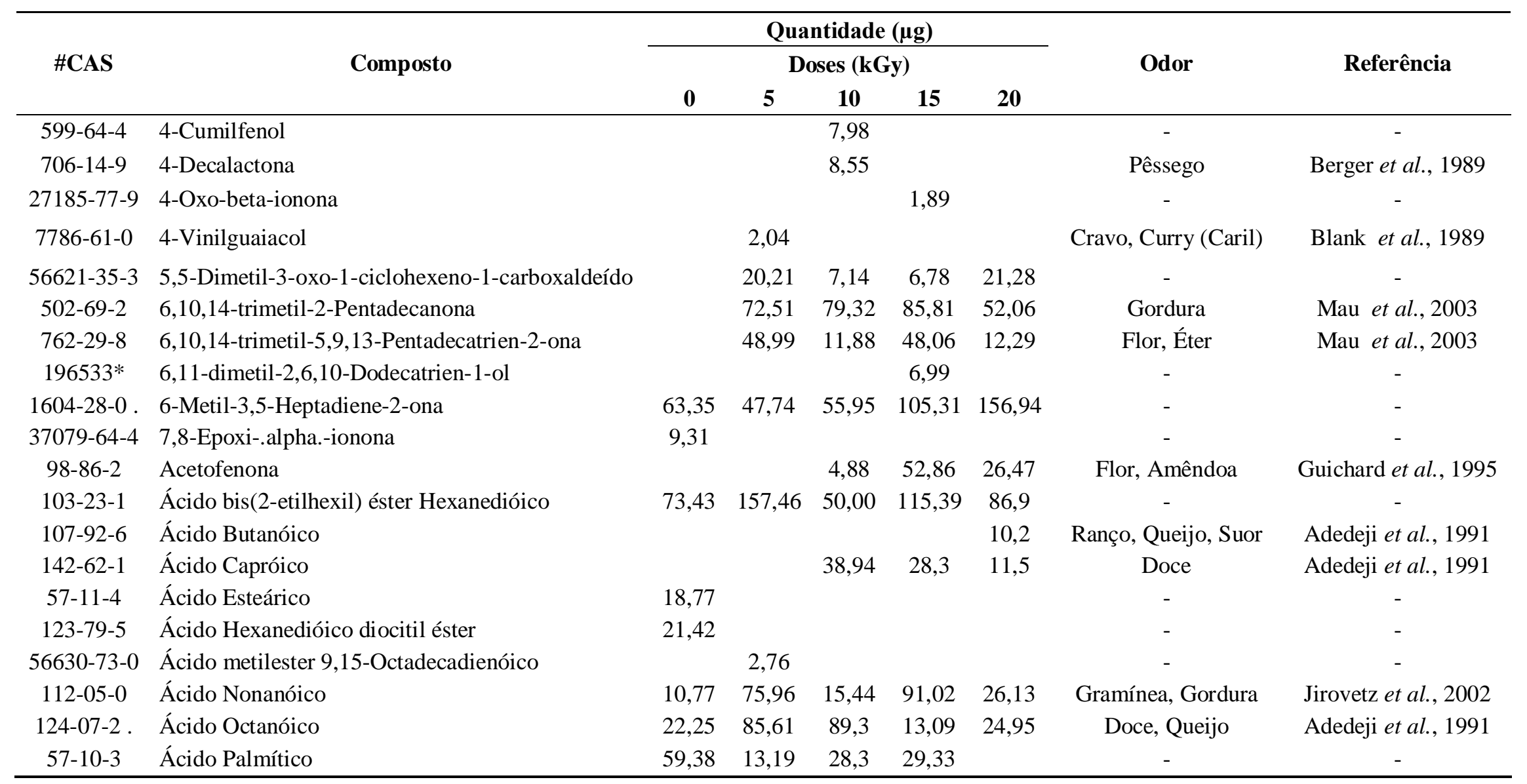


Continuação do ANEXO B

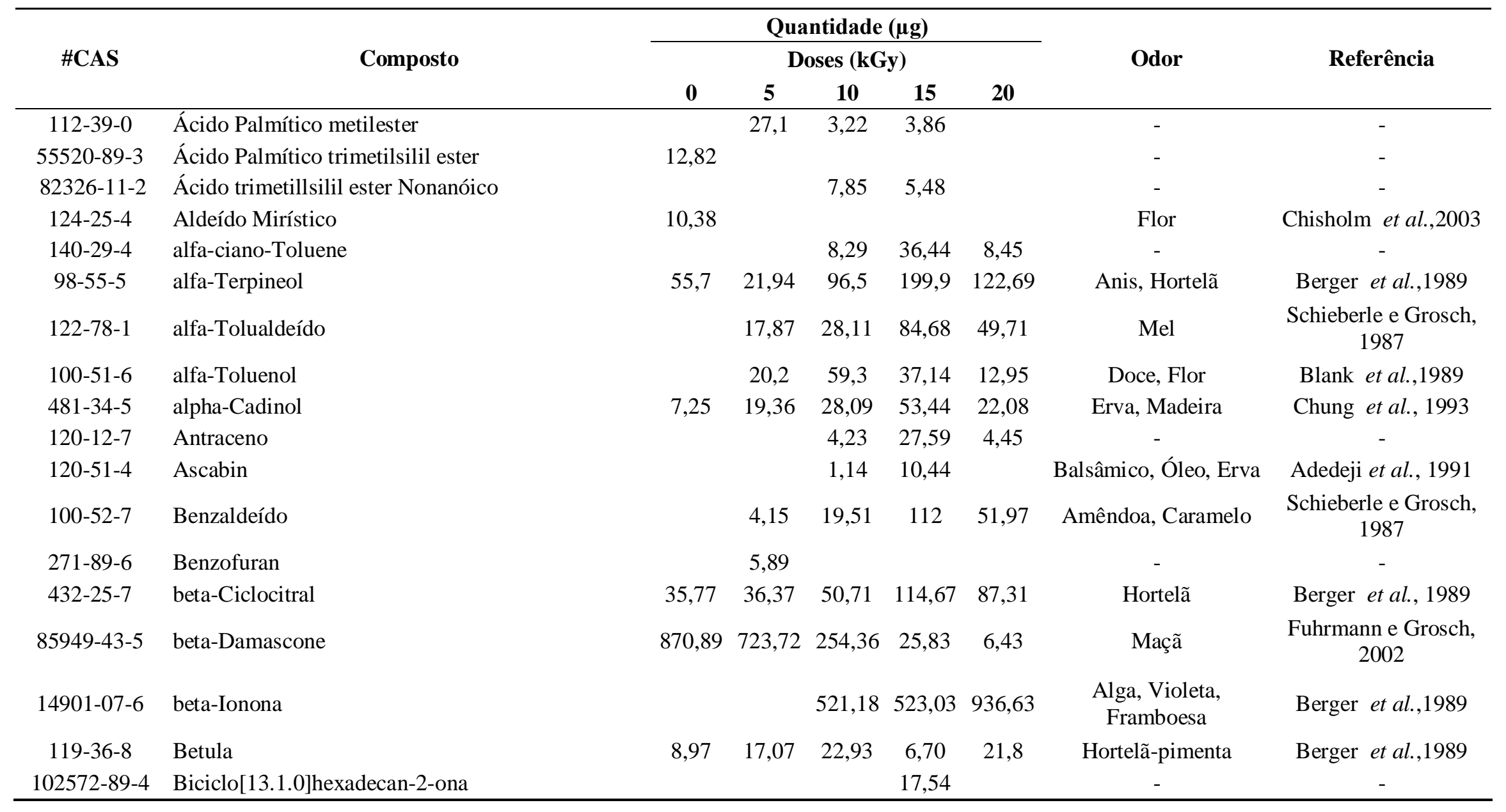


Continuação do ANEXO B

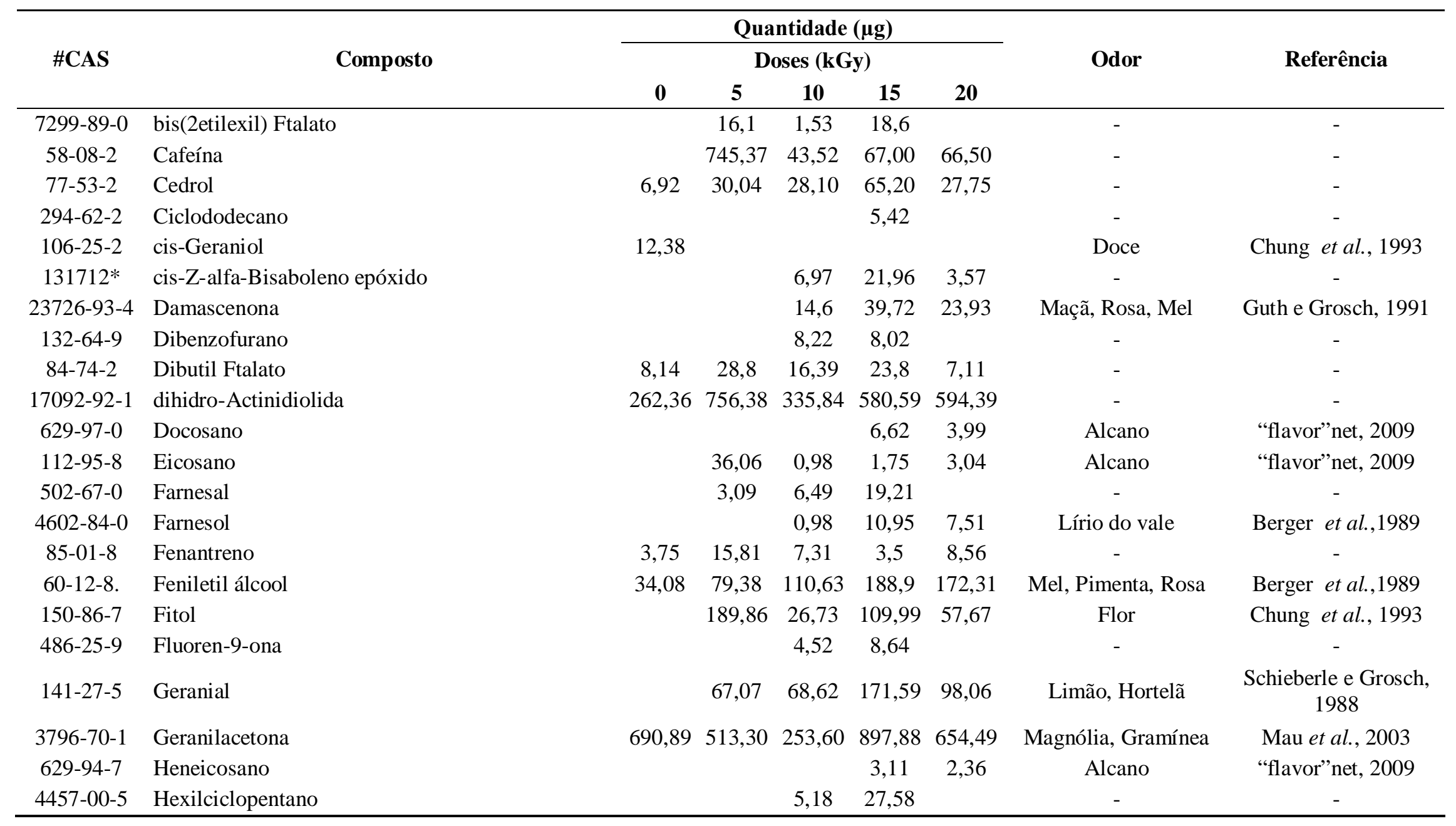


Continuação do ANEXO B

\begin{tabular}{|c|c|c|c|c|c|c|c|c|}
\hline \multirow[b]{2}{*}{ \#CAS } & \multirow[b]{2}{*}{ Composto } & \multicolumn{5}{|c|}{ Quantidade ( $\mu \mathrm{g})$} & \multirow[b]{2}{*}{ Odor } & \multirow[b]{2}{*}{ Referência } \\
\hline & & \multicolumn{5}{|c|}{ Doses (kGy) } & & \\
\hline $84-69-5$ & Isobutil Ftalato & 73,95 & 171,23 & 49,33 & 148,79 & 109,25 & - & - \\
\hline $475-20-7$ & Junipeno & & & 4,89 & & & - & - \\
\hline $78-70-6$ & Linalol & 95,69 & 40,31 & 109,01 & 345,35 & 194,7 & Flor, Lavanda & $\begin{array}{l}\text { Schieberle e Grosch, } \\
1988\end{array}$ \\
\hline $7212-44-4$ & Nerolidol & 73,42 & 86,79 & 62,70 & 142,31 & 83,97 & Madeira, Flor, Cera & Chung et al., 1993 \\
\hline $630-03-5$ & Nonacosano & & 5,20 & 8,50 & 11,10 & & - & - \\
\hline $638-66-4$ & Octadecanal & 18,00 & & & & & Óleo & Choi, 2003 \\
\hline $593-45-3$ & Octadecano & & 17,16 & 13,40 & 5,20 & & Alcano & “flavor”net, 2009 \\
\hline $156128^{*}$ & Óxido Aloaromadendreno (1) & & & & 1,22 & & - & - \\
\hline $1139-30-6$ & Óxido beta-Cariofileno & 8,37 & 12,78 & 2,06 & 14,56 & & Erva, Doce, Pimenta & Chung et al., 1993 \\
\hline $116-26-7$ & Safranal & 23,81 & 17,31 & 21,55 & 145,46 & 56,70 & Erva, Doce & Jorgensen et al., 2000 \\
\hline $6750-60-3$ & Spatulenol & & 7,37 & 10,81 & 36,75 & 6,53 & Erva, Fruta & Jirovetz et al., 2002 \\
\hline $7683-64-9$ & Squaleno & & 14,77 & 1,09 & 12,16 & 4,21 & - & - \\
\hline $5937-11-1$. & tau-Cadinol & & & 7,08 & 29,01 & 5,81 & - & - \\
\hline $21789-56-0$ & $\begin{array}{l}\text { trans-1,2,3,4,4a,5,8,8a-octahidro-4a-metil } \\
\text { Naftaleno }\end{array}$ & & & 2,19 & 33,82 & 3,42 & - & - \\
\hline
\end{tabular}


Continuação do ANEXO B

\begin{tabular}{|c|c|c|c|c|c|c|c|c|}
\hline \multirow{3}{*}{ \#CAS } & \multirow{3}{*}{ Composto } & \multicolumn{5}{|c|}{ Quantidade $(\mu \mathrm{g})$} & \multirow{3}{*}{ Odor } & \multirow{3}{*}{ Referência } \\
\hline & & \multicolumn{5}{|c|}{ Doses (kGy) } & & \\
\hline & & $\mathbf{0}$ & 5 & 10 & 15 & 20 & & \\
\hline $3913-81-3$ & trans-2-Decenal & & & & & 4,06 & Sebo & $\begin{array}{c}\text { Gasser e Grosch, } \\
1990\end{array}$ \\
\hline $106-24-1$ & trans-Geraniol & 150,90 & 31,59 & 123,65 & 192,82 & 20,51 & Rosa, Gerânio & Berger et al., 1989 \\
\hline $131711^{*}$ & trans-Z-alfa-Bisaboleno epóxido & & & 6,58 & & & - & - \\
\hline $638-67-5$ & Tricosano & & & & 1,46 & & Alcano & “flavor"net, 2009 \\
\hline
\end{tabular}

* Compostos que não possuem o número de identificação CAS (Chemical Abstracts Service) e, portanto foi utilizado o número de identificação da biblioteca NIST. 


\section{ANEXO C}

Quantidade dos compostos orgânicos voláteis, em $\mu \mathrm{g} / 100 \mathrm{~g}$ de chá oolong, e seus respectivos odores, identificados nas diferentes doses de radiação.

\begin{tabular}{|c|c|c|c|c|c|c|c|c|}
\hline \multirow[b]{2}{*}{ \#CAS } & \multirow[b]{2}{*}{ Composto } & \multicolumn{5}{|c|}{ Quantidade $(\mu \mathrm{g})$} & \multirow[b]{2}{*}{ Odor } & \multirow[b]{2}{*}{ Referência } \\
\hline & & \multicolumn{5}{|c|}{ Doses (kGy) } & & \\
\hline $62413-60-9$ & $\begin{array}{l}\text { (2E)-2-Etilidene-1,7,7- } \\
\text { trimetilbiciclo[2.2.1]heptano }\end{array}$ & 9,62 & & & & & - & - \\
\hline $7498-66-0$ & (3-clorofenil)(4-clorofenil)-Metanona & & & 6,72 & & & - & - \\
\hline $25152-84-5$ & (E,E)-2,4-Decadienal & & & 37,44 & 69,04 & 160,21 & Fritura, gordura & Ullrich e Grosch, 1987 \\
\hline $4313-03-5$ & (E,E)-2,4-Heptadienal & 16,47 & 48,25 & 99,66 & & & Fritura & Ullrich e Grosch 1988 \\
\hline $490-78-8$ & 1-(2,5-dihidroxifenil)-Etanona & & & 18,71 & 12,98 & 8,73 & - & - \\
\hline $30364-38-6$ & 1,1,6-trimetil-1,2-dihidro-Naftaleno & 75,12 & 89,37 & 125,39 & 157,54 & & Licorice & Jorgensen et al., 2000 \\
\hline $26137-53-1$ & $\begin{array}{l}\text { 1,2,3-Trimetil-4-[(1E)-1- } \\
\text { propenil]naftaleno }\end{array}$ & 26,11 & & & & & - & 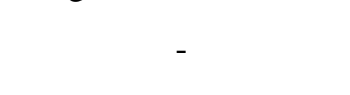 \\
\hline $17527-28-5$ & 1,2-bis(3-ciclohexenil)Etileno & & & & & 11,96 & - & - \\
\hline 159087-74-8 & 1,4-Dihidrotujopseno-(I1) & & & 40,34 & & & - & - \\
\hline $28289-54-5$ & 1-Metil-4-fenil-1,2,3,6-tetrahidropiridina & & & & 15,58 & & - & - \\
\hline $189429 *$ & $\begin{array}{l}\text { 2,3,3,4,7-pentametil-2,3-dihidro- } \\
\text { Benzofurano }\end{array}$ & & & & 15,85 & 14,16 & - & - \\
\hline $96-76-4$ & 2,4-di-tert-butilfenol & & & & & 13,07 & - & - \\
\hline $5910-87-2$ & 2,4-Nonadien-1-al & & & 20,06 & & & Gordura, Cera, Gramínea & Ullrich e Grosch, 1987 \\
\hline $700-13-0$ & 2,5,5-trimetil-1,4-Benzenediol & & & & 9,91 & & - & - \\
\hline
\end{tabular}




\section{Continuação do ANEXO C}

\begin{tabular}{|c|c|c|c|c|c|c|c|c|}
\hline \multirow{3}{*}{ \#CAS } & \multirow{3}{*}{ Composto } & \multicolumn{5}{|c|}{ Quantidade $(\mu \mathrm{g})$} & \multirow{3}{*}{ Odor } & \multirow{3}{*}{ Referência } \\
\hline & & \multicolumn{5}{|c|}{ Doses (kGy) } & & \\
\hline & & $\mathbf{0}$ & 5 & 10 & 15 & 20 & & \\
\hline $13360-65-1$ & 2,5-dimetil-3-ethilpirazina & 8,95 & 18,27 & 21,27 & 3,01 & 34,36 & Batata & Schieberle e Grosch, 1987 \\
\hline $5875-45-6$ & 2,5-di-tert-butilfenol & 40,71 & 120,28 & 98,56 & 52,17 & 13,65 & - & - \\
\hline $1125-21-9$ & 2,6,6-trimetil-2-Ciclohexeno-1,4-diona & 11,87 & 47,85 & 52,40 & 8,64 & & - & - \\
\hline $5337-72-4$ & 2,6-dimetil-Ciclohexanol & & & & & 43,89 & - & - \\
\hline $128-39-2$ & 2,6-Di-tert-butilfenol & & & & 14,20 & & - & - \\
\hline $620-17-7$ & 2-etil-Fenol & & 8,54 & & & & - & - \\
\hline $140-26-1$ & 2-Feniletil 3-metilbutirato & & & 12,65 & & & - & - \\
\hline $103-48-0$ & 2-Feniletilisobutirato & & & & 7,61 & & - & - \\
\hline $672-13-9$ & 2-Hidroxi-5-metoxibenzaldeído & & & & 8,39 & & - & - \\
\hline $131876^{*}$ & 2-metil-3-fenil-Propanal & & & & 3,81 & & - & - \\
\hline $501-19-9$ & 2-metoxi-3-(2-propenil)-Fenol & 10,52 & 9,96 & 15,33 & 15,50 & 33,35 & - & - \\
\hline $25773-40-4$ & 2-metoxi-3-isopropilpirazina & & & & & 11,88 & Ervilha, Terra & Blank e Grosch , 1991 \\
\hline 19784-98-6 & 2-metoxi-5-[(1E)-1-propenil]Fenol & & & & & 13,10 & - & - \\
\hline $614-68-6$ & 2-Tolil isocianato & 41,38 & 88,51 & 80,16 & 158,86 & 199,12 & - & - \\
\hline $529-19-1$ & 2-Tolunitrila & 66,31 & 69,45 & 22,51 & & & - & - \\
\hline $37740-08-2$ & $\begin{array}{l}3,3,4,7-\text { Tetrametil-2-benzofuran-1(3H)- } \\
\text { ona }\end{array}$ & & & & 19,91 & & - & - \\
\hline $54789-22-9$ & 3,3,5,6-tetrametil-1-indanona & 61,81 & 72,53 & 50,79 & 47,04 & 21,73 & - & - \\
\hline $126605 *$ & 3,4-dihidro-4,5,7-trimetil-Coumarina & 18,35 & & & & & - & - \\
\hline $1138-52-9$ & 3,5-Di-tert-butilfenol & & & 7,39 & 12,13 & & - & - \\
\hline $39515-51-0$ & 3-Fenoxibenzaldeído & & & & 6,20 & & - & - \\
\hline 83-34-1 & 3-metil-Indole & 28,97 & 35,89 & 47,28 & 31,20 & 20,59 & Naftalina & Widder et al., 1991 \\
\hline $1203-08-3$ & $\begin{array}{l}\text { 4-(2,6,6-Trimetilciclohexa-1,3- } \\
\text { dienil)but-3-en-2-ona }\end{array}$ & 28,65 & 19,58 & 26,35 & 12,60 & 28,02 & - & - \\
\hline
\end{tabular}


Continuação do ANEXO C

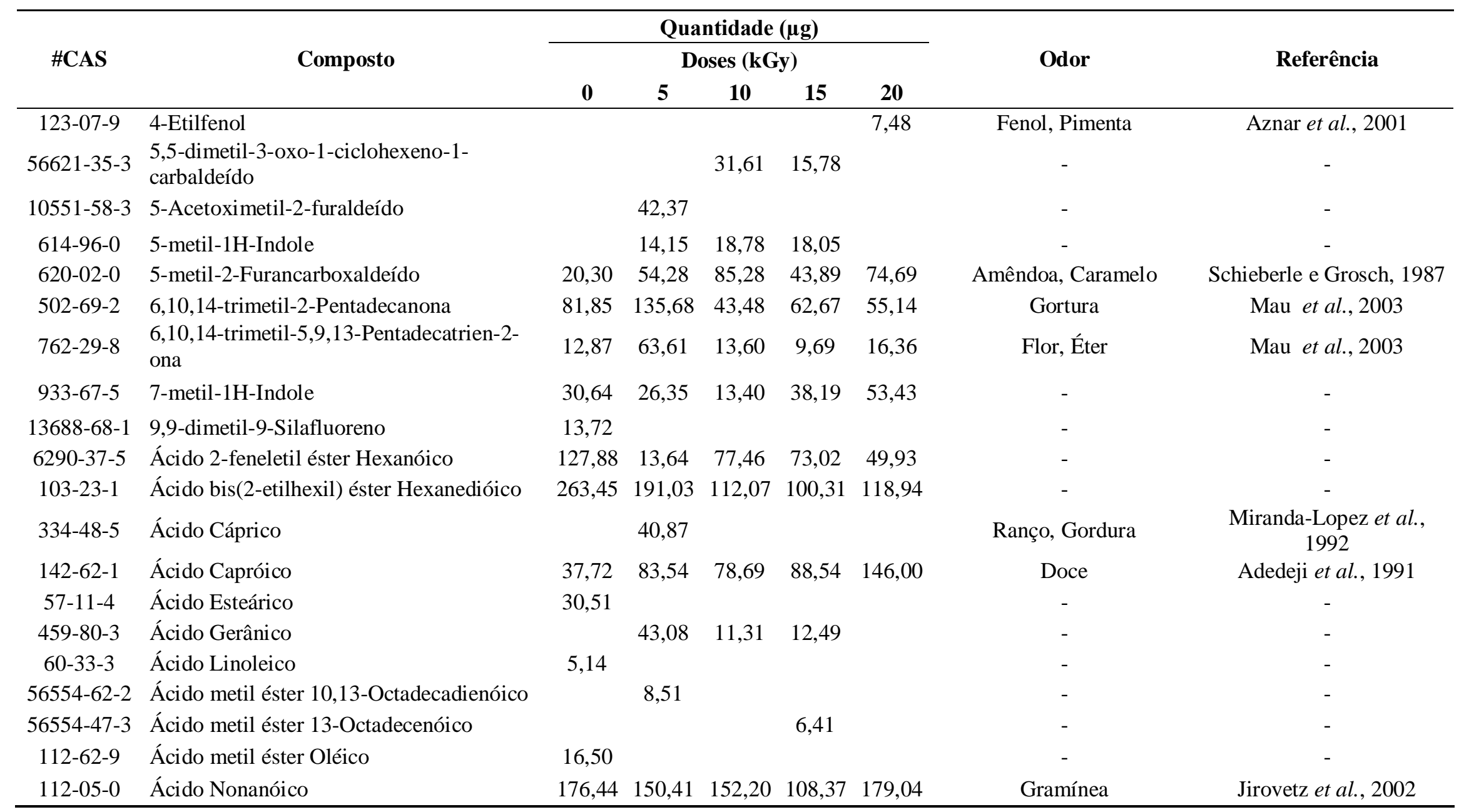


Continuação do ANEXO C

\begin{tabular}{|c|c|c|c|c|c|c|c|c|}
\hline \multirow{3}{*}{ \#CAS } & \multirow{3}{*}{ Composto } & \multicolumn{5}{|c|}{ Quantidade $(\mu \mathrm{g})$} & \multirow{3}{*}{ Odor } & \multirow{3}{*}{ Referência } \\
\hline & & \multicolumn{5}{|c|}{ Doses (kGy) } & & \\
\hline & & $\mathbf{0}$ & 5 & 10 & 15 & 20 & & \\
\hline $124-07-2$ & Ácido Octanóico & 273,09 & 37,19 & 43,16 & 22,73 & 25,20 & Doce, Queijo & Adedeji et al., 1991 \\
\hline $112-80-1$ & Ácido Oléico & 15,92 & & & & & Gordura & Berger et al., 1989 \\
\hline $57-10-3$ & Ácido Palmítico & 70,25 & 52,30 & & & & - & - \\
\hline $112-39-0$ & Ácido Palmítico metilester & 59,44 & 21,39 & 9,00 & 4,84 & 7,78 & - & - \\
\hline $112-79-8$ & Ácido trans-Oleico & 10,36 & & & & & - & - \\
\hline $2416-20-8$ & Ácido Z-11-Hexadecenóico & & 25,40 & & & & - & - \\
\hline $536-50-5$ & alfa,4-dimetil-Benzenemetanol & & & 30,19 & & & - & - \\
\hline $140-29-4$ & alfa-ciano-Toluene & 132,40 & 59,88 & 300,15 & 258,16 & 215,30 & - & - \\
\hline $120-51-4$ & Ascabin & & & 4,67 & & & Balsâmico, Óleo, Erva & Adedeji et al., 1991 \\
\hline $100-52-7$ & Benzaldeído & & & 8,04 & & & Amêndoa, Caramelo & Schieberle e Grosch, 1987 \\
\hline $432-25-7$ & beta-Ciclocitral & 23,87 & 36,87 & 55,28 & 47,69 & & Hortelã & Berger et al., 1989 \\
\hline 713-95-1 & beta-Dodecalactona & 205,17 & & & & & Fruta, Doce & Moio et al., 1994 \\
\hline $14901-07-6$ & beta-Ionona & 480,48 & 533,21 & 808,56 & 754,95 & 746,02 & Alga, Violeta, Framboesa & Berger et al., 1989 \\
\hline $119-36-8$ & Bétula & 151,91 & 112,85 & 335,44 & 386,30 & 401,05 & Hortelã-pimenta & Berger et al., 1989 \\
\hline $102572-89-4$ & Biciclo[13.1.0]hexadecan-2-ona & & 10,53 & & & & - & - \\
\hline 7299-89-0 & bis(2etilexil) Ftalato & 5,89 & 24,13 & 12,89 & 5,68 & & - & - \\
\hline $90-98-2$ & bis(4-clorofenil)-Metanona & & & 7,66 & 5,15 & 6,59 & - & - \\
\hline $58-08-2$ & Cafeína & 36,05 & 154,99 & 100,34 & 49,59 & 103,61 & - & - \\
\hline $122-03-2$ & Cuminal & & & & & 8,84 & Ácido & Chung et al., 1993 \\
\hline 84-74-2 & Dibutil Ftalato & 48,09 & 72,26 & 39,40 & 43,09 & 32,63 & - & - \\
\hline $17092-92-1$ & dihidro-Actinidiolida & 183,87 & 581,88 & 609,31 & 329,65 & 530,72 & - & - \\
\hline $27554-26-3$ & Diisooctilftalato & & 9,10 & 6,21 & 5,59 & & - & - \\
\hline 95-93-2 & Durol & & & 16,80 & & & Ranço, Doce & Luning et al., 1994 \\
\hline
\end{tabular}


Continuação do ANEXO C

\begin{tabular}{|c|c|c|c|c|c|c|c|c|}
\hline \multirow{3}{*}{ \#CAS } & \multirow{3}{*}{ Composto } & \multicolumn{5}{|c|}{ Quantidade $(\mu \mathrm{g})$} & \multirow{3}{*}{ Odor } & \multirow{3}{*}{ Referência } \\
\hline & & \multicolumn{5}{|c|}{ Doses (kGy) } & & \\
\hline & & $\mathbf{0}$ & 5 & 10 & 15 & 20 & & \\
\hline $97-53-0$ & Eugenol & 240,32 & 12,21 & 29,08 & 10,69 & & Cravo, Mel & Blank et al., 1989 \\
\hline $103-48-0$ & Fenetil isobutirato & 134,91 & & & & & - & - \\
\hline $60-12-8$ & Feniletil álcool & 139,18 & 136,63 & 274,41 & 242,28 & 351,93 & Mel, Pimenta, Rosa & Blank et al., 1989 \\
\hline $6290-37-5$ & Feniletilcaproato & & & & 11,53 & 7,92 & - & - \\
\hline $150-86-7$ & Fitol & 31,43 & 68,59 & 8,46 & 13,65 & 8,91 & Flor & Chung et al., 1993 \\
\hline $141-27-5$ & Geranial & 17,09 & & & & & Limão, Hortelã & Schieberle e Grosch, 1988 \\
\hline $3796-70-1$ & Geranilacetona & 259,53 & 245,68 & 437,59 & 449,56 & 375,38 & Magnólia, Gramínea & Mau et al., 2003 \\
\hline $90-05-1$ & Guaiacol & & & & & 24,78 & Fumaça, Doce, Remédio & Ong et al., 1999 \\
\hline $593-49-7$ & Heptacosano & & 11,97 & & & & - & - \\
\hline $630-06-8$ & Hexatriacontano & & 15,02 & & & & - & - \\
\hline $120-72-9$ & Indole & 143,93 & 34,89 & 87,66 & 72,14 & 140,33 & Naftalina, Queimado & Gasser e Grosch, 1990 \\
\hline $274-40-8$ & Indolizino & 37,09 & 52,11 & 116,62 & & & - & - \\
\hline $84-69-5$ & Isobutil Ftalato & 220,95 & 116,54 & 157,86 & 134,78 & 96,89 & - & - \\
\hline $97-54-1$ & Isoeugenol & & & & 13,60 & & Flor & Nishimura, 1995 \\
\hline $505-32-8$ & Isofitol & 26,35 & 43,02 & 8,86 & 14,51 & 7,93 & - & - \\
\hline $529-01-1$ & Isopiperitenona & & & 18,35 & & & Hortelã & Jirovetz et al., 2002 \\
\hline $488-10-8$ & Jasmona & 101,50 & 136,82 & 200,65 & 173,22 & 190,18 & - & - \\
\hline $78-70-6$ & Linalol & & & & 20,55 & & Flor, Lavanda & Schieberle e Grosch, 1988 \\
\hline $38818-55-2$ & Megastigmatrienona & & & & & 47,09 & - & - \\
\hline $122-00-9$ & Melilotal & 17,83 & & & & & Amêndoa amarga & Schieberle e Grosch, 1988 \\
\hline $42536-97-0$ & $\begin{array}{l}\text { Metil (3-oxo-2-[(2Z)-2- } \\
\text { pentenil]cyclopentil)acetato }\end{array}$ & 17,90 & 30,52 & 29,32 & 23,35 & 29,87 & - & - \\
\hline
\end{tabular}


Continuação do ANEXO C

\begin{tabular}{|c|c|c|c|c|c|c|c|c|}
\hline \multirow{3}{*}{ \#CAS } & \multirow{3}{*}{ Composto } & \multicolumn{5}{|c|}{ Quantidade $(\mu \mathrm{g})$} & \multirow{3}{*}{ Odor } & \multirow{3}{*}{ Referência } \\
\hline & & \multicolumn{5}{|c|}{ Doses (kGy) } & & \\
\hline & & $\mathbf{0}$ & 5 & 10 & 15 & 20 & & \\
\hline $5129-60-2$ & metil 14-metilpentadecanoato & & 38,75 & 26,87 & 10,30 & & - & - \\
\hline $211137 *$ & $\begin{array}{l}\text { metil éster (3-Oxo-2-pent-2- } \\
\text { enylciclopentil)acético }\end{array}$ & 133,47 & 82,40 & 107,14 & 60,58 & 81,83 & - & - \\
\hline $7212-44-4$ & Nerolidol & 320,32 & 415,27 & 502,40 & 492,17 & 443,60 & Madeira, Flor & Chung et al., 1993 \\
\hline $24340-88-3$ & N'-etil-N,N-dimetil-p-Fenilenediamina & & & 8,76 & & & - & - \\
\hline $630-03-5$ & Nonacosano & & 20,15 & & & & - & - \\
\hline $502-99-8$ & Ocimeno & & & & 11,49 & & Fruta, Pano molhado & Jordan et al., 2003 \\
\hline $593-45-3$ & Octadecano & 11,93 & 6,61 & 5,21 & 4,29 & & Alcano & “flavor”net, 2009 \\
\hline $22567-36-8$ & óxido Bisabolol A & & 21,67 & & & & - & - \\
\hline $26184-88-3$ & óxido Bisabolol II & 99,02 & 87,84 & 167,73 & 75,71 & 134,60 & - & - \\
\hline $159367 *$ & óxido Ledeno II & & & & 9,56 & & - & - \\
\hline $70-70-2$ & Paroxipropiona & 9,40 & 14,96 & 21,95 & 39,44 & 44,02 & - & - \\
\hline $97-54-1$ & Propenilguaiacol & 42,42 & 71,74 & 119,75 & 119,23 & 118,39 & Flor & Nishimura, 1995 \\
\hline $93-55-0$ & Propiofenona & & & 21,95 & 57,90 & 40,27 & - & - \\
\hline $141-10-6$ & Pseudoionona & 141,07 & 11,59 & 119,75 & 36,25 & 57,88 & - & - \\
\hline $116-26-7$ & Safranal & & & & 11,02 & 13,37 & Erva, Doce & Jorgensen et al., 2000 \\
\hline $7683-64-9$ & Squaleno & & 9,52 & & & & - & - \\
\hline $3913-81-3$ & trans-2-Decenal & & & & 19,78 & & Sebo & Gasser e Grosch, 1990 \\
\hline $1120-21-4$ & Undecano & 4,31 & & & & & Alcano & “flavor”net, 2009 \\
\hline
\end{tabular}

* Compostos que não possuem o número de identificação CAS (Chemical Abstracts Service) e, portanto foi utilizado o número de identificação da biblioteca NIST. 


\section{ANEXO D}

Quantidade dos compostos orgânicos voláteis, em $\mu \mathrm{g} / 100 \mathrm{~g}$ de chá preto, e seus respectivos odores, identificados nas diferentes doses de radiação.

\begin{tabular}{|c|c|c|c|c|c|c|c|c|}
\hline \multirow{3}{*}{ \#CAS } & \multirow{3}{*}{ Composto } & \multicolumn{5}{|c|}{ Quantidade $(\mu g)$} & \multirow{3}{*}{ Odor } & \multirow{3}{*}{ Referência } \\
\hline & & \multicolumn{5}{|c|}{ Doses (kGy) } & & \\
\hline & & $\mathbf{0}$ & 5 & 10 & 15 & 20 & & \\
\hline $4668-61-5$ & $\begin{array}{l}\text { 3,4,4a,5,6,7-hexahidro-1,1,4a-trimetil-2(1H)- } \\
\text { Naftalenona }\end{array}$ & 1,12 & & & & & - & - \\
\hline $489-39-4$ & (+)-Aromadendreno & 1,17 & 7,05 & & & & Madeira & Chung et al., 1993 \\
\hline $3155-71-3$ & $\begin{array}{l}\text { (2E)-2-Metil-4-(2,6,6-trimetil-1-ciclohexen-1- } \\
\text { il)-2-butenal }\end{array}$ & & & & 5,34 & & - & - \\
\hline $14237-73-1$ & (2E)-3,7,11,15-Tetrametil-2-hexadeceno & & 14,39 & & & & - & - \\
\hline $4411-89-6$ & (2Z)-2-Fenil-2-butenal & 2,56 & 31,08 & 5,81 & 3,24 & 3,93 & - & - \\
\hline $62951-96-6$ & (5Z)-2,6,10-Trimetil-1,5,9-undecatrieno & & & & 2,54 & & - & - \\
\hline $55138-79-9$ & (E)-trimetil-1-propenil-Pirazina & 0,72 & & & & & - & - \\
\hline $25152-84-5$ & (E,E)-2,4-Decadienal & & & & & 9,59 & Fritura, gordura & Ullrich e Grosch, 1987 \\
\hline $4313-03-5$ & (E,E)-2,4-Heptadienal & & 26,07 & & & & Fritura & Ullrich e Grosch 1988 \\
\hline $506-44-5$ & (Z,Z,Z)-9,12,15-Octadecatrien-1-ol & 2,66 & 8,54 & & & & - & - \\
\hline $1072-83-9$ & 1-(1H-pirrol-2-il)- Etanona & & 14,36 & & & & Noz, Nogueira, Pão & Yong et al., 1989 \\
\hline $55764-16-4$ & $\begin{array}{l}\text { 1,2,3,4-tetrahidro-1-(2-dietilaminoetil)-1-(4- } \\
\text { tolil)-Naftaleno }\end{array}$ & & 13,14 & & & & - & - \\
\hline $875-79-6$ & 1,2-dimeti-Indole & & 12,80 & & & & - & - \\
\hline $1012-72-2$ & 1,4-di-tert-butilbenzeno & & & & & 2,15 & - & - \\
\hline $112929-06-3$ & 1,9-Tetradecadieno & 1,62 & 27,39 & & & & - & - \\
\hline $55103-68-9$ & $\begin{array}{l}\text { 10a-Metildecahidrobenzo[a]cicloocten-2(1H)- } \\
\text { ona }\end{array}$ & & & 202,38 & 10,11 & & - & - \\
\hline
\end{tabular}




\section{Continuação do ANEXO D}

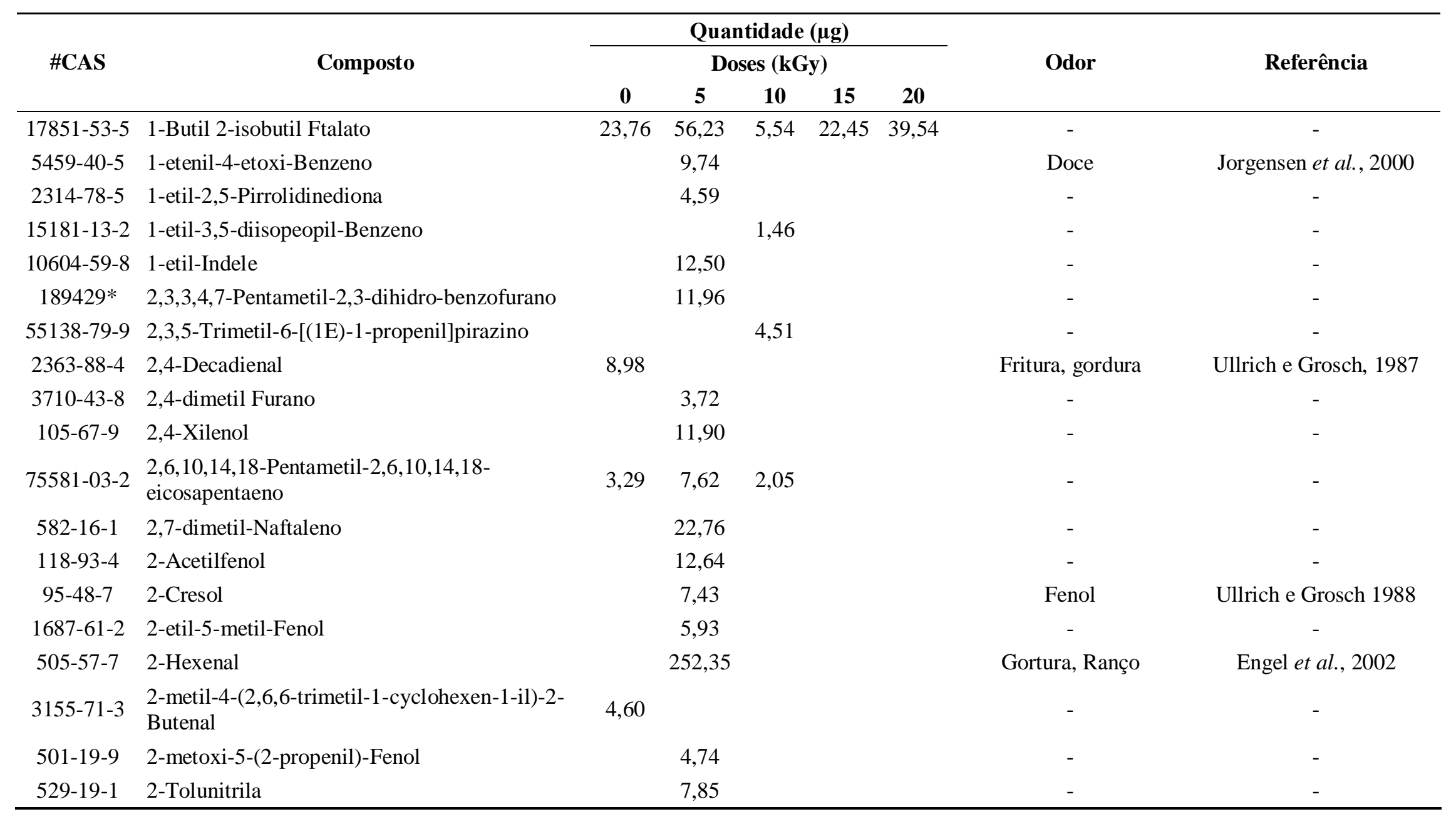


Continuação do ANEXO D

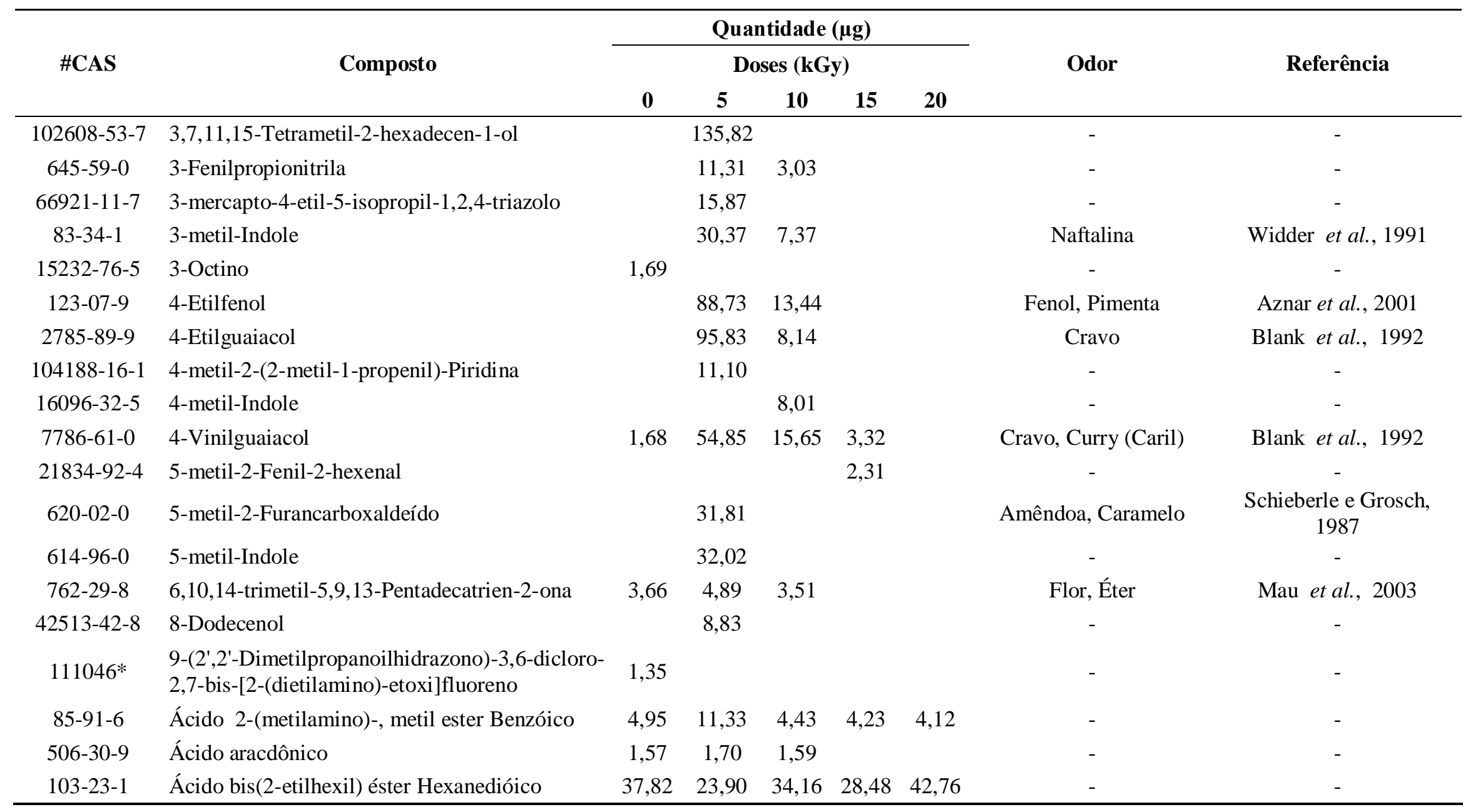




\section{Continuação do ANEXO D}

\begin{tabular}{|c|c|c|c|c|c|c|c|c|}
\hline \multirow{3}{*}{ \#CAS } & \multirow{3}{*}{ Composto } & \multicolumn{5}{|c|}{ Quantidade $(\mu \mathrm{g})$} & \multirow{3}{*}{ Odor } & \multirow{3}{*}{ Referência } \\
\hline & & \multicolumn{5}{|c|}{ Doses (kGy) } & & \\
\hline & & $\mathbf{0}$ & 5 & 10 & 15 & 20 & & \\
\hline $111-61-5$ & Ácido etil éster Esteárico & 8,36 & & & & & - & - \\
\hline $57274-46-1$ & Ácido etil éster, 15-metil-Heptadecanóico & & & 1,43 & & & - & - \\
\hline $459-80-3$ & Ácido Gerânico & & & & 3,55 & & - & - \\
\hline $301-00-8$ & Ácido metil éster Linolênico & & & 9,09 & & & - & - \\
\hline $629-79-8$ & Àcido nitrila Palmítico & & 22,54 & & & & - & - \\
\hline $57-10-3$ & Ácido Palmítico & & 239,32 & 4,61 & & & - & - \\
\hline $112-39-0$ & Ácido Palmítico metilester & 2,51 & 44,27 & 11,42 & & & - & - \\
\hline $140-29-4$ & alfa-ciano-Toluene & 7,10 & & & & & - & - \\
\hline $122-78-1$ & alfa-Tolualdeído & 2,30 & 160,26 & 16,06 & & & Mel & $\begin{array}{c}\text { Schieberle e Grosch, } \\
1987\end{array}$ \\
\hline $100-51-6$ & alfa-Toluenol & & 9,00 & & & & Doce, Flor & Blank et al., 1992 \\
\hline $100-52-7$ & Benzaldeído & & 16,75 & & & & Amêndoa, Caramelo & $\begin{array}{c}\text { Schieberle e Grosch, } \\
1987\end{array}$ \\
\hline $108-95-2$ & Benzenol & & 45,72 & 25,30 & & & Fenol & Rychlik et al., 1998 \\
\hline $432-25-7$ & beta-Ciclocitral & & 19,12 & & & & Hortelã & Berger et al., 1989 \\
\hline $14901-07-6$ & beta-Ionona & 81,81 & 127,28 & 63,81 & 79,00 & 95,20 & Alga, Violeta, Framboesa & Berger et al., 1989 \\
\hline
\end{tabular}




\section{Continuação do ANEXO D}

\begin{tabular}{|c|c|c|c|c|c|c|c|c|}
\hline \multirow{3}{*}{ \#CAS } & \multirow{3}{*}{ Composto } & \multicolumn{5}{|c|}{ Quantidade $(\mu \mathrm{g})$} & \multirow{3}{*}{ Odor } & \multirow{3}{*}{ Referência } \\
\hline & & \multicolumn{5}{|c|}{ Doses (kGy) } & & \\
\hline & & $\mathbf{0}$ & 5 & 10 & 15 & 20 & & \\
\hline $119-36-8$ & Betula & 1,60 & 152,64 & 10,49 & 2,81 & 5,09 & Hortelã-pimenta & Berger et al., 1989 \\
\hline 7299-89-0 & bis(2etilexil) Ftalato & 272,44 & 195,72 & 30,01 & 122,61 & 184,00 & - & - \\
\hline $58-08-2$ & Cafeína & 32,22 & 1080,62 & 792,70 & 26,79 & 42,86 & - & - \\
\hline $13567-54-9$ & Cedrano & 1,17 & & & & & - & - \\
\hline $64599 *$ & cis-2-Isopropilbiciclo[4.3.0]non-3en8ona & & & & & 3,29 & - & - \\
\hline $106-25-2$ & cis-Geraniol & 3,82 & 67,85 & 29,68 & 7,18 & & Doce & Chung et al., 1993 \\
\hline $91-64-5$ & Coumarina & & & 3,71 & & & Gramínea, Doce & Rychlik et al., 1998 \\
\hline 23726-93-4 & Damascenona & 3,45 & 52,89 & 78,90 & 21,30 & 2,87 & Maçã, Rosa, Mel & Guth e Grosch, 1991 \\
\hline 84-74-2 & Dibutil Ftalato & 19,67 & 21,98 & 12,88 & 15,05 & 24,11 & - & - \\
\hline 17092-92-1 & dihidro-Actinidiolida & 37,46 & 61,87 & 40,56 & 26,01 & 49,40 & - & - \\
\hline $27554-26-3$ & Diisooctilfthalato & & & 262,12 & & & - & - \\
\hline $112-95-8$ & Eicosano & 2,15 & 4,96 & 11,10 & 8,14 & 4,02 & Alcano & “flavor"net, 2009 \\
\hline 14049-11-7 & Epoxilinalol & & & 8,65 & 11,51 & 5,79 & Flor & Jorgensen et al., 2000 \\
\hline $502-61-4$ & Farneseno & & 6,36 & & & & Madeira, Doce & Chung et al., 1993 \\
\hline $60-12-8$ & Feniletil álcool & 3,72 & 6,98 & 8,83 & 7,90 & 3,38 & Mel, Pimenta, Rosa & Blank et al., 1992 \\
\hline $150-86-7$ & Fitol & 139,38 & 465,68 & 235,44 & 34,01 & 74,41 & Flor & Chung et al., 1993 \\
\hline $90-00-6$ & Florol & & 7,62 & 17,40 & & & - & - \\
\hline $3796-70-1$ & Geranilacetona & 15,70 & 24,28 & 14,67 & 15,53 & 17,72 & Magnólia, Gramínea & Mau et al., 2003 \\
\hline $630-04-6$ & Hentriacontano & & & 10,06 & & & - & - \\
\hline $87-85-4$ & Hexametilbenzeno & & 23,85 & & & & - & - \\
\hline $630-06-8$ & Hexatriacontano & & & 9,39 & 6,23 & 3,73 & - & - \\
\hline
\end{tabular}


Continuação do ANEXO D

\begin{tabular}{|c|c|c|c|c|c|c|c|c|}
\hline \multirow{3}{*}{ \#CAS } & \multirow{3}{*}{ Composto } & \multicolumn{5}{|c|}{ Quantidade $(\mu \mathrm{g})$} & \multirow{3}{*}{ Odor } & \multirow{3}{*}{ Referência } \\
\hline & & \multicolumn{5}{|c|}{ Doses (kGy) } & & \\
\hline & & $\mathbf{0}$ & 5 & 10 & 15 & 20 & & \\
\hline $120-72-9$ & Indole & & 131,90 & 38,68 & 3,56 & & Naftalinha, Queimado & Gasser e Grosch, 1990 \\
\hline $274-40-8$ & Indolizino & & & & & 2,91 & - & - \\
\hline $84-69-5$ & Isobutil Ftalato & 22,93 & 31,02 & 48,69 & 42,02 & 27,91 & - & - \\
\hline $97-54-1$ & Isoeugenol & & & 9,51 & & & Flore & Nishimura, 1995 \\
\hline $505-32-8$ & Isofitol & 13,07 & 31,04 & 12,43 & 6,37 & 1,91 & - & - \\
\hline $62338-56-1$ & Isopropilcicloundecano & & 2,82 & & & & - & - \\
\hline $78-70-6$ & Linalol & 18,69 & 150,90 & 24,41 & 25,60 & 28,13 & Flor, Lavanda & $\begin{array}{l}\text { Schieberle e Grosch, } \\
1988\end{array}$ \\
\hline $2571-52-0$ & Mesitonitrilo & & 18,89 & & & & - & - \\
\hline $42536-97-0$ & $\begin{array}{l}\text { Metil (3-oxo-2-[(2Z)-2-pentenil]ciclopentil) } \\
\text { acetato }\end{array}$ & & 5,01 & 1,83 & 2,35 & & - & - \\
\hline 499-03-6 & m-Menta-1,8-dieno & & & 2,75 & & & - & - \\
\hline $7212-44-4$ & Nerolidol & 25,93 & 36,41 & 18,80 & 16,03 & 23,21 & Madeira, Flor, Cera & Chung et al., 1993 \\
\hline $53832-62-5$ & N-Isobutinilanilina & & & 2,50 & & & - & - \\
\hline $630-03-5$ & Nonacosano & 8,17 & 103,96 & 27,48 & & & - & - \\
\hline $593-45-3$ & Octadecano & & 2,72 & & & & Alcano & “flavor"net, 2009 \\
\hline $90-05-1$ & o-Guaiacol & & 27,81 & 6,84 & & & Fumaça, Doce, Remédio & Rychlik et al., 1998 \\
\hline $123-69-3$ & Oxacicloheptadec-8-en-2-ona & & 12,76 & & & & - & - \\
\hline $5989-33-3$ & Óxido cis-Linalol & 2,92 & 40,20 & 16,19 & 6,57 & & Flor & Chung et al., 1993 \\
\hline $629-99-2$ & Pentacosaco & 4,04 & 6,67 & 5,06 & & & - & - \\
\hline $630-07-9$ & Pentatriacontano & 3,17 & 4,89 & 7,73 & & & - & - \\
\hline
\end{tabular}




\section{Continuação do ANEXO D}

\begin{tabular}{|c|c|c|c|c|c|c|c|c|}
\hline \multirow{3}{*}{ \#CAS } & \multirow{3}{*}{ Composto } & \multicolumn{5}{|c|}{ Quantidade $(\mu \mathrm{g})$} & \multirow{3}{*}{ Odor } & \multirow{3}{*}{ Referência } \\
\hline & & \multicolumn{5}{|c|}{ Doses (kGy) } & & \\
\hline & & $\mathbf{0}$ & 5 & 10 & 15 & 20 & & \\
\hline $150-76-5$ & p-Guaiacol & & 126,12 & 6,75 & & & - & - \\
\hline $2785-87-7$ & p-Propilguaiacol & & 6,43 & & & & Fenol & Lopez et al., 2003 \\
\hline $17598-02-6$ & Precoceno 1 & 4,15 & 3,94 & 3,57 & 3,10 & & - & - \\
\hline $97-54-1$ & Propenilguaiacol & & 36,95 & & & & Flor & Nishimura, 1995 \\
\hline $116-26-7$ & Safranal & & 12,05 & & & & Erva, Doce & Jorgensen et al., 2000 \\
\hline $91-10-1$ & Siringol & & 35,69 & 13,44 & & & Remédio, Fenol, Fumaça & Ferreira et al., 2001 \\
\hline $7683-64-9$ & Squaleno & & & 4,38 & 3,28 & 2,84 & - & - \\
\hline $22567-17-5$ & tau-Gurjunene & 12,10 & 7,86 & 3,48 & & & - & - \\
\hline $629-59-4$ & Tetradecano & & 17,27 & & & & Alcano & "flavor"net, 2009 \\
\hline $106-24-1$ & trans-Geraniol & 5,96 & 31,07 & 11,14 & 20,67 & 2,81 & Rosa, Gerânio & Berger et al., 1989 \\
\hline $629-50-5$ & Tridecano & & 3,97 & & & & Alcano & “flavor”net, 2009 \\
\hline $78-40-0$ & Trietilfosfato & 9,90 & 2,81 & 6,74 & 5,53 & 6,53 & - & - \\
\hline $4630-07-3$ & Valenceno & & & 1,76 & & & Gramínea, Óleo & Choi, 2003 \\
\hline $130983 *$ & Z-1,6-Tridecadieno & 3,57 & & & & & - & - \\
\hline
\end{tabular}

* Compostos que não possuem o número de identificação CAS (Chemical Abstracts Service) e, portanto foi utilizado o número de identificação da biblioteca NIST. 


\section{REFERÊNCIAS BIBLIOGRÁFICAS}

1 - ABOU-ARAB, A.A.K.; SOLIMAN KAWTHER, M. ; TANTAWY, M.E.E; ISMAIL BADEAA, R.; KHAYRIA, N. Quantity estimation of some contaminants in commonly used medicinal plants in the Egyptian market. Food Chem., v. 67, p. 357$363,1999$.

2 - ABU-IRMAILEH, B.E.; AFIFI, F.U. Herbal medicine in Jordan with special emphasis on commonly used herbs. J. Ethnopharmacol., v. 89, p. 193-197, 2003.

3 - ADEDEJI, J.; HARTMAN, T.G.; ROSEN, R.T.; HO, C.T. Free and glycosidically bound aroma compounds in hog plum (Spondias mombins L.). J. Agric. Food Chem., v. 39, p. 1494-1497, 1991.

4 - ALCARDE, A.R.; WALDER, J.M.M.; HORII, J. Fermetation od irradiated sugarcane must. Sci. Agric., v. 60, p. 677-681, 2003.

5 - AN, B.J. Chemical structure and isolated of angiotensin converting enzyme inhibitor from the Korean green tea. Life Resour. Ind., v. 2, p. 67-80, 1998.

6 - AN, B.J.; BAE, N.J.; CHOI, C. Inhibitory effect of flavan-3-olsisolated from Oolong tea on xanthine oxidase. Korean J. Food Scie. Techn., v. 28, p. 1084-1088, 1996.

7 - AN, B.J.; KWAK, J.H.; SON, J.H.; PARK, J.M.; LEE, J.Y.; JO, C.; BYUN, M.W. Biological and anti-microbial activity of irradiated green tea polyphenols. Food Chem., v. 88, p. 549-555, 2004.

8 - ANDERSON, R.A.; POLANSKY, M.M. Tea enhances insulin activity. J. Agric. Food Chem. v. 50, p. 7.182-7.186, 2002.

9 - ANJO, D.F.C. Alimentos funcionais em angiologia e cirurgia vascular. J. Vasc. Bras., v. 3, p. 145-54, 2004.

10 - AQUINO, S. Efeitos da radiação gama no crescimento de Aspergillus flavus produtor de aflatoxinas e no emprego da técnica da reação em cadeia de polimerase (PCR) em amostras de grãos de milho inoculadas artificialmente. 2003. Dissertação (Mestrado) - Instituto de Pesquisas Energéticas e Nucleares, São Paulo.

11 - AQUINO, S.; GONCALEZ, E.; REIS, T.A.; ARAÚJO, M.M.; CORREA, B.; VILLA VICENCIO, A.L.C.H. Evaluation of fungal burden of medicinal plants submitted to gamma radiation process after 30 days. In: International Nuclear Atlantic conference (INAC) - VIII ENAN, 2007, Santos, SP. International Nuclear Atlantic conference (INAC). 
12 - ARAÚJO, M.M.; MARIN-HUACHACA, N.S.; MANCINI-FILHO, J.; DELINCÉE, H.; VILLAVICENCIO, A.L.C.H. Identification of irradiated refrigerated pork with the DNA comet assay. Radiat. Phys. Chem., v. 71, p. 183-185, 2004.

13 - AZIZ, N.H.; FOULY, M.Z.E M.; ABU-SHADY, R.; MOUSSA, L.A.A. Effect of gamma radiation on the survival of fungal and actinomycetal florae contaminating medicinal plants. Appl. Radiat. Isot., v. 48, p.71-76, 1997.

14 - AZNAR, M.; LOPEZ, R.; CACHO, J.F.; FERREIRA, V. Identification and quantification of impact odorants of aged red wines from Rioja - GC-olfactometry, quantitative GC-MS, and odor evaluation of HPLC fractions. J. Agric. Food Chem., v. 49, p. 2924-2929, 2001.

15 - BALENTINE, D.A.; WISEMAN, S.A.; BOUWENS, L.C. The chemistry of tea flavonoids. Rev. Food Sci. Nutr., v. 37, p. 693-704, 1997.

16 - BECKER, E.M.; NISSEN, L.R.; SKIBSTED, L.H. Antioxidante evaluation protocols: food quality or health effects. Europ. Food Res. Techn., v. 219, p. 561$571,2004$.

17 - BENT, S.; KO, R. Commonly used herbal medicines in the United States: a review. Am. J. Med., v. 116, p. 478-485, 2004.

18 - BERGER, R.G.; DRAWERT, F.; KOLLMANNSBERGER, H. The "flavor" of cape gooseberry (Physalis peruviana L.). Z. Lebensm. Unters. Forsch, v. 188, p. 122126, 1989.

19 - BHATTACHARYYA, N.; SETH, S.; TUDU, B.; TAMULY, P.; JANA, A.; GHOSH, D.; BANDYOPADHYAY, R.; BHUYAND, M.; SABHAPANDIT, S. Detection of optimum fermentation time for black tea manufacturing using electronic nose. Sensors and Actuators B, v. 122, p. 627-634, 2007.

20 - BIANCHI, M.L.P.; ANTUNES, L.M.G. Radicais livres e os principais antioxidantes da dieta. Rev. Nutr., v. 12, n. 2, p. 123-130, 1999.

21 - BLANK, I.; FISCHER, K.H.; GROSCH, W. Intensive neutral odourants of linden honey: differences from honeys of other botanical origin. Z. Lebensm. Unters. Forsch, v. 189, p. 426-433, 1989.

22 - BLANK, I.; GROSCH, W. Evaluation of potent odorants in dill seed and dill herb (Anethum graveolens L.) by aroma extract dilution analysis. J. Food Sci., v. 56, p. 63-67, 1991.

23 - BLANK, I.; SEN, A.; GROSCH, W. Potent odorants of the roasted powder and brew of Arabica coffee. Z. Lebensm. Unters. Forsch, v. 195, p. 239-245, 1992.

24 - BORGES, V.C. Alimentos funcionais: prebióticos, probióticos, fitoquímicos e simbióticos. In: WAITZBERG, D.L. Nutrição enteral e parenteral na prática clínica. São Paulo: Atheneu, 2001. 
25 - BORSE, B.B.; RAO, L.J.M.; NAGALAKSHMI, S.; KRISHNAMURTHY, N. Fingerprint of black teas from India: identification of the regio-specific characteristics. Food Chem., v. 79, p. 419-424, 2002.

26 - BRAITHWAITE, A.; SMITH, F.J. Chromatographic methods. 5.ed., Glasgow: Chapman \& Hall, 1996.

27 - BRASIL. Regulamento Técnico de Espécies Vegetais para o Preparo de Chás. Resolução de Diretoria Colegiada - RDC n. 267, 2005.

28 - BRASIL. Regulamento técnico para irradiação de alimentos. Resolução de Diretoria Colegiada - RDC n. 21, 2001.

29 - BUGNO, A.; BUZZO, A.A.; NAKAMURA, C.T.; PEREIRA, T.C.; MATOS, D.; PINTO, T.J.A. Avaliação da contaminação microbiana em drogas vegetais. Rev. Bras. Ciênc. Farmac., v. 41, p. 491-497, 2005.

30 - CABRERA, C.; GIMENEZ, R.; LÓPEZ, M.C. Determina-tion of tea components with antioxidant activity. J. Agric. Food Chem., v. 51, p. 4.427-4.435, 2003.

31 - CALIXTO, J.B. Twenty-five years of research on medicinal plants in Latin America. A personal view. J. Ethnopharmacol., v. 100, p. 131-134, 2005.

32 - CASTELLANOS, F. X.; RAPOPORT, J. L. Effects of caffeine on development and behavior in infancy and childhood: a review of the published literature. Food Chem. Toxicol., v. 40, p. 1235-1242, 2002.

33 - CHENG, Y.; HUYNH-BA, T.; BLANK, I.; ROBERT, F. Temporal changes in aroma release of longjing tea infusion: interaction of volatile and nonvolatile tea components and formation of 2-butyl-2-octenal upon aging. J. Agric. Food Chem., v. 56, p. 2160-2169, 2008.

34 - CHISHOLM, M.G.; WILSON, M.A.; GASKEY, G.M. Characterization of aroma volatiles in key lime essential oils (Citrus aurantifolia). "flavor” Fragr. J., v. 18, p. 106-115, 2003.

35 - CHMIELEWSKI, A.G.; HAJI-SAEID, M. Radiation technologies: past, present and future. Radiat. Phys. Chem., v. 71, p. 17-21, 2004.

36 - CHO, J.Y.; MIZUTANI, M.; SHIMIZU, B.I.; KINOSHITA, T.; OGURA, M.; TOKORO, K.; LIN, M.L.; SAKATA, K. Chemical profiling and gene expression profiling during the manufacturing process of taiwan oolong tea 'Oriental Beauty'. Biosci. Biotechnol. Biochem., v. 71, p. 1476-1486, 2007.

37 - CHOI, H.S. Character impact odorants of citrus hallabong [(C. unshiu Marcov x $C$. sinensis Osbeck) x C. reticulata Blanco] cold-pressed peel oil. J. Agric. Food Chem., v. 51, p. 2687-2692, 2003.

38 - CHUNG, T.Y.; EISERICH, J.P.; SHIBAMOTO, T. Volatile compounds isolated from edible Korean chamchwi (Aster scaber Thunb). J. Agric. Food Chem., v. 41, p. 1693-1697, 1993. 
39 - CNEN - Comissão Nacional de Energia Nuclear. Aplicações da energia nuclear. Disponível em: < http://www.cnen.gov.br/ensino/apostilas/aplica.pdf >. Acesso em: 15 jan. $2009 \mathrm{~b}$.

40 - CNEN - Comissão Nacional de Energia Nuclear. Radiações ionizantes e a vida. Disponível em: <http://www.cnen.gov.br/ensino/apostilas/rad_ion.pdf >. Acesso em: 15 jan. 2009a.

41 - CODEX ALIMENTARIUS COMMISSION. Codex general standard for irradiated foods. Codex Stan 106-1983. Rev. 1-2003, 2003.

42 - COLLINS, C.H. Princípios básicos de cromatografia. In: COLLINS C.H.; BRAGA, G.L.; BONATO, P.S. Fundamentos de cromatografia. Campinas: Editora da UNICAMP, 2006.

43 - CONSTANTIN, E.; SCHNELL, A. Mass spectrometry. Chichester: Ellis Horwood, 1990.

44 - DAVID, D.J. Gas chromatographic detectors. New York: John Wiley \& Sons, 1974.

45 - DAVIS, R.; FREARSON, M. Mass spectrometry. London: John Wiley \& Sons, 1987.

46 - DE MARIA, C.A.B.; MOREIRA, R.F.A. Cafeína: revisão de métodos de análise. Quim. Nova, v. 30, p. 99-105, 2007.

47 - DE SMET, P.A.G.M. Health risks of herbal remedies: an update. Clin. Pharmacol. Therm., v. 76, p. 1-17, 2004.

48 - DELINCÉE, H.; POOL-ZOBEL, B. L. Genotoxic properties of 2dodecylcyclobutanone, A compound formed on irradiation of food containing fat. Radiat. Phys. Chem., v. 52, p. 39-42, 1998.

49 - DIEHL, J. F. Safety of irradiated foods. New York: Marcel Deckker, 1995.

50 - DIEHL, J.F. Food irradiation - past, present and future. Radiat. Phys. Chem., v. 63, p. 211-215, 2002.

51 - DREOSTI, I.E.; WARGOVICH, M.J.; YANG, C.S. Inhibition of carcinogenesis by tea: the evidence from experimental studies. Crit. Rev. Food Sci. Nutr., v. 37, p. 761-770, 1997.

52 - DUFRESNE, C.J.; FARNWORTH, E.R. A review of latest research findings on the health promotion properties of tea. J. Nutr. Biochem., v. 12, p. 404-421, 2001.

53 - DULLOO, A.G.; DURET, C.; ROHRER, D.; GIRARDIER, L.; MENSI, N.; FATHI, M.; CHANTRE, P.; VANDERMANDER, J. Efficacy of a green tea extract rich in catechin polyphenols and caffeine in increasing 24-h energy expenditure and fat oxidation in humans. Am. J. Clin. Nutr., v. 70, p. 1040-1045, 1999. 
54 - DUTTA, R.; HINES, E.L.; GARDNER, J.W.; UDREA, D.D.; BOILOT, P. Nondestructive egg freshness determination: an electronic nose based approach. Meas. Sci.Technol., v. 14, p. 190-198, 2003a.

55 - DUTTA, R.; KASHWAN, K.R.; BHUYAN, M.; HINES, E.L.; GARDNER, J.W. Electronic nose based tea quality standardization. Neural Networks, v. 16, p. 847$853,2003 b$.

56 - EFUNTOYE, M.O. Fungi associated with herbal drug plants during storage. Mycophat., v.136, p. 115-118, 1996.

57 - ENGEL, E.; BATY, C.; LE CORRE, D.; SOUCHON, I.; MARTIN, N. "flavor"active compounds potentially implicated in cooked cauliflower acceptance. J. Agric. Food Chem., v. 50, p. 6459-6467, 2002.

58 - FANARO, G.B.; ARAÚJO, M.M.; THOMAZ, F.S.; DUARTE, R.C.; VILLAVICENCIO, A.L.C.H. Comparison of treatment in soybean grains between ${ }^{60} \mathrm{Co}$ and e-beams applications. In: International Nuclear Atlantic conference (INAC) - VIII ENAN, 2007, Santos, SP. International Nuclear Atlantic conference (INAC).

59 - FANARO, G.B.; SALUM D.C.; NUNES, T.C.F; FURGERI, C.; RELA, P.; VILLA VICENCIO, A.L.C.H. Advances between e-beams and ${ }^{60} \mathrm{Co}$ applications in soybean grains. In: Eight International Topical Meeting on Nuclear Applications and Utilization of Accelerators (AccApp'07), Pocatello, Estados Unidos da América, International Topical Meeting on Nuclear Applications and Utilization of Accelerators, p. 1022-1025, 2007b.

60 - FARKAS, J. Irradiation for better foods. Tren. Food Scien. Technol., v. 17, p. 148$152,2006$.

61 - FARKAS, J. Physical methods of food preservation. 2. ed., Washington: ASM, p. 567-591, 2001.

62 - FARMACOPÉIA BRASILEIRA: 4 ${ }^{\text {a }}$ Edição. São Paulo: Editora Atheneu, parte II, 4.fascículo, 2000.

63 - FARMACOPÉIA BRITÂNICA, v.II, Strasbourg: Council of Europe. 2000.

64 - FARMACOPÉIA EUROPÉIA, Strasbourg: Council of Europe Strasbourg: Council of Europe. S2001.

65 - FERRARA, L.; MONTESANO, D.; SENATORE, A. The distribution of minerals and flavonoids in the tea plant (Camellia sinensis). Il Farm., v. 56, p. 397-401, 2001.

66 - FERREIRA, V.; AZNAR, M.; LÓPEZ, R.; CACHO, J. Quantitative Gas Chromatography-Olfatometry Carried out at Different Dilutions of an Extract. Key Differences in the Odor Profiles of Four High-Quality Spanish Aged Red Wines. J. Agric. Food Chem., v. 49, p. 4818-4824, 2001.

67 - FINDLAY, D. J. S.; PARSON, T. V.; SENÉ, M. R. Irradiation of food and the induction of radioactivity. Radiat. Phys. Chem., v. 42, n. 1-3, p. 417-420, 1993. 
68 - “FLAVOR”NET. “flavor”net and human odor space. Disponível em: <http://www."flavor"net.org>. Acesso em 12 jan. 2009.

69 - FUHRMANN, E.; GROSCH, W. Character impact odorants of the apple cultivars Elstar and Cox orange. Nahrung., v. 46, p. 187-193, 2002.

70 - FURGERI, C.; SABUNDJIAN, I. T.; SILVA, P. V.; SALUM, D. C.; BASTOS, D. H. M.; VILLAVICENCIO, A. L. C. H. Evaluation of sensorial analisys in maté (Ilex paraguariensis) processed by gamma radiation. In: International Nuclear Atlantic conference (INAC) - VIII ENAN, 2007, Santos, SP. International Nuclear Atlantic conference (INAC).

71 - GALANTE, A.M.S. Pesquisa, desenvolvimento e caracterização de materiais dosimétricos para monitoramento em processos de irradiação com doses altas. 2003. Tese (Doutorado) - Instituto de Pesquisas Energéticas e Nucleares, São Paulo.

72 - GASSER, U.; GROSCH, W. Primary odorants of chicken broth. A comparative study with meat broths from cow and ox. Z. Lebensm. Unters. Forsch, v. 190, p. 38,1990 .

73 - GIVEON, S.M.; LIBERMAN, N.; KLANG, S.; KAHAN, E. Are people who use "natural drugs" aware of their potentially harmful side effects and reporting to family physician? Patient Educ. Couns., v. 53, p. 5-11, 2004.

74 - GOSSLAU, A.; CHEN, K.Y.; Nutraceuticals, Apoptosis, and Disease Prevention, Nutrition, v. 20, p. 95-101, 2004.

75 - GROB R.L. Theory of gas chromatography. In: GROB, R.L.; BARRY, E.F. Modern pratice of gas chromatography. 4.ed., New Jersey: John Wiley \& Sons, 2004.

76 - GROSS, J.H. Mass spectrometry. A textbook. 1.ed. Berlin: Springer, 2004.

77 - GUEN, S.L.; PROST, C.; DEMAIMAY, M. Characterization of odorant compounds of mussels (Mytilus edulis) according to their origin using gas chromatographyolfactometry and gas chromatography-mass spectrometry. J. Chrom. A, v. 896, p. 361-371, 2000.

78 - GUICHARD, H.; GUICHARD, E.; LANGLOIS, D.; ISSANCHOU, S.; ABBOTT, N. GC sniffing analysis: olfactive intensity measurement by two methods. $\mathbf{Z}$. Lebensm. Unters. Forsch, v. 201, p. 344-350, 1995.

79 - GULATI, A.; TAMANG, M.B.; RAVINDRANATH, S.D. Clonal variation in quality related biochemicals in Kangra tea [Camellia sinensis (L.) O. Kuntze]. J. Plant. Crops, v. 27, p. 175-178, 1999.

80 - GUTH, H.; GROSCH, W. A comparative study of the potent odorants of different virgin olive oils. Fat Sci. Technol., v. 93, p. 335-339, 1991.

81 - GYAWALI R.; SEO, H. Y.; LEE, H. J.; SONG, H. P.; KIM, D. H.; BYUN, M. W.; KIM, K.S. Effect of $\gamma$-irradiation on volatile compounds of dried Welsh onion (Allium fistulosum L.). Radiat. Phys. Chem., v.75, p.322-328, 2006. 
82 - HANSEN, J.M.; SHAFFER, H.L. Sterilization and preservation by radiation sterilization. In: Block, S.S. Disinfection sterilization and preservation. 5 ed. Philadelphia: Lippincott Willians \& Wilkins, p. 729-746, 2001.

83 - HATTORI, S.; TAKAGAKI, H.; FUJIMORI, T. Identi.cation of Volatile Compounds which Enhance Odor Notes in Japanese Green Tea using the OASIS (Original Aroma Simultaneously Input to the Sni\$ng port) method. Food Sci. Technol. Res., v. 11, p. 171-174, 2005.

84 - HAYES, D.J.; MURANO, E.A.; MURANO, P.S.; OLSON, D.G.; SAPP, S.G. Food Irradiation: A Sourcebook. 1 ed. [S.I]: Ames, 1995.

85 - IAEA. International Atomic Energy Agency - Food irradiation with emphasis on process control and acceptance in Asia. IAEA TEC.DOC-871, 2001.

86 - ICGFI. The development of X-ray machines for food irradiation. Vienna, Austria, 1995.

87 - IPEN. Instituto de Pesquisas Energéticas e Nucleares. Sobre o IPEN - Histórico, principais convênios e eventos técnicos. Disponível em:

<http://www.ipen.br/ipen_p/sobre-ipen/historico/historico-principaisconvenios.html>. Acesso em 20 ago. 2004.

88 - JAMES, J.E. Critical review of dietary caffeine and blood pressure: a relationship that should be taken more seriously. Psychosom. Med., v. 66, p. 63-71, 2004.

89 - JIROVETZ, L.; BUCHBAUER, G.; NGASSOUM, M.B.; GEISSLER, M. Aroma compound analysis of Piper nigrum and Piper guineense essential oils from Cameroon using solid-phase microextraction-gas chromatography, solid-phase microextraction-gas chromatography-mass spectrometry and olfactometry. $\mathbf{J}$. Chrom. A, v. 976, p. 265-275, 2002.

90 - JO, C.; SON, J.H.; LEE, H.J.; BYUN, M.W. Irradiation application for color removal and purification of green tea leaves extract. Radiat. Phys. Chem., v. 66, p. 179-184, 2003.

91 - JORDAN, M.J.; MARGARIA, C.A.; SHAW, P.E.; GOODNER, K. L. Volatile components and aroma active compounds in aqueous essence and fresh pink guava fruit puree (Psidium guajava L.) by GC-MS and multidimensional GC/GC-O. J. Agric. Food Chem., v. 51, p. 1421 1426, 2003.

92 - JORGENSEN, U.; HANSEN, M.; CHRISTENSEN, L.P.; JENSEN, K.; KAACK, K. Olfactory and quantitative analysis of aroma compounds in elder flower (Sambucus nigra L.) drink processed from five cultivars. J. Agric. Food Chem., v. 48, p. 23762383, 2000.

93 - KAWAI, K.; TSUNO, N. H.; KITAYAMA, J.; OKAJI, Y.; YAZAWA, K.; ASAKAGE, M.; HORI, N.; WATANABE, T.; TAKAHASHI, K.; NAGAWA, H. Epigallocatechin gallate, the main component of tea polyphenol, binds to CD4 and inter-feres with gp120 binding. J. Allergy Clin Immunol., v. 112, p. 951-957, 2003. 
94 - KEMSLEY, E.K. Win-Das. Chichester: John Wiley \& Sons, 1998.

95 - KIM, M. J.; YOOK, H. S.; BYUN, M. W. Effects of gamma irradiation on microbial contamination and extraction yields of Korean medicinal herbs. Radiat. Phys.

Chem., v. 57, p. 55-58, 2000.

96 - KOO, S. I.; NOH, S. K. Green tea as inhibitor of the intestinal absorption of lipids: potential mechanism for its lipid-lowering effect. J. Nutr. Bioch., v. 18, p. 179-183, 2007.

97 - KOSEKI, P. M.; VILLAVICENCIO A. L. C. H.; BRITO, M. S.; NAHME, L. C.; SEBASTIÃO, K. I.; RELA, P. R.; ALEMIDA-MURADIAN, L. B.; MANCINIFILHO, J.; FREITAS, P. C. D. Effects of irradiation in medicinal and eatable herbs. Radiat. Phys. Chem., v. 63, p. 681-684, 2002.

98 - KUMEA, T.; FURUTA, M.; TODORIKI, S.; UENOYAMA, N.; KOBAYASHI, Y. Status of food irradiation in the world. Radiat. Phys. Chem., Em fase de impressão, 2009.

99 - LIANZHONG, D.; SHIYUE, D.; YAN, Z.; YIXU, L.; SONGMEI, Z. A study on chemical composition of spices irradiated by electron beam. Radiat. Phys. Chem., v. 52 , p. $49-52,1998$.

100 - LOPEZ, R.; ORTIN, N.; PÉREZ-TRUJILLO, J.P.; CACHO, J.; FERREIRA, V. Impact odorants of different young white wines from the Canary Islands. J. Agric. Food Chem., v. 51, p. 3419-3425, 2003.

101 - LORENZI, H.; MATOS, F.J.A. Plantas medicinais no Brasil: nativas e exóticas cultivadas. Nova Odessa: Instituto Plantarum, 2002.

102 - LUNING, P.A.; RIJK,T; WICHERS, H.J.; ROOZEN, J.P. Gas chromatography,mass spectrometry, and sniffing port analyses of volatile compounds of fresh bell peppers (Capsicum annuиm) at different ripening stages. J. Agric. Food Chem., v. 42, p. 977-983, 1994.

103 - MACHADO, C. C. B.; BASTOS, D. H. M.; JANZANTTI, N. S.; FACANALI , R.; MARQUES, M. O. M.; FRANCO, M. R. B. Determinação do perfil de compostos voláteis e avaliação do sabor e aroma de bebidas produzidas a partir da erva-mate (Ilex paraguariensis). Quim. Nova, v. 30, p. 513-518, 2007.

104 - MANDEEL, Q.A. Fungal contamination of some imported spices. Mycopathology, v. 159, p. 291-298, 2005.

105 - MASEFIELD, J. Reflections on the evolution and current status of the radiation industry. Radiat. Phys. Chem., v. 71, p. 9-16, 2004.

106 - MASUCCI, J.A.; CALDWELL, G.W. Techniques for gas chromatography/mass spectrometry. In: GROB, R.L.; BARRY, E.F. Modern practice of gas chromatography. 4.ed., New Jersey: John Wiley \& Sons, 2004. 
107 - MATSUBARA, S.; RODRIGUEZ-AMAYA, D.B. Conteúdo de miricetina, quercetina e kaempferol em chás comercializados no Brasil. Ciênc. Tecnol. Aliment., v. 26, n. 2, p. 380-385, 2006a.

108 - MATSUBARA, S.; RODRIGUEZ-AMAYA, D.B. Teores de catequinas e teaflavinas em chás comercializados no Brasil. Ciênc. Tecnol. Aliment., v. 26, n. 2, p. 401-407, 2006b.

109 - MAU, J.L.; KO, P.T.; CHYAU, C.C. Aroma characterization and antioxidant activity of supercritical carbon dioxide extracts from Terminalia catappa leaves. Food Res. Intern., v. 36, p. 97-104, 2003.

110 - MIRANDA-LOPEZ, R.; LIBBEY, L.M.; WATSON, B.T.; MCDANIEL, M.R. Odor analysis of pinot noir wines from grapes of different maturities by a gas chromatography-olfactometry technique (osme). J. Food Sci., v. 57, p. 985-993, 1992.

111 - MOIO, L.; ETIEVHT, P.; LANGLOIS, D.; DEKIMPE, J.; ADDEO, F. Detection of powerful odorants in heated milk by the use of extract dilution sniffing analysis. J. Dairy Res., v. 61, p. 385-394, 1994.

112 - MOITA NETO, J.M.; MOITA, G.C. Uma introdução à análise exploratória de dados multivariados. Quim. Nova, v. 24, p. 467-469, 1998.

113 - MOLINS, R.A. (ed). Food irradiation: principles and applications. New York: Wiley-Interscience, 2001. 469 p.

114 - MONK, J. D.; BEUCHAT, L. R.; DOYLE, M. P. Irradiation inactivation of foodborne microrganisms. J. Food Protec., v. 58, p. 197-208, 1995.

115 - MOREHOUSE, M. Food irradiation: the treatment of foods with ionizing radiation. Food Test. Anal., v. 4, 1998.

116 - MORRISSEY, R.F.; HERRING, C.M. Radiation sterilization: past, present and future. Radiat. Phys. Chem., v. 63, p. 217-221, 2002.

117 - MUKHTAR, H.; AHMAD, N., Cancer chemoprevention: future holds in multiple agents. Toxicol. App. Pharm., v. 158, p. 207-210, 1999.

118 - NING, L.; YU, M.; CHUNHUI, D.; XIANGMIN, Z. Separation and identification of volatile constituents in Artemisia argyi flowers by GC-MS with SPME and steam distillation. J. Chrom. Sci., v. 46, p. 401-405, 2008.

119 - NISHIMURA, O. Identification of the characteristic odorants in fresh Rhizomes of ginger (Zingiber officinale Roscoe) using aroma extract dilution analysis and modified multidimensional gas chromatography-mass spectroscopy. J. Agric. Food Chem., v. 43, p. 2941-2945, 1995.

120 - NUNES, F.C.G. Avaliação microbiológica e toxigênica de chás e cápsulas usados como fitoterápico na cidade de São Paulo. 2003. Dissertação (Mestrado) - Escola Paulista de Medicina, São Paulo. 
121 - OLSON, D.G. Irradiation of food. Food Technol., v. 52, p. 56-62, 1998.

122 - ONG, P.K.C.; ACREE, T.E. Similarities in the aroma chemistry of gewuerztraminer variety wines and lychee (Litchi chinensis Sonn.) fruit. J. Agric. Food Chem., v. 47, p. 665-670, 1999.

123 - OWUOR, P.O.; OBANDA, M.; NYIRENDA, H.E.; MANDALA, W.L. Influence of region of production on clonal black tea chemical characteristics. Food Chem., v. 108, p. 263-271, 2008.

124 - PANIZZA, S. Plantas que curam: Cheiro de mato. 28.ed, São Paulo: Ibrasa, 1997.

125 - PEARCE, T.C.; GARDNER, J.W.; FRIEL, S.; BARTLETT, P.N.; BLAIR, N. Electronic nose for monitoring the "flavor" of beers. Analyst., v. 118, p. 371-377, 1993.

126 - PENNA, E.W.; ZUNIGA, M.J.; FUENZALIDA, R. Caracterización sensorial y química de la calidad de tés (Thea sinensis) consumidos em Chile. Arch.

Latinoamer. Nutric., v. 55, p. 93-100, 2005.

127 - POLLARD, E.C. Phenomenology of radiation effects on microorganisms. In: SPRINGER-VELAG (ed.) Encyclopedia of medical radiology. New york, 1966, v.2, p. 1-34.

128 - POLLONIO, M.A.R. Alimentos funcionais: as recentes tendências e os envolvidos no consumo. Higiene Alimentar, v. 14, p. 26-31, 2000.

129 - PRADO, C.C.; ALENCAR, R.G.; PAULA, J.R.; BARA, M.T.F. Avaliação do teor de polifenóis da Camellia sinensis (chá verde). Rev. Eletr. Farm., n. 2, supl., p. 164$167,2005$.

130 - RATES, S. M. K. Plants as source of drugs. Toxicon, v. 39, p. 603-613, 2001.

131 - RAVICHANDRAN, R. Carotenoid composition, distribution and degradation to "flavor" volatiles during black tea manufacture and the effect of carotenoid supplementation on tea quality and aroma. Food Chem., v. 78, p. 23-28, 2002.

132 - RAVICHANDRAN, R.; PARTHIBAN, R. Lipid occurrence, distribution and degradation to favour volatiles during tea processing. Food Chem., v. 68, p. 7-13, 2000.

133 - RAVICHANDRAN, R.; PARTHIBAN, R. The impact of processing techniques on tea volatiles. Food Chem., v. 62, n. 3, p. 347-353, 1998.

134 - RAWAT, R.; GULATI, A. Seasonal and clonal variations in some major glycosidic bound volatiles in Kangra tea (Camellia sinensis (L.) O. Kuntze). Eur. Food Res. Technol., v. 226, p. 1241-1249, 2008.

135 - RAWAT, R.; GULATI, A.; BABU, G.D.K; ACHARYA, R.; KAUL, V.K.; SINGH, B. Characterization of volatile components of Kangra orthodox black tea by gas chromatography-mass spectrometry. Food Chem., v. 105, p. 229-235, 2007. 
136 - ROSSI, A.M.; JESUS, E.F. A radiação que conserva. Ciência Hoje, v. 17, p. 24-29, 1994.

137 - RUSAK, T.; KOMES, D.; LIKIC, S.; HORZIC, D.; KOVAC, M. Phenolic content and antioxidative capacity of green and white tea extractsdepending on extraction conditions and the solvent used. Food Chem., v. 110, p. 852-858, 2008.

138 - RYCHLIK, M.; SCHIEBERLE, P.; GROSCH, W. Compilation of odor thresholds, odor qualities and retention indices of key food odorants. 1998. In: RYCHLIK, M.; BOSSET, J.O. "flavor" and off-"flavor" compounds of Swiss Gruyère cheese. Evaluation of potent odorants. Inter. Dairy J., v.11, 2001.

139 - SAITO, S.T.; WELZEL, A.; SUYENAGA, E.S., BUENO, F. A method for fast determination of epigallocatechin gallate (EGCG), epicatechin (EC), catechin (C) and caffeine (CAF) in green tea using HPLC. Ciênc. Tecnol. Aliment., v. 26, p. 394-400, 2006.

140 - SAKANAKA, S.; KIM, M.J.; YAMAMOTO, T. Antibacterial substances in Japanese green tea extract against Streptococcus mutans, a carciogenic bacterium. Agric. Bio. Chem., v. 53, p. 2307-2311, 1989.

141 - SALUM, D. C.; SABUNDJIAN, I. T.; SILVA, P. V.; FURGERI, C.; PURGATTO, E.; VILLAVICENCIO A. L. C. H. Sensorial effects of gamma radiation processing in cinamom (Laurus cinnamomum) and nut meg (Myristica fragans). In:

International Nuclear Atlantic conference (INAC) - VIII ENAN, 2007, Santos, SP. International Nuclear Atlantic conference (INAC).

142 - SANO, J.; INAMI S.; SEIMIYA, K., OHBA, T; SAKAI, S.; TAKANO, T.; MIZUNO, K. Effects of Green Tea Intake on the Development of Coronary Artery Disase, Circ J., v. 68, p. 665-70, 2004.

143 - SANTANA-RIOS, G.; ORNER, G.A.; AMANTANA, A.; PROVOST, C.; WU, S.Y.; DASHWOOD, R. H. Potent antimutagenic activity of white tea in comparison with green tea in the Salmonella assay. Mut. Res., v. 495, p. 61-74, 2001 a.

144 - SANTANA-RIOS, G.; ORNER, G.A.; XU, M.; IZQUIERDO-PULIDO, M.; DASHWOOD, R.H. Inhibition by white tea of 2-amino-1-methyl-6phenylimidazo[4,5- $b]$ pyridine-induced colonic aberrant crypts in the F344 rat. Nutrition and Cancer, v. 41, n. 1e2, p. 98-103, 2001 b.

145 - SATO,T.; MYATA, G. The Nutraceutical Benefit, Part I: Green tea. Nutrition, v. 16, p. 315-317, 2000.

146 - SCHIEBERLE, P. GROSCH, W. Evaluation of the "flavor" of wheat and rye bread crusts by aroma extract dilution analysis. Z. Lebensm. Unters. Forsch, v. 185, p. 111-113, 1987.

147 - SCHIEBERLE, P.; GROSCH, W. Identification of potent "flavor" compounds formed in an aqueous lemon oil/citric acid emulsion. J. Agric. Food Chem., v. 36, p. 797-800, 1988. 
148 - SCHNERMANN, P.; SCHIEBERLE, P. Evaluation of key odorants in milk chocolate and cacao mass by aroma extract dilution analyses. J. Agric. Food Chem., v. 45, p. $867-872,1997$.

149 - SEO, H.Y.; KIM, J.H.; SONG, H.P.; KIM, D.H.; BYUN, M.W.; KWON, J.H.; KIM, K.S. Effects of gamma irradiation on the yields of volatile extracts of Angelica gigas Nakai. Radiat. Phys. Chem., v. 76, p. 1869-1874, 2007.

150 - SIMÕES, C.M.O.; SCHENKEL, E.P.; GOSMANN, G.; MELLO, J.C.P.; MENTZ, L.A.; PETROVICK, P.R. Farmacognosia, da planta ao medicamento. 5.ed., Porto Alegre/Florianópolis: Editora da UFRGS/ Editora da UFSC, 2003.

151 - SMITH, A. Effects of caffeine on human behavior. Food Chem. Toxicol., v. 40, p. 1243-1255, 2002.

152 - SONAGLIO, D.; ORTEGA, G.G.; PETROVICK, P.R.; BASSANI, V.L. Desenvolvimento tecnológico e produção de fitoterápicos. In: SIMÕES, C.M.O.; SCHENKEL, E.P.; GOSMANN, G.; MELLO, J.C.P.; MENTZ, L.A.; PETROVICK, P.R. Farmacognosia, da planta ao medicamento. 5.ed., Porto Alegre/Florianópolis: Editora da UFRGS/ Editora da UFSC, 2003.

153 - SORIANI, R.R.; SATOMI, L.C.; PINTO, T.J.A.. Effects of ionizing radiation in ginkgo and guaraná. Technical note. Radiat. Phys. Chem., v. 73, p. 239-242, 2005.

154 - SUWANAGUL, A.; RICHARDSON, D.G. Identification of headspace volatile compounds from different pear (Pyrus communis L.) varieties. Acta Hortic., v. 475, p. 605-623, 1998.

155 - SUZUKI, M.; TABUCHI, M.; IKEDA, M.; UMEGAKI, K.; TOMITA, T. Protective effects of green tea cat-echins on cerebral ischemic damage. Med. Sci. Monit., v. 10, p. 166-74, 2004.

156 - TAKEO, T. Withering effect on the aroma formation found during oolong tea manufacturing. Agric. Biol. Chem., v. 48, p. 1083-1085, 1984.

157 - THOMAS, J.; SENTHILKUMAR, R.S.; KUMAR, R.R. MANDAL, A.K.A.; MURALEEDHARAN, N. Induction of $\gamma$ irradiation for decontamination and to increase the storage stability of black teas. Food Chem., v. 106, p. 180-184, 2008.

158 - TIJBURG, L.B.M.; MATTERN, T.; FOLTS, J.D. WEISGERBER, U.M.;Katan, M.B.Tea flavonoids and cardiovascular diseases: a review. Crit. Rev. Food Sci. Nutr., v. 37 p. 771-85, 1997.

159 - TOIT, R.; VOLSTEEDT, Y.; APOSTOLIDES, Z. Compa-rison of the antioxidant content of fruits, vegetables and teas measured as vitamin $C$ equivalents. Toxicology, v. 166, p. 63-69, 2001.

160 - TRITSCH, G. L. Food iradiation. Nutrition. v.16, nº 7/8, p. 698-701, 2000.

161 - ULLRICH, F.; GROSCH, W. Identification of the most intense odor compounds formed during autoxidation of methyl linolenate at room temperature. JAOCS. v. 65, p. $1313-1317,1988$. 
162 - ULLRICH, F.; GROSCH, W. Identification of the most intense volatile "flavor" compounds formed during autoxidation of linoleic acid. Z. Lebensm. Unters. Forsch, v. 184, p. 277-282, 1987.

163 - VILLA VICENCIO, A.L.C.H.; FANARO, G.B.; ARAÚJO, M.M.; AQUINO, S.; SILVA, P.V.; MANCINI-FILHO, J. Detection of Phakopsora pachyrhizi by polymerase chain reaction (PCR) and use of germination test and DNA comet assay after e-beam processing in soybean. Radiat. Phys. Chem., v. 76, p. 1878-1881, 2007.

164 - VILLA VICENCIO, A.L.C.H.; MANCINI-FILHO, J.; DELINCÉE, H. Application of a rapid screening method to detect irradiated meat in Brazil. Radiat. Phys. Chem., v. 57, p. 295-298, 2000.

165 - WAKEFORD, C. A.; BLACKBURN, R.; SWALLOW, A. J. Induction and detection of radioactivity in foodstuffs irradiated with $10 \mathrm{MeV}$ electrons and X-rays. Radiat. Phys. Chem., 1991.

166 - WANASUNDARA, U.N.; SHAHIDI, F. Antioxidative and prooxidant activity of green tea extract in marine oils. Food Chem., v. 63, p. 335-342, 1998.

167 - WANG, L.F.; LEE, J.Y.; CHUNG, J.O.; BAIK, J.H.; SO, S. PARK, S.K. Discrimination of teas with different degrees of fermentation by SPME-GC analysis of the characteristic volatile "flavor" compounds. Food Chem., v. 109, p. 196-206, 2008 .

168 - WATSON, J.T. Introduction to mass spectrometry. 3.ed., Philadelphia: Lippincott-Raven, 1997.

169 - WEISBURGUER, J.H. Tea and health: a historical perspective. Cancer Letters, v. 114, p.315-317, 1997.

170 - WHITE, F.A.; WOOD, G.M. Mass spectrometry. New York: John Wiley \& Sons, 1986.

171 - WHO - World Health Organization. Safty and nutritional adequacy of irradiated food. Geneva, 1994.

172 - WHO. World Helth Organization. High-dose irradiation: wholesomeness of food irradiated with doses above 10 kGy. Techinical Report Series 890, Geneva, 1999.

173 - WIDDER, S.; SEN, A.; GROSCH, W. Changes in the "flavor" of butter oil during storage. Identification of potent odorants. Z. Lebensm. Unters. Forsch, v. 193, p. 32-35, 1991.

174 - WILLET, J. Gas chromatographic. New York: John Wiley \& Sons, 1993.

175 - WOODS, R. J.; PIKAEV, A. K. Applied Radiation Chemistry: Radiation Processing. New York, USA, 1994.

176 - YAMAGUCHI, K.; SHIBAMOTO, T. Volatile Constituents of Green Tea, Gyokuro (Camellia sinensis L. var Yabukita). J. Agric. Food Chem., v. 29, p. 366-370, 1981. 
177 - YANG, C. S; CHUNG, J. Y.; YANG, G.; CHHABRA, S. K.; LEE, M. J. Tea and tea polyphenols in cancer prevention. J. Nutr., v. 130, p. 472S-478S, 2000.

178 - YEO, S.G.; AHN, C.W.; LEE, Y.W.; LEE, T.G.; PARK, Y. H.; KIM, S.B. Antioxidative effect of tea extracts from green tea, oolong tea and black tea. J. Korean Soc. Food Sci. Nutr., 24, 229-304, 1995.

179 - YONG, L.F.M.; ACREE, T.E.; LAVIN, E.H.; BUTTS, R.M. Aroma chemistry of crackers. In: PARLIMENT, T. H., MCGORRIN, R. J., HO, C.T. (Eds). Thermal Generation of Aromas. American Chemistry Society: Washington, 1989.

180 - YU, Y.B., JO, S.K. Evaluation on the safety of g-irradiated Angelica gigas Nakai: stability of active components and safety in genotoxicity test. J. Korean Soc. Food Sci. Nutr., v. 29, p. 300-306, 2000.

181 - YU, Y.B.; JEONG, I.Y.; PARK, H.R.; OH, H.; JUNG, U.; JO, S.K. Toxicological safety and stability of the components of an irradiated Korean medicinal herb, Paeoniae Radix. Radiat. Phys. Chem., v. 71, p. 115-119, 2004. 